
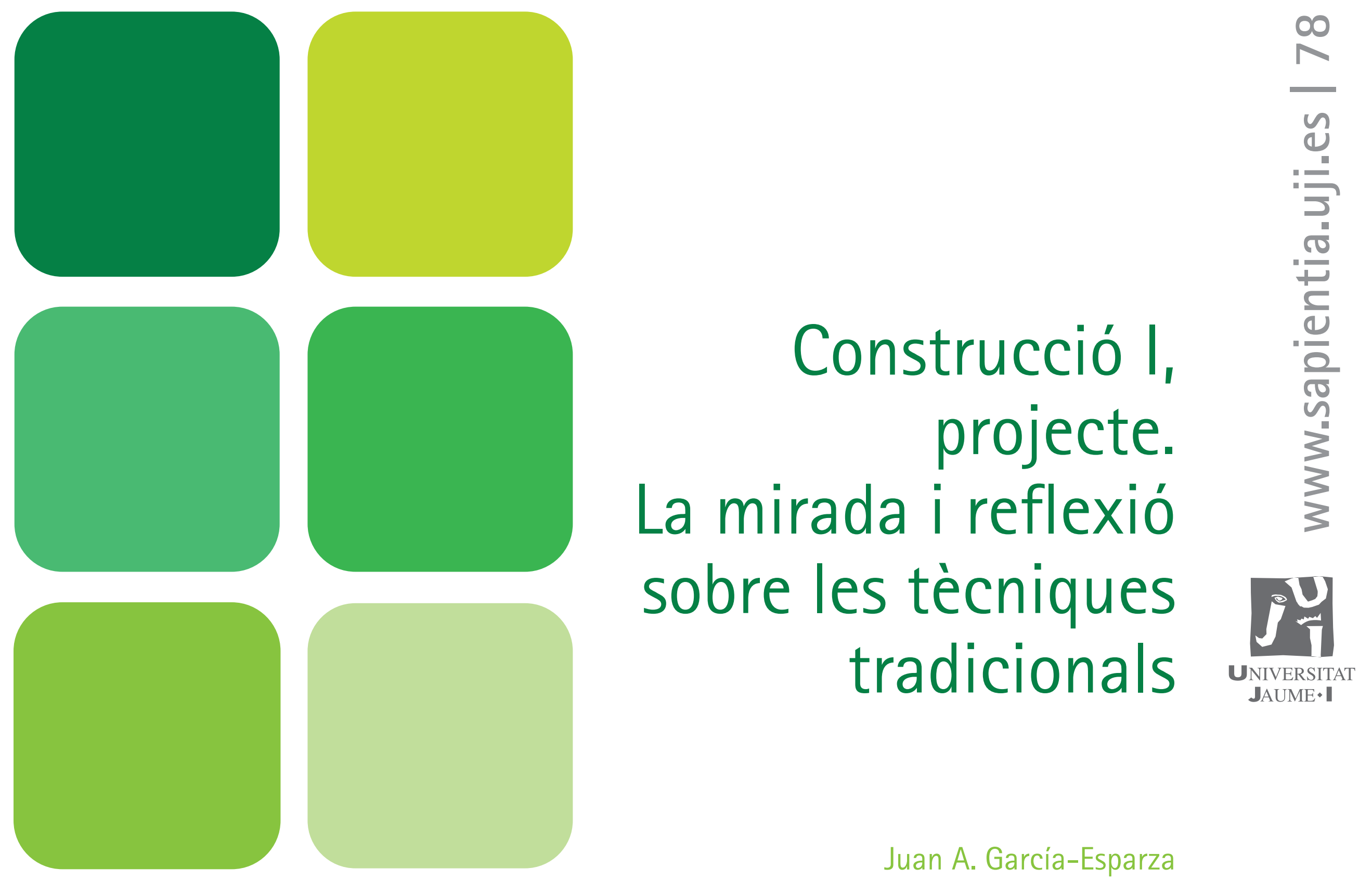


\section{Construcció I, projecte. La mirada i reflexió sobre les tècniques tradicionals}

Juan A. Garcia-Esparza

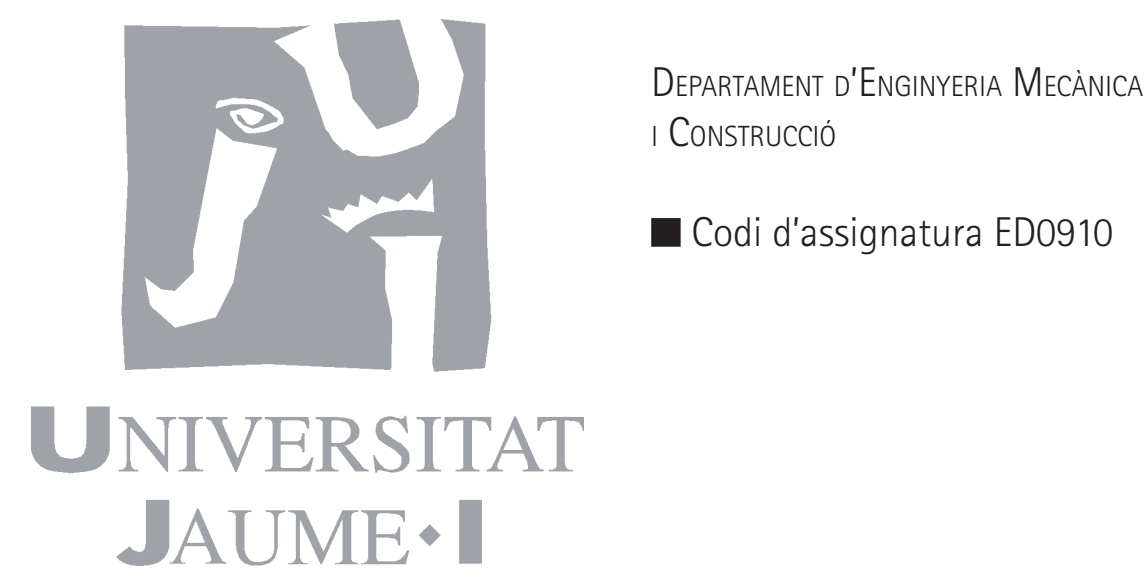


Edita: Publicacions de la Universitat Jaume I. Servei de Comunicació i Publicacions Campus del Riu Sec. Edifici Rectorat i Serveis Centrals. 12071 Castelló de la Plana http://www.tenda.uji.es e-mail: publicacions@uji.es

\section{(C) Del text: Juan A. García-Esparza, 2013}

(C) De les imatges: els alumnes i les alumnes, 2013

Revisió dels textos: Fermín Font Mezquita

Col·lecció Sapientia 78, http://repositori.uji.es/xmlui/handle/10234/67440

Col·lecció Sapientia 79, http://hdl.handle.net/10234/67460

Col·lecció Sapientia 80, http://repositori.uji.es/xmlui/handle/10234/67461

www.sapientia.uji.es

Primera edició, 2013

\section{ISBN: 978-84-695-8048-6}

Publicacions de la Universitat Jaume I és una editorial membre de l'UNE cosa que en garanteix la difusió de les obres en els àmbits nacional i

U cosa que en garanteix la

\section{(c) (1) (2)}

Reconeixement-CompartirIgual

CC BY-SA

Aquest text està subjecte a una llicència Reconeixement-CompartirIgual de Creative Commons, que permet copiar, distribuir i comunicar públicament l'obra sempre que s'especifique l'autor i el nom de la publicació fins i tot amb objectius comercials i també permet crear obres derivades, sempre que siguen distribuïdes amb aquesta mateixa llicència.

http://creativecommons.org/licenses/by-sa/3.0/legalcode 


\section{Índex}

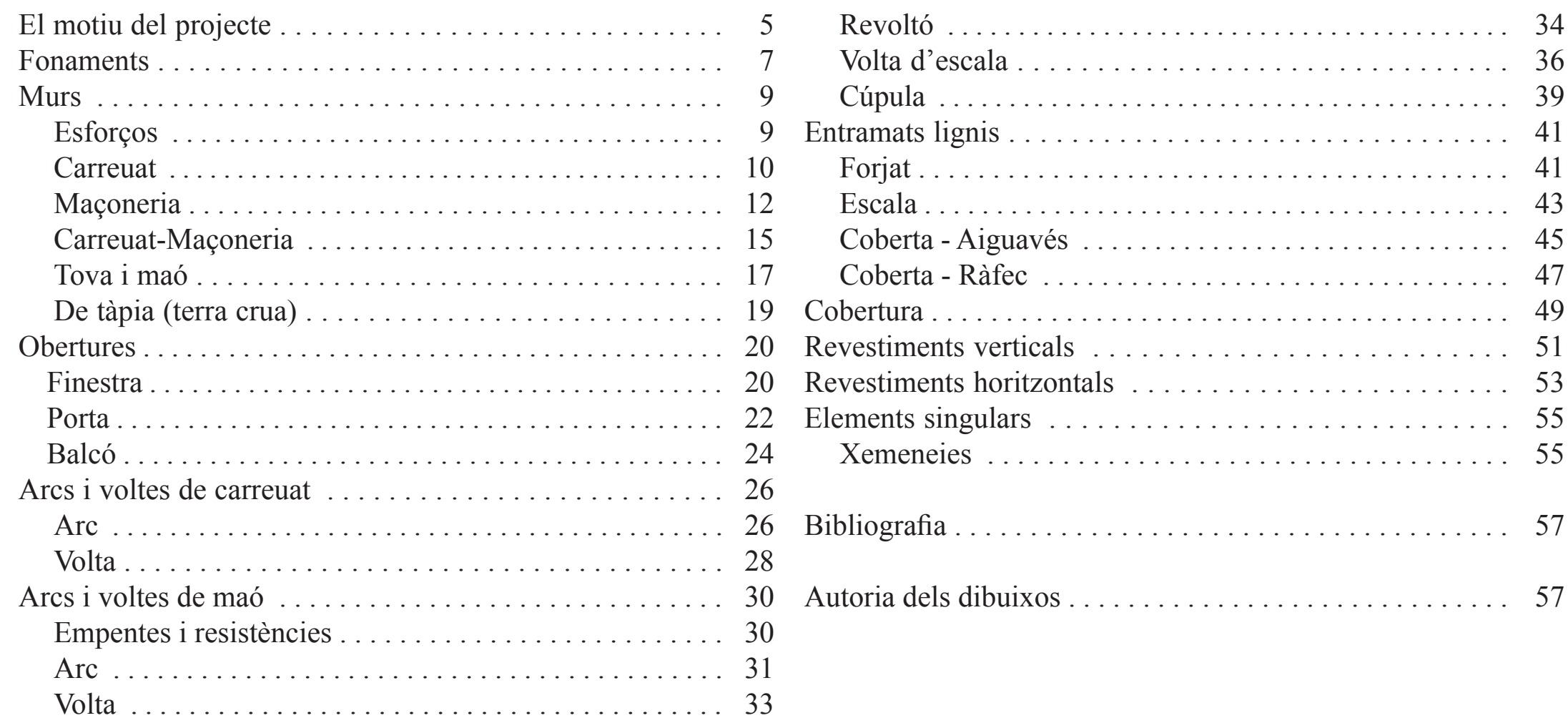




\section{El motiu del projecte}

Bona part del patrimoni edificat a l'àmbit rural està greument amenaçat, siga per abandonament, per la pressió immobiliària o per reformes que delaten el refús a l'habitatge tradicional, entre altres motius.

Vora un $60 \%$ dels enclaus històrics es troben amb problemàtiques comunes; pèrdua demogràfica, envelliment de la població, desocupació d'habitatges i mal estat $i$ inadequació d'aquests. La conseqüència és una patent regressió de nombrosos enclaus, i es considera que prop de les tres quartes parts es troba en situació de desemparament.

Per a l'anàlisi de la construcció tradicional mitjançant el Projecte Dirigit (PD), es pot emprar el terme enclau en un sentit ampli amb el qual aglutinar la denominació dels diferents assentaments, quasi sempre agrupats, encara que en ocasions es puga analitzar alguna edificació aïllada. Enclau significa doncs, el conjunt arquitectònic -urbà i rural-incloent-hi qualsevol habitacle o construcció disseminada, vinculat a una manera de viure o una tradició constructiva local, i per això, relacionat amb el paisatge cultural.

Els enclaus seleccionats amb motiu del PD son significatius de la regió que es pretén analitzar per posar en relleu les qualitats i capacitats d'aglutinar i presentar els trets d'una construcció tradicional com a mostra de la riquesa cultural, tant pel seu valor patrimonial com per la seua varietat tipològica.
La tipologia d'habitatge estudiada correspon especialment a una casa compacta i evolutiva. Un habitacle que reunia espais especialitzats diferenciats entre animals i persones, tant per als treballs del camp com per a la vida en família; un conjunt que reunia funcions productives i residencials.

La casa compacta ens mostra un volum únic edificat, la major part d'ocasions, sobre un terreny accidentat. Sorgeix d'una unitat constructiva elemental sobre la qual es van anar afegint volums, en altura normalment quan és agrupada $i$ en planta en els habitatges aïllats. La casa passa de ser un simple aixopluc residencial a aglutinar diverses funcions.

La tipologia edificatòria més comuna de les cases agrupades és la de planta baixa més dues altures $i$ àdhuc tres. Condicionant el nombre de plantes la manca de sòl i el pendent del terreny.

Estructuralment, la solució habitual és la de murs de càrrega sobre els quals descansen els nervis dels forjats, normalment de fusta, amb diferents solucions d'entrebigats, i l'estructura de la coberta, amb els elements que la conformen. També hi podem trobar diferents solucions de voltes formant els sostres de caves, plantes de soterranis o plantes baixes, la majoria construïdes amb pedra de paredar, rajoles i diversos tipus d'argamasses com a material d'unió. Els arcs apuntats o de diafragma, amb missió de suport de forjats, són també habituals, per a aconseguir, en espais de llums curtes, àmbits més diàfans. 
En la construcció tradicional és habitual el revestiment dels paraments, sobretot de les façanes, per a preservar els materials estructurals (pedres, maons, toves i argamassa) de l'acció erosiva de l'aigua. El material de revestiment més emprat és el morter de calç, el guix també ha estat emprat, però amb menys freqüencia, $\mathrm{i}$ en algunes zones on hi ha hagut tradició de construir amb terra, el fang. Els enrajolats ceràmics tan sols han estat emprats en zones del litoral, en habitatges exposats a l'ambient marí. Solament les façanes posteriors i les mitgeres dels habitatges podien estar exemptes de revestiments, així com les construccions auxiliars. 


\section{Fonaments}

El fonament és l'element que permet transmetre les càrregues que suporta una estructura al sòl, de manera que no sobrepasse la capacitat portant de terreny, i que les seues deformacions siguen admissibles per a l'estructura.

Els fonaments dels edificis històrics, quasi sempre superficials, es resolien normalment amb una secció genèrica que començava amb l'abocamen d'una primera capa de morter de calç aèria. Aquesta complia una funció semblant a la de l'actual formigó de neteja, protegint també les capes superiors de pedra calcària, susceptible de ser atacada per microorganismes $i$ substàncies de caràcter àcid pròpies del terreny.

Quan no era possible trobar un sol consistent, s'estenia una capa de preparació a base de reble amb morter de calç com a base de fonamentació.

El disseny de les sabates contínues (la solució habitual en la construcció tradicional), es realitzava per tempteig, determinant la pressió d'enfonsament, la pressió de treball o admissible i el càlcul dels assentaments esperables.

Les lesions en els fonaments dependran, entre altres factors, de la tipologia estructural de l'edifici i de les característiques del terreny. Aquestes poden ser de diversos tipus: enfonsament per rotura general -càrrega ràpida $i$ assentament del terreny-, per punxonament -sòls compressibles i poc resistents-, o per fractura local -plastifica el terreny en les vores de la sabata.
També poden produir-se greus assentaments diferencials de forma instantània per consolidació o per fluència lenta. Els orígens de les lesions solen trobar-se, entre altres causes, en el desconeixement del comportament del sòl, en les filtracions d'aigua o per errors de càlcul. En general, la roca és el millor sòl per a fonamentar, ja que la majoria n'asseguren una pressió de treball suficient per a un edifici tradicional $\left(\geq 3 \mathrm{kp} / \mathrm{cm}^{2}\right)\left(0,03 \mathrm{~N} / \mathrm{mm}^{2}\right)$. 


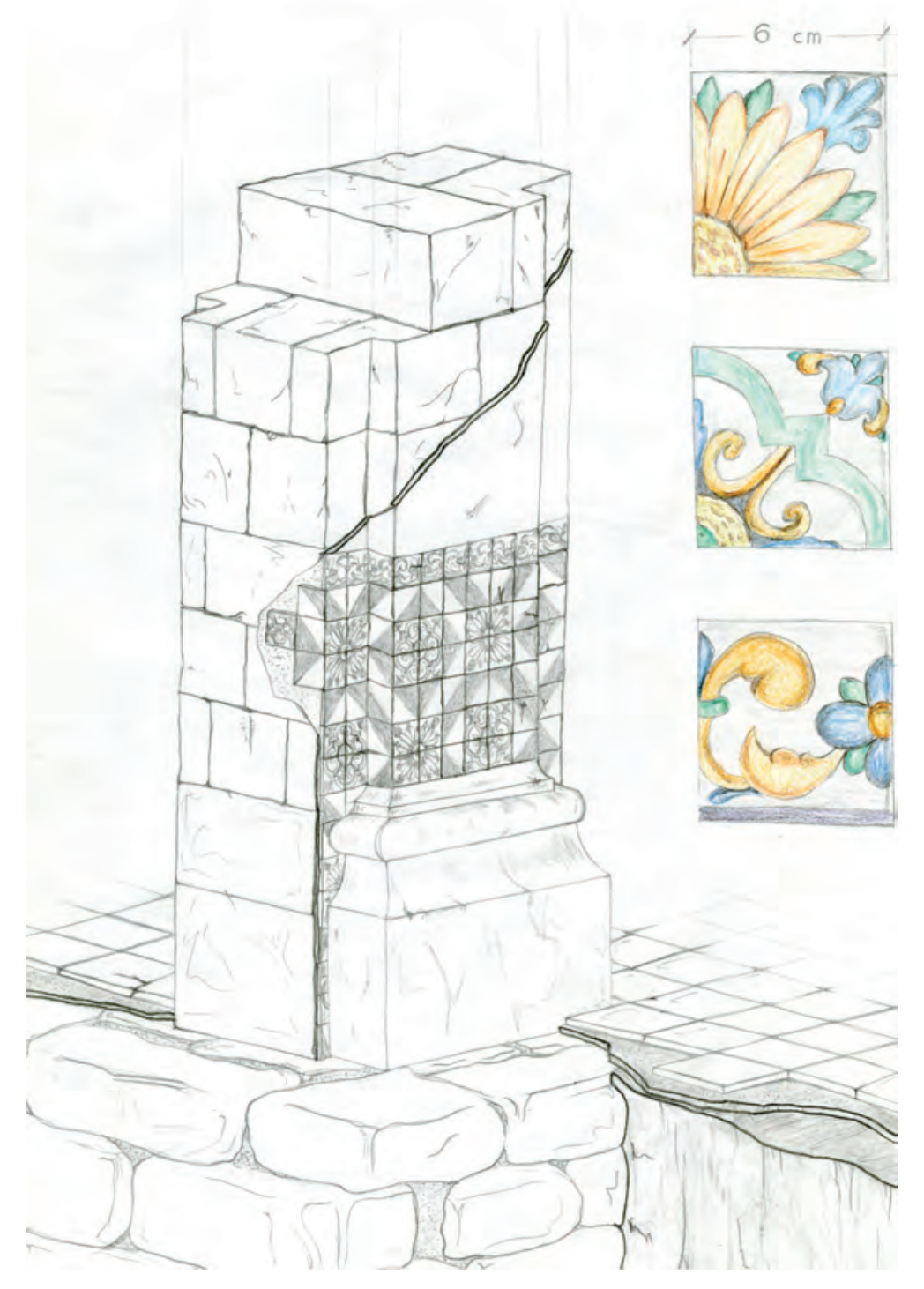

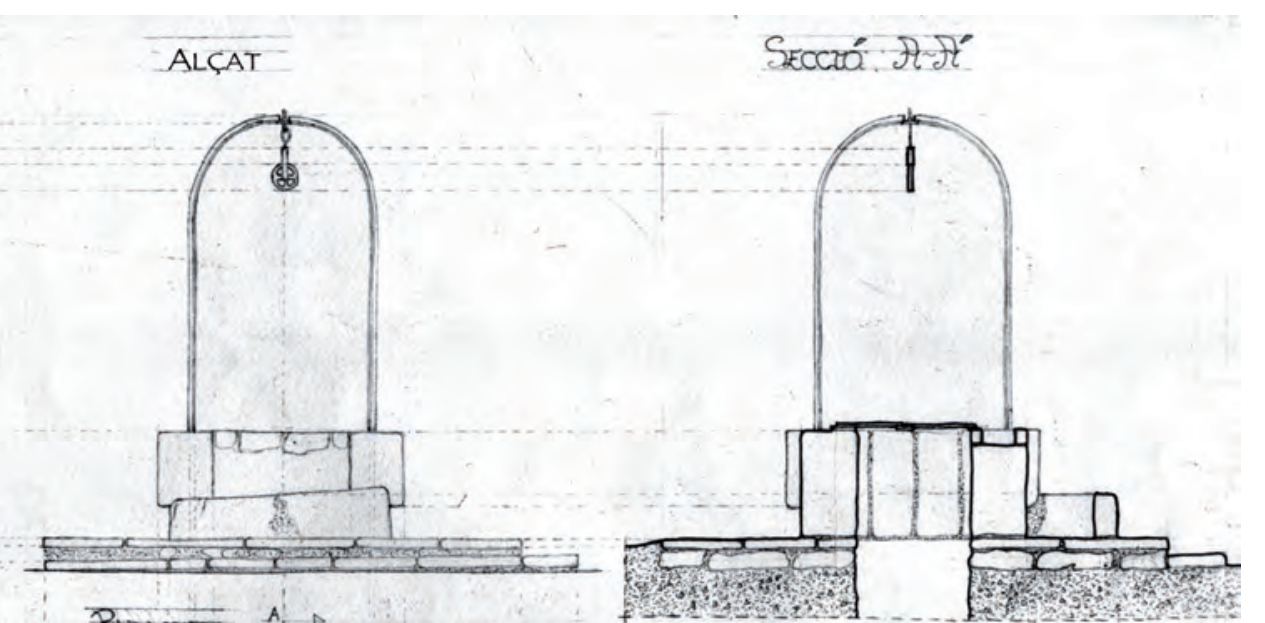
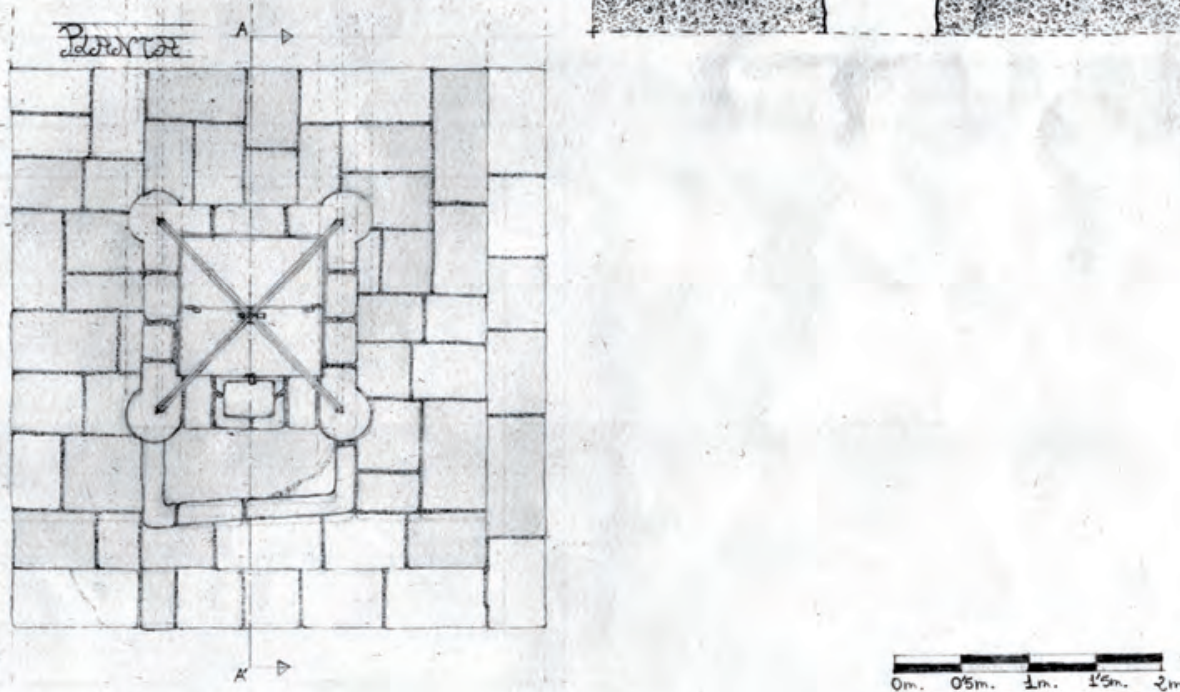

Escala apróx. 1.36 

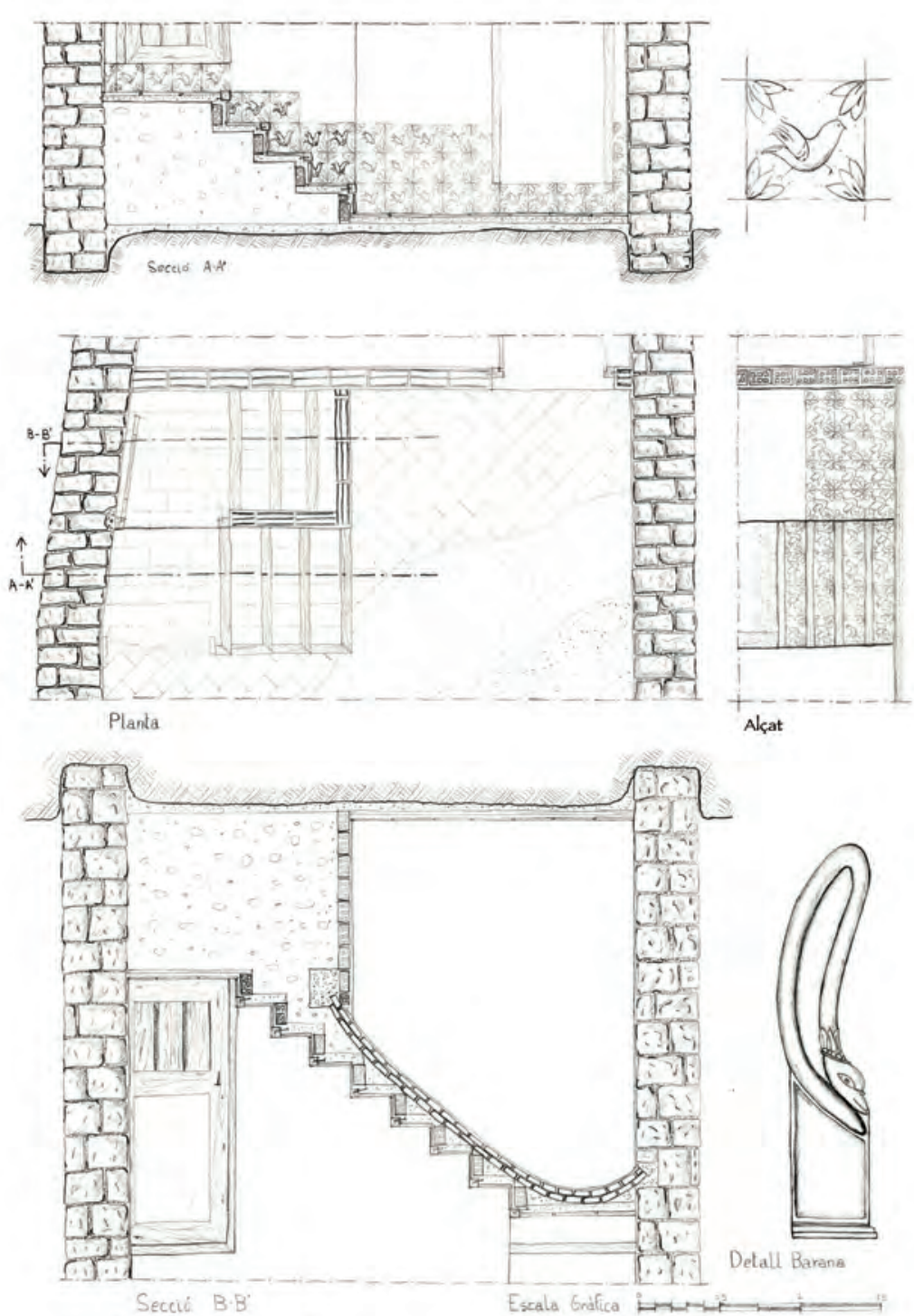

\section{Murs}

\section{Esforços}

En les construccions tradicionals els murs són elements que tenen per missió, entre altres, suportar el pes de l'estructura i transmetre-la als fonaments.

Poden fer-se de diversos materials com ara pedra, maons, toves, terra atapeïda, així com de materials resistents, units o no, per aglomerants com el morter de calç, de guix o terra argilosa pastada. L'elecció del material depén de molts factors: proximitat, resistència, durabilitat, facilitat d'execució, coneixement del material, etc.

Al segle XIX es realitzaren alguns assajos per a conèixer la influència de les juntes en la resistència de les fàbriques. Els enginyers empraren una regla simple: la resistència de la fäbrica és d' $1 / 10$ respecte a la resistència de ruptura a compressió de la pedra que la compon. Correctament disposades les pedres i travades, la resultant dels esforços a compressió és major en l'eix del mur.

La resistència de les fäbriques de maons depén del seu tipus i de la qualitat, del morter emprat, de la grossària de les juntes, i sobretot del correcte aparellament de les peces.

La resistència de les fàbriques de formigó o de tàpia ( tècniques diametralment diferents a les abans esmentades) dependrà de la correcta posada en obra del material, però també, i en gran mesura, de la qualitat i idoneïtat del material emprat. 
En les fàbriques construïdes amb la tècnica de l'addició, la resistència a tracció de les fàbriques depén de l'adherència entre el morter i les peces, maons o pedres, que no sol ser gaire elevada. El que veritablement impedeix el lliscament és el fregament entre les pedres i una adequada disposició de les peces.

El professor Heyman sistematitzà aquestes afirmacions per formar els principis de l'anàlisi límit de les fäbriques:

- La fäbrica té una resistència a compressió infinita.

- La fàbrica no té resistència a tracció.

- La fallada per lliscament és impossible.

\section{Carreuat}

El carreu én una pedra tallada en forma de paral·lelepípede rectàngle, que forma part d'una construcció de carreuat. En aquestes fàbriques els carreus van aparellats conformant allò que es considera com a elements quasi esculturals, on es valora sobretot el treball de la talla, el seu aparell i la qualitat de la pedra emprada. Els murs de pedra picada es poden executar sense morter d'unió, en sec, encara que en la majoria de fäbriques es fa ús d'un morter de calç de consistència fluida per a facilitar l'assentament dels carreus.

Per a la construcció de murs de pedra picada s'han emprat diferents tipus de pedra, segons la pedrera, i diferents tipus d'aparells, segons l'epoca i la qualitat de l'edifici. El mur es podia resoldre amb un interior completament massís, o bé amb l'interior buit o farcit amb reble i morter de calç, reduint-se considerablement, en aquests darrers dos casos, el pes de la fàbrica i el material a emprar.

En molts casos podem trobar murs de diversos fulls. En edificacions monumentals és habitual la solució d'un full exterior de carreuat i un d'interior de carreuó o de pedra de paredar. Les propietats mecàniques d'aquests murs són semblants però més econòmics que els d'un sol full de carreuat.

Els murs de pedra picada s'han de resoldre correctament per a suportar els esforços verticals i els eventuals esforços horitzontals. Enfront dels esforços verticals -de compressió- és fonamental un bon aparell i si és de diversos fulls, aquests han de travar-se òptimament. Enfront dels esforços horitzontals - de tracció o sisme- les peces s'uniran amb claus o grapes i ancorats als elements lignis o metàl-lics dels forjats i cobertes i, fins i tot, als edficis adjacents. 
DETALL FACANA PRINCIPAL

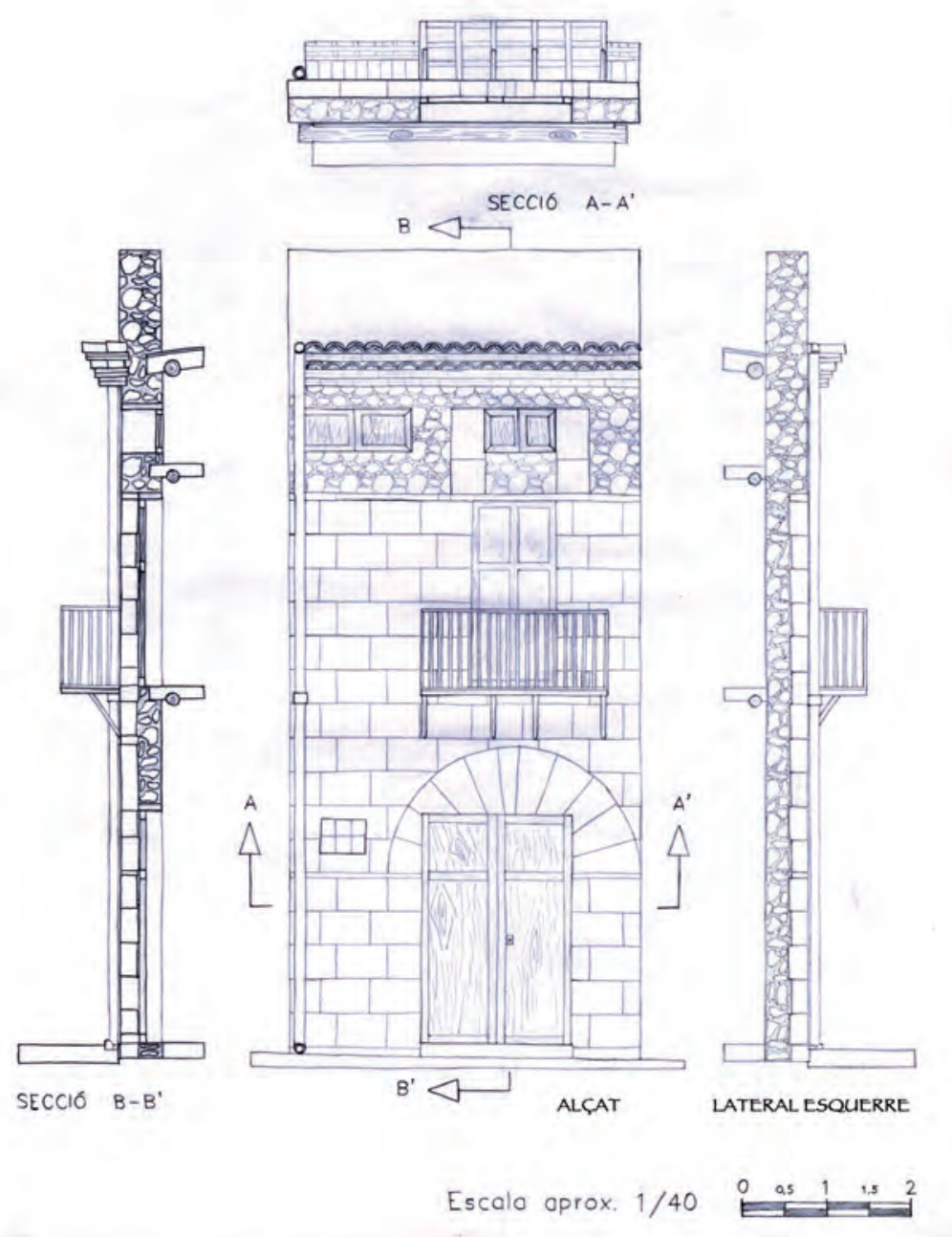

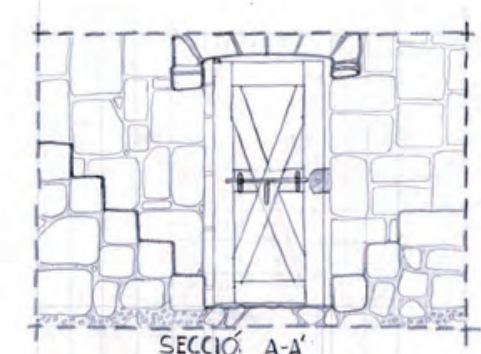

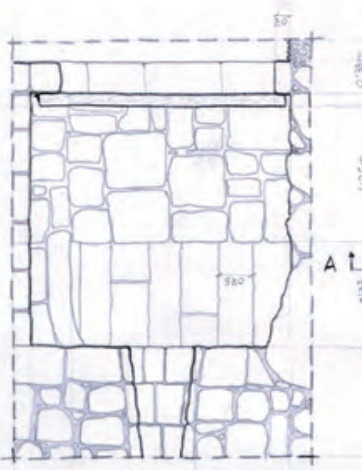

SECCIÓ B-B'
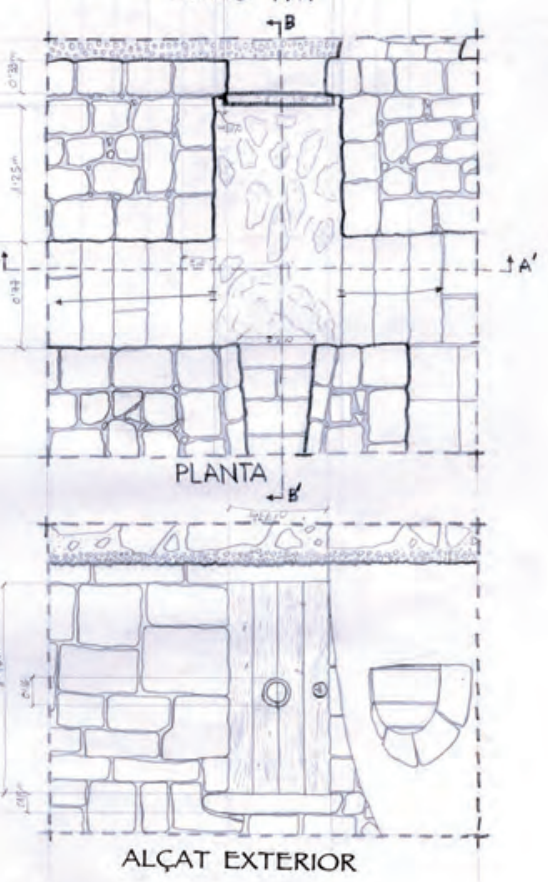


\section{Maçoneria}

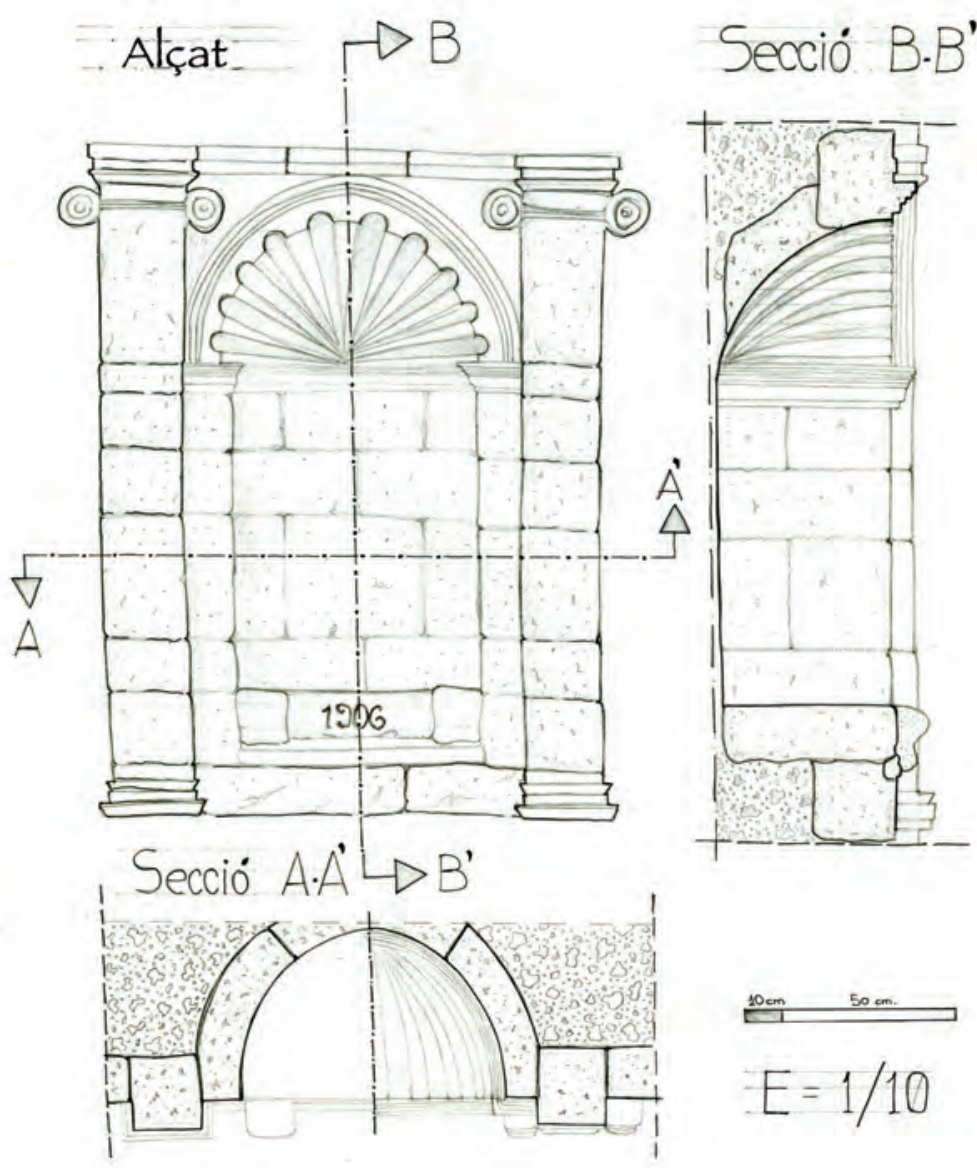

L'obra de maçoneria és la que es fa amb pedra de paredar amb la tècnica de l'addició, en la qual les peces és col-loquen ajustades, les unes amb les altres, amb qualsevol tipus d'argamassa o en sec en diversos ordres de filades i mides.

És el tipus de fàbrica més habitual, en la qual, segons la qualitat de la pedra i de l'edificació, les pedres rebran una major o menor preparació. Les mides i els tipus de les pedres aportaran una considerable varietat d'aspectes als seus paraments. Les pedres de paredar poden tenir una gran diversitat de formes, depenent, no solament de la seua preparació sinó també de la seua procedència. Les provinents de l'acció de despedregar camps seran, en general, amorfes i d'altres, arrodonides per l'efecte dels rierols i n'hi haurà de pseudoprismàtiques, si procedeixen d'una pedrera. Hi ha per tant, diversos tipus de fäbriques -ordinària, escairada i concertada-, de la més corrent fins a la que presenta un major treball de preparació de les pedres.

Totes les fàbriques requeriran de pedres de mida petita (el que s'anomena reble) per a assentar i subjectar les pedres. Les fàbriques fetes per mans menys expertes substitueixen, parcialment o completament, el reble per una bona quantitat de morter.

Els murs de maçoneria tenen normalment una missió de suport, amb gruixos d'uns $45 \mathrm{~cm}$ (equivalent a l'antiga mida de dos pams valencians). En edificacions monumentals (esglésies, castells, etc.), l'amplària dels murs sol ser considerablement més grossa.

El morter més emprat ha estat el de calç, i en ocasions el de guix o simplement fang argilós al qual, en ocasions, se li afegia guix per a accelerar l'enduriment.

La tècnica de la pedra en sec, o de la pedra seca, és aquella en què no s'utilitza cap tipus de morter per a unir les pedres. Ha estat molt emprada 
en el món rural d'algunes regions, sobretot en les construccions auxiliars. Aquesta tècnica exigeix un gran domini de l'ofici si es vol aconseguir una edificació sòlida i durable.
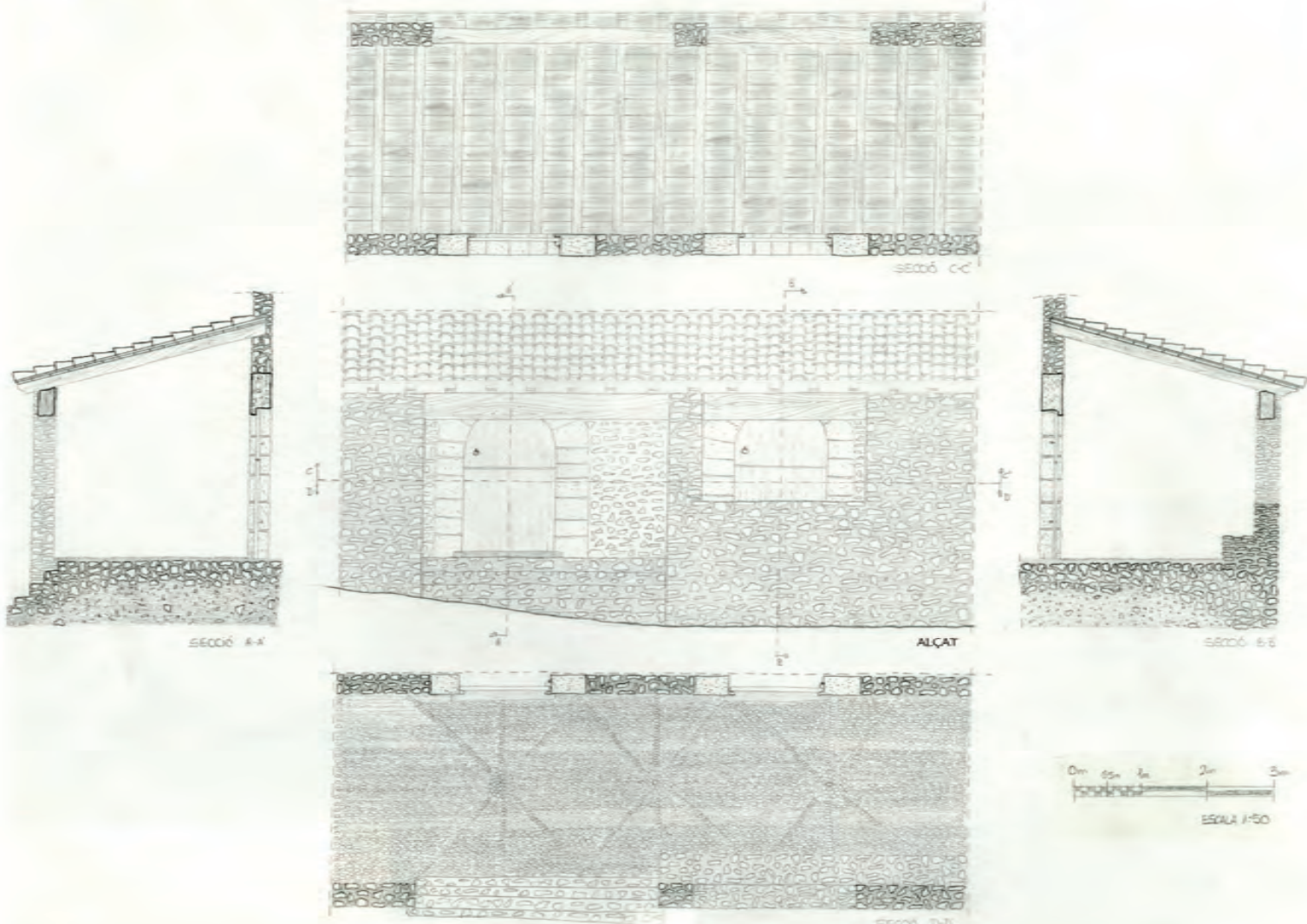

arbicis 

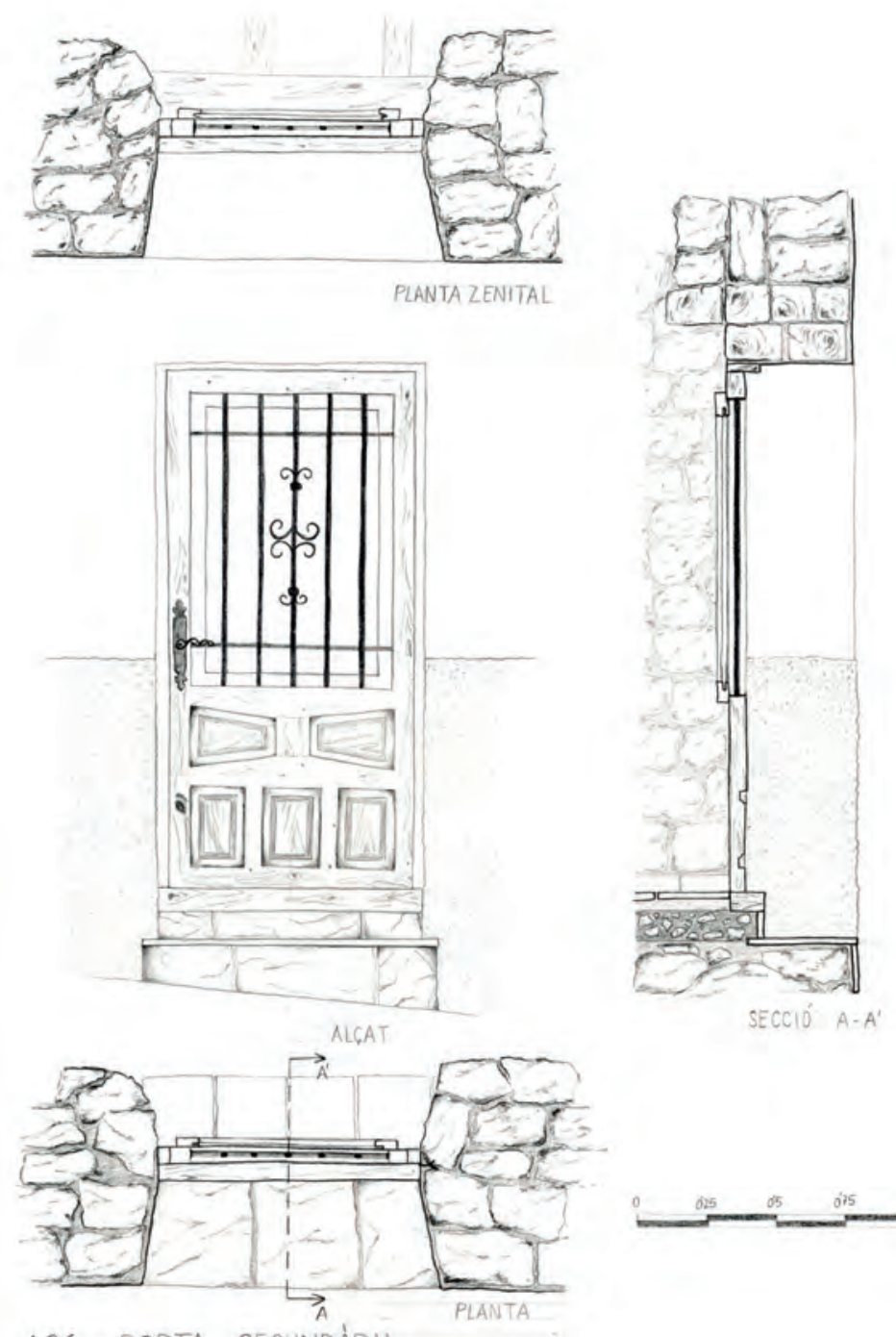

A06, PORTA SECUNDÁRIA

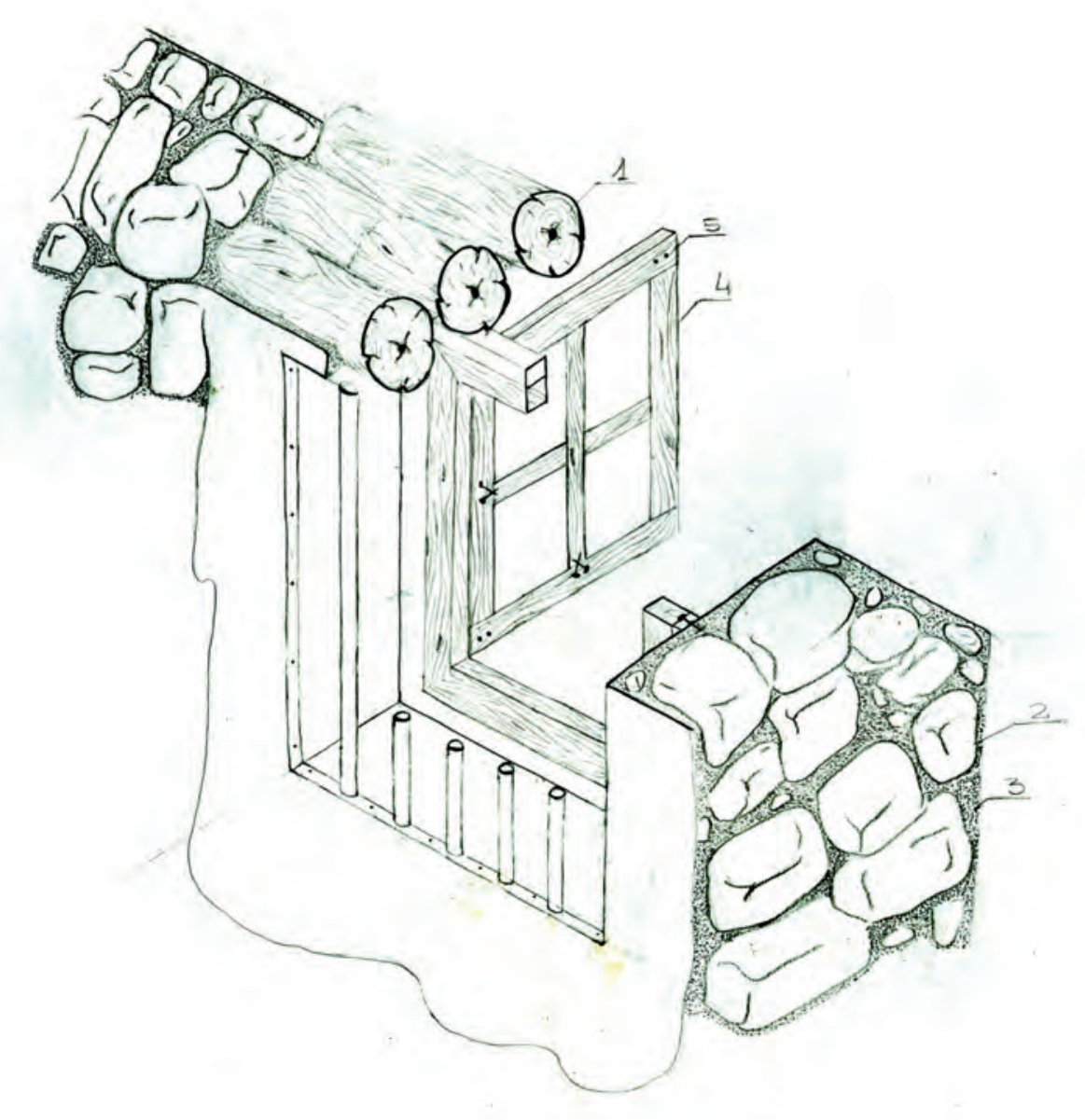




\section{Carreuat-Maçoneria}

La pedra tallada s'ha emprat normalment en edificacions singulars, encara que també la podem trobar en construccions de menor entitat combinada amb altres materials amb l'objecte de reforçar els punts més febles dels murs, com ara les cantonades, els brancals i llindes de les obertures, els sòcols, etc.

En els murs de maçoneria, un factor determinant per a la seua estabilitat és la mida dels carreus de les cantonades i la seua correcta trava amb la resta de les pedres. És habitual la col-locació de pedres tallades en les unions entre murs per a travar-los i afavorir les empentes horitzontals. La pedra emprada sol ser la pròpia del terreny, per la qual cosa sol haver-hi diferències d'apecte entre diferents regions.

En alguns casos es poden observar cantonades romes o aixamfranades en tota l'altura de l'edifici o solament en els primer metres del mur. En aquest cas, la missió sol ser la d'afavorir el pas de vehicles i persones en els carrers estrets.

Als habitatges tradicionals és frequent trobar elements reaprofitats d'altres construccions més antigues, circumstància habitual en els núclis pròxims a edificacions defensives enrunades.

S'anomenen fäbriques mixtes aquelles que han estat fetes amb materials diferents, en les quals les mancances d'uns materials són suplides per uns altres. Podem trobar-hi múltiples combinacions; carreus amb maons, pedra tallada amb tàpia o tova, maons amb pedra de paredar, etc. Depenent de la qualitat de la fäbrica, els paraments poden quedar amb la pedra vista o revestida amb morter (el més habitual) i emblanquinada, amb l'objecte de protegir els materials menys resistents a la pluja i a altres fenòmens propis de la intempèrie.

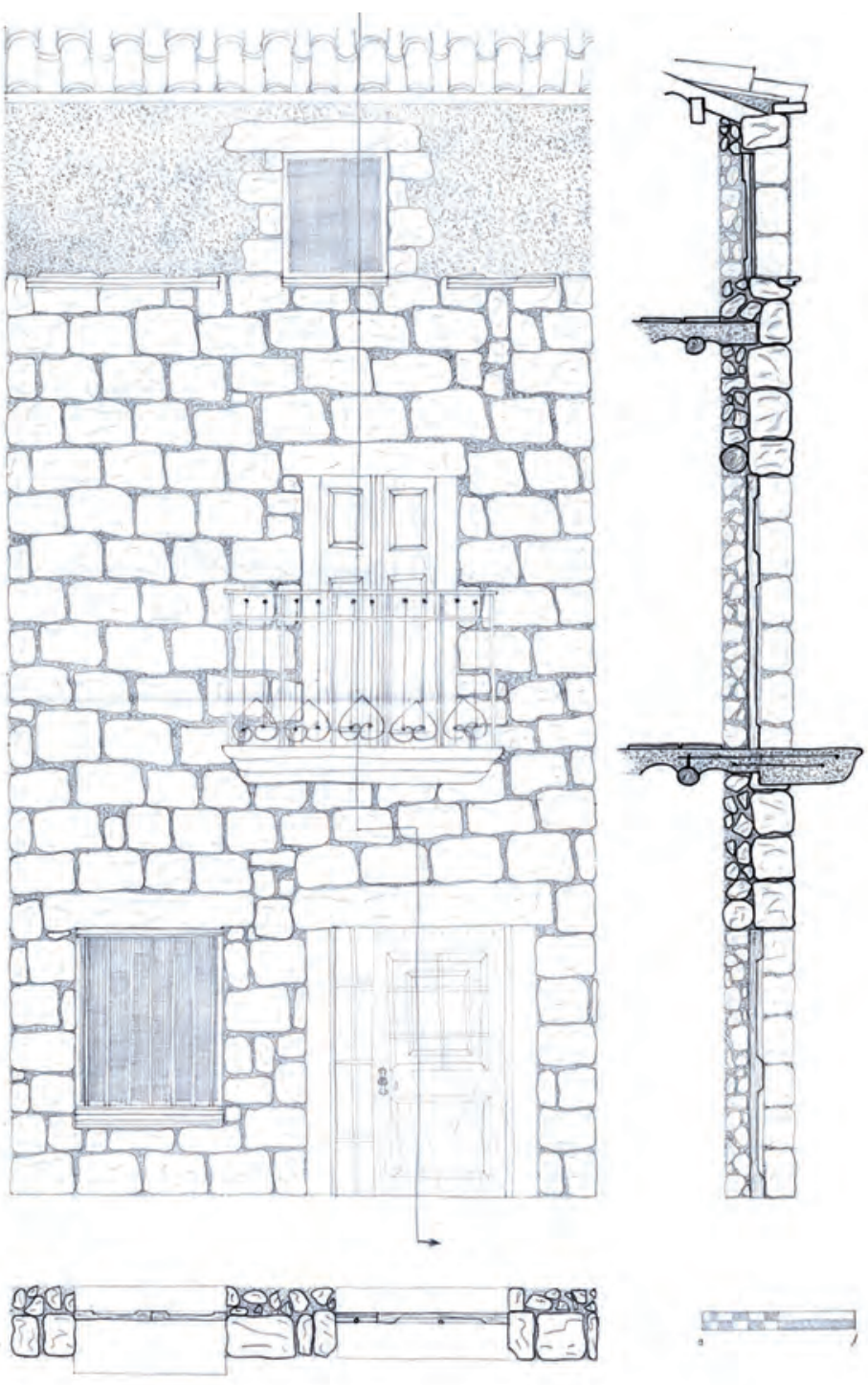



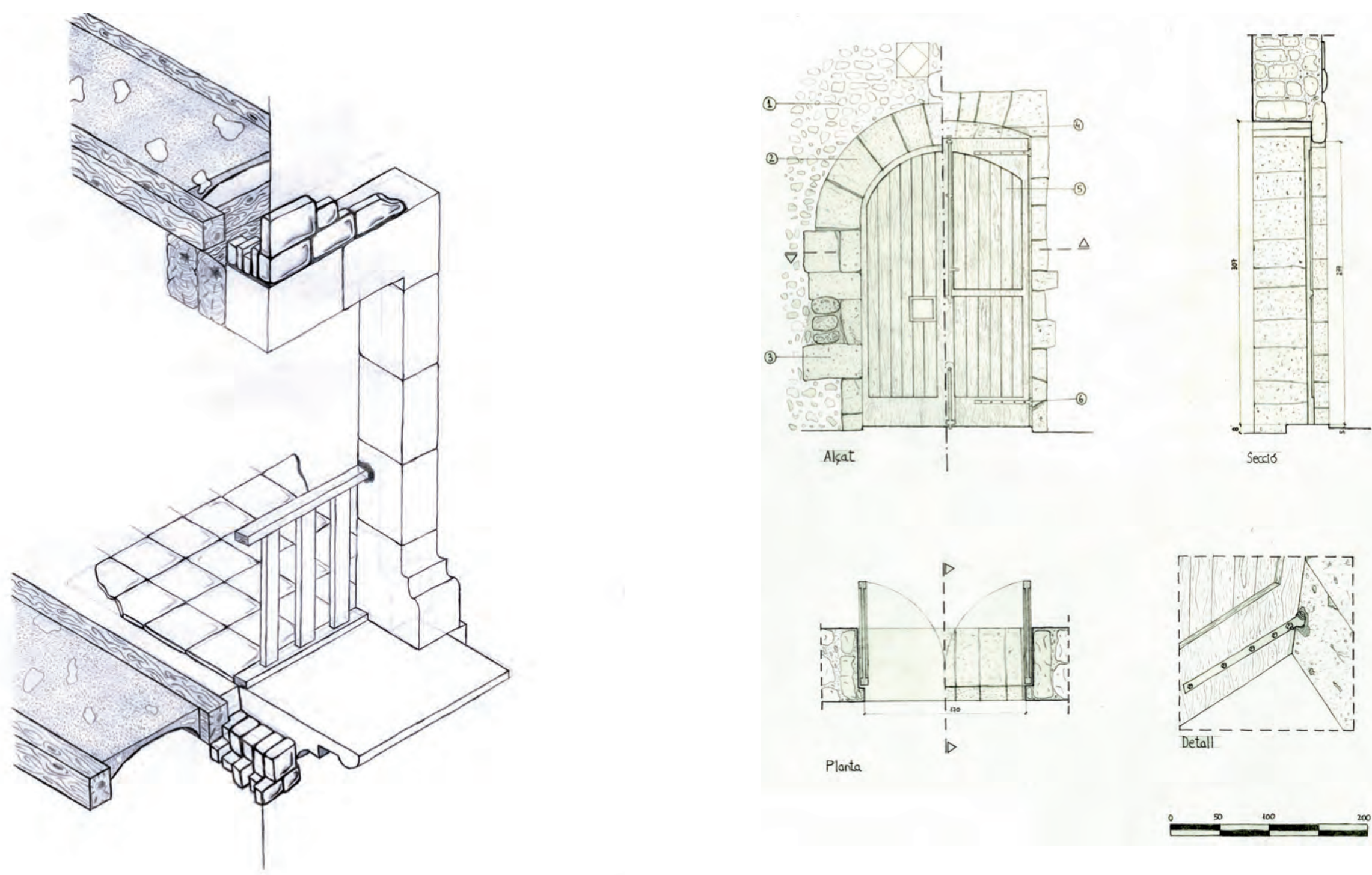


\section{Tova i maó}

La tova és una peça de forma prismàtica feta amb fang argilós, normalment mesclat amb palla, emmotllada i assecada al sol, que s'utilitza per a la construcció de parets i murs. El seu volum permet que siga manipulada per un paleta amb una sola mà.

La col-locació de la tova i del maó correspon a la mateixa família de tècniques constructives; la de l'addició, per mitjà de la qual les peces perden la seua individualitat, ja que es traven amb altres de les seues mateixes característiques per a formar un element homogeni. La unió de les toves es realitza amb fang, mentre que les rajoles s'uneixen amb morter, normalment de calç i recentment de ciment.

La menor resistència de la tova no permet la confecció de pilars de seccions petites, perquè no suporten adequadament les càrregues concentrades.

La reduïda resistència de la tova a la humitat aconsella el seu revestiment amb morter de calç o fang. Els maons, en canvi, es poden utilitzar sense protecció fins i tot en superfícies horitzontals com ara cornises o frisos, formant belles combinacions, però allò més habitual és que es protegisquen amb un revestiment continu i un posterior cobriment de pintura.

Amb els dos materials s'han construït tradicionalment murs portants, normalment amb gruixos d'almenys $25-30 \mathrm{~cm}$.

Amb aquests materials, com que són modulars, es poden alçar murs portants amb un consum de prop de la meitat del material que s'empra en els murs de maçoneria.

És freqüent trobar maons reforçant les parts més febles dels murs de maçoneria, com s'ha explicat en el cas del carreuat. A més, els maons podem trobar-los en la regularització de les filades de pedres conformant verdugades en murs de dimensions considerables.

Cc) Juan A. Garcia Esparza - ISBN: 978-84-695-8048-6
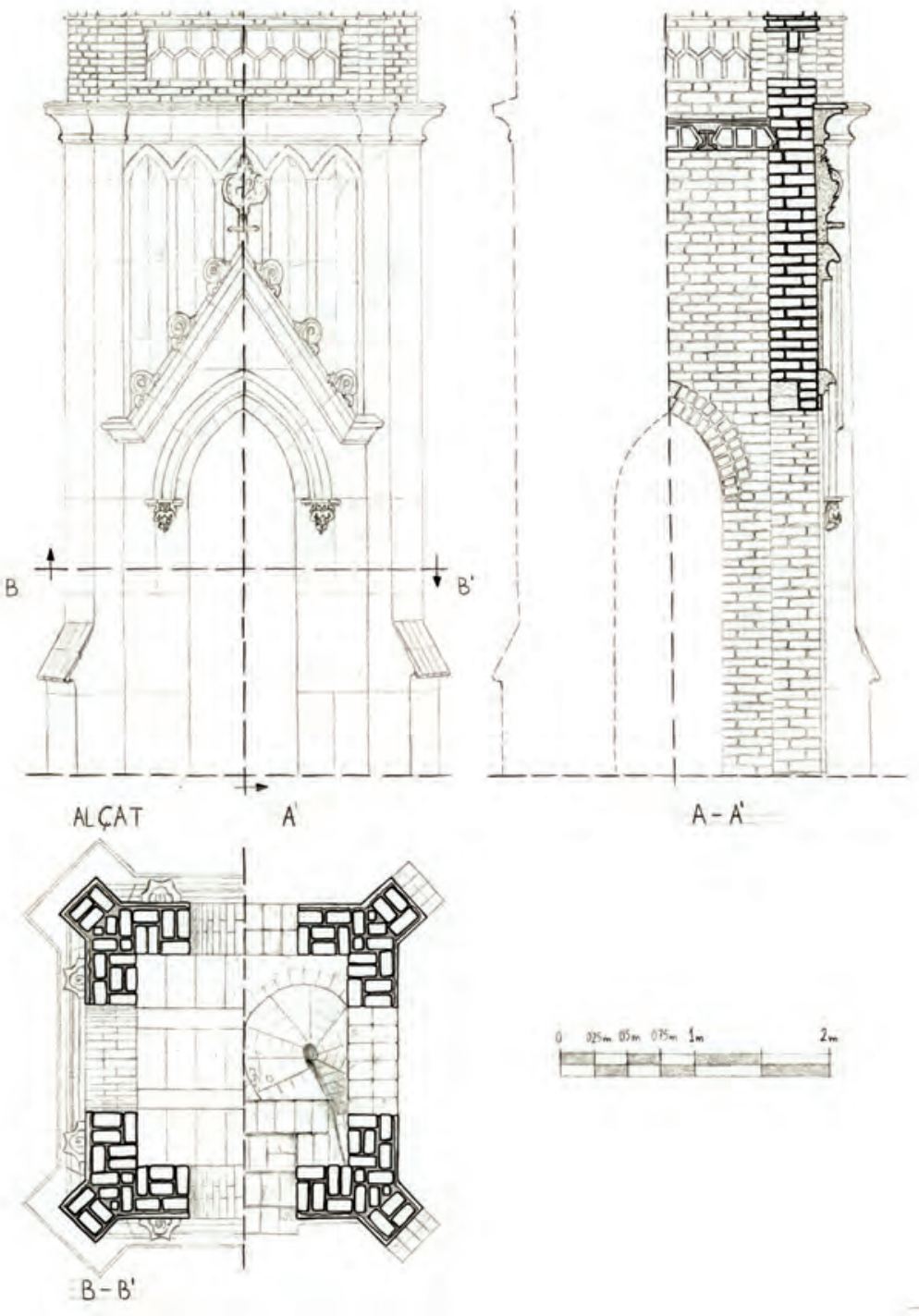


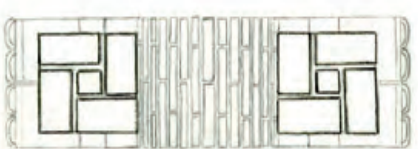

VISTA ZENITAL

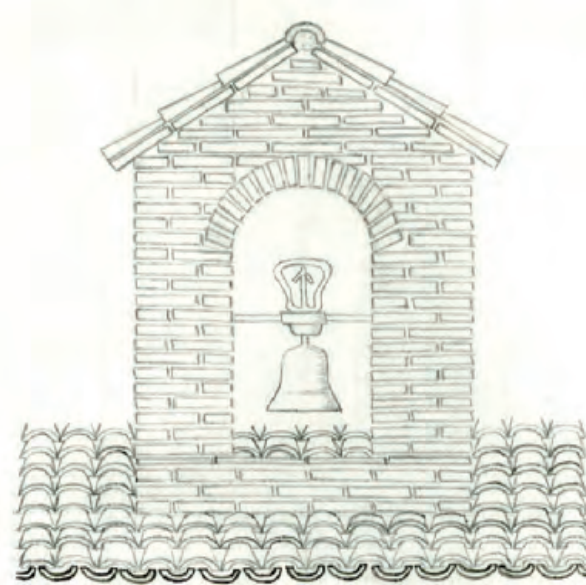

ALCAT

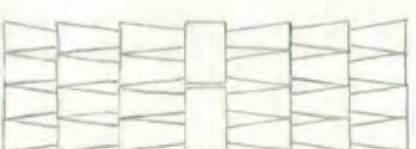

Panta

tecentate

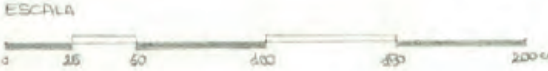

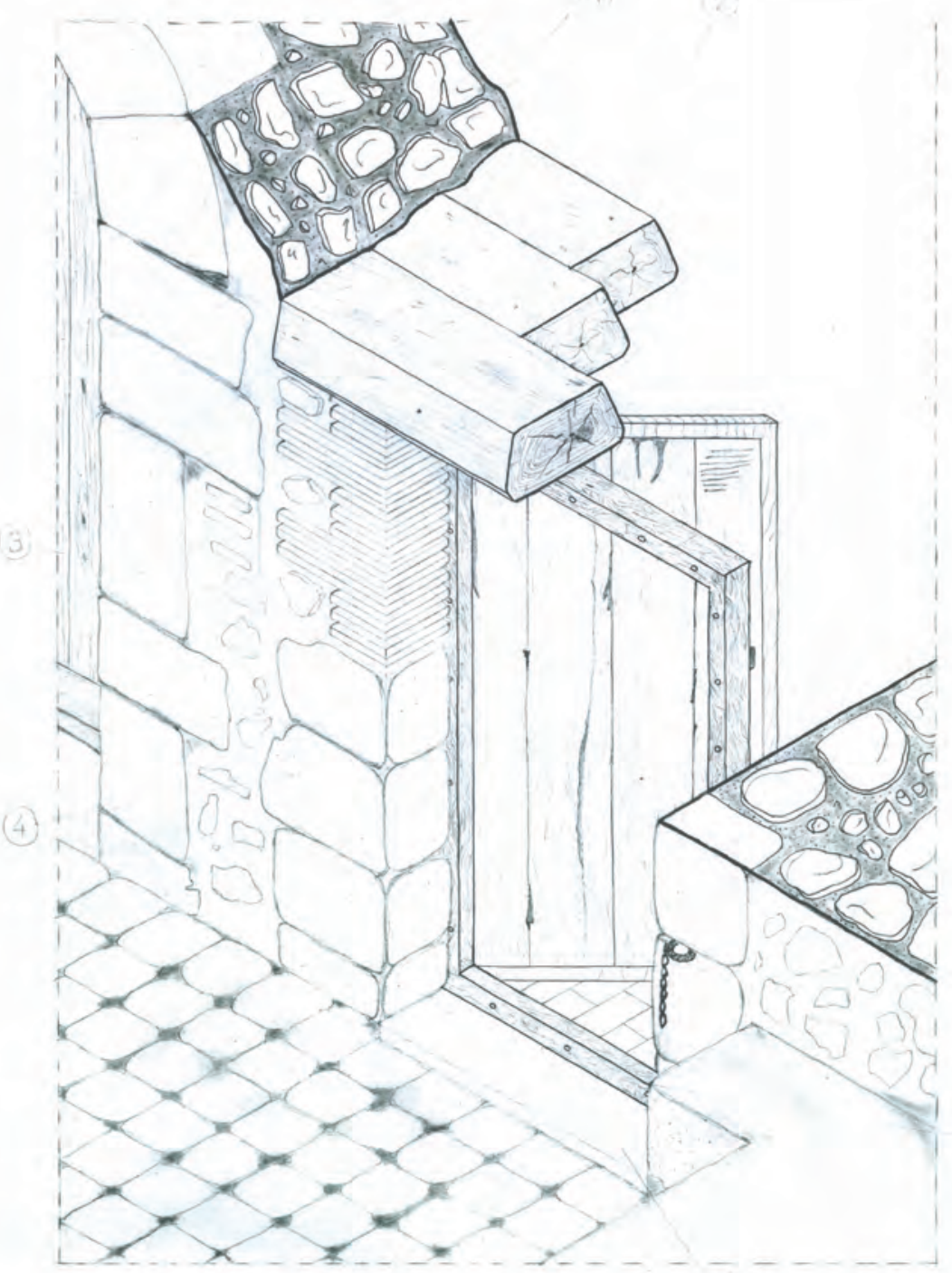

Construcció I, projecte. La mirada i reflexió sobre les tècniques constructives tradicionals - UJI - DOI: http://dx.doi.org/10.6035/Sapientia78 


\section{De tàpia (terra crua)}

Es diu que un mur està executat amb la tècnica de la tàpia quan s'ha realitzat amb l'ajut d'un encofrat o motlle, anomenat tapiera.

La tàpia habitual en la construcció tradicional és aquella en què a l'interior del motlle s'aboca i picona terra humida, a la qual, en ocasions, se li afegeix palla.

L'amplària dels murs de tàpia, mai inferior als $45 \mathrm{~cm}$, compensa la seua reduïda resistència a la compressió, podent-se emprar, per tant, com a murs portants, aconseguint en alguns habitatges fins a quatre plantes. La terra compactada és d'estructura porosa, la qual cosa li confereix al mur un bon comportament acústic $i$ tèrmic.

La terra adequada haurà d'estar composta per argila, llim i sorra i, generalment també grava, en tot cas el que s'ha fet habitualment ha estat emprar la del lloc, encara que no siga la idònia.

Hi ha diferents tipus de tàpia, segons el material principal i la seua posada en obra. La tàpia calicastrada, que és la que porta un revestiment de morter de calç que es col-loca alhora que s'hi aboca i compacta la terra, ha sigut la més utilitzada en la construcció tradicional. Existeixen també les tàpies ordinàries (només de terra), les de formigó de calç o algeps i pedres, i les mixtes, que són les que es formen amb la combinació de diversos materials (maons, pedres, algeps, etc).

D'aparença senzilla, aquesta tècnica ha sigut utilitzada en tot tipus d'edificis. La seua longevitat, igual que la de la tova, està condicionada a la protecció dels següents tres punts fèbles: el basament que l'aïlla de la humitat del terreny, un ràfec prominent que la protegeix de la pluja, i no menys important, l'atenció que cal tenir en la reparació dels possibles desperfectes als paraments dels murs.

Aquesta tècnica, igual que la maçoneria, queda, de vegades, oculta sota revestiments d'algeps o morter de calç, moltes vegades emblanquinats amb calç. 


\section{Obertures}

\section{Finestra}

Les obertures als murs tenen per missió comunicar espais, ventilar, illuminar, etc. Tradicionalment, i fins a la utilització massiva de la construcció porticada, la configuració de les finestres era allargada, dominant l'altura sobre l'amplària.

La solució estructural que cobreix una finestra pot ser per mitjà d'una llinda o un arc, element, el primer, sotmès a l'esforç de flexió que, sense deformar-se o admetent una lleugeríssima deformació, transmet les càrregues als brancals. En molts casos, s'ha emprat l'arc de descàrrega per alleugerir els esforços que actuen sobre la llinda.

Per a la formació d'una 1linda, la col·locació d'una o més peces dependrà de l'amplària del mur. Normalment en les construccions populars en són necessàries, almenys, dues peces.

La llinda fa les funcions d'una biga que rep directament una càrrega uniformement repartida que transmet als brancals. La concentració d'esforços que reben aquests elements fa necessari que la seua execució siga acurada i que es faça amb elements de suficient resistència i de mides superiors a la resta de peces que formen el mur. Aquesta exigència serà una constant en l'edificació per a aquells elements que suporten càrreges concentrades, com per exemple els pilars. Així, en nombrosos casos s'arriba a emprar pedra tallada en paraments de maçoneria.

La utilització de l'arc per a cobrir les obertures ha sigut una constant al llarg de la història de la construcció, sent el traçat de la seua directriu definitori dels distins estils arquitectònics. Els materials emprats han sigut els petris: pedra, maó i tova.

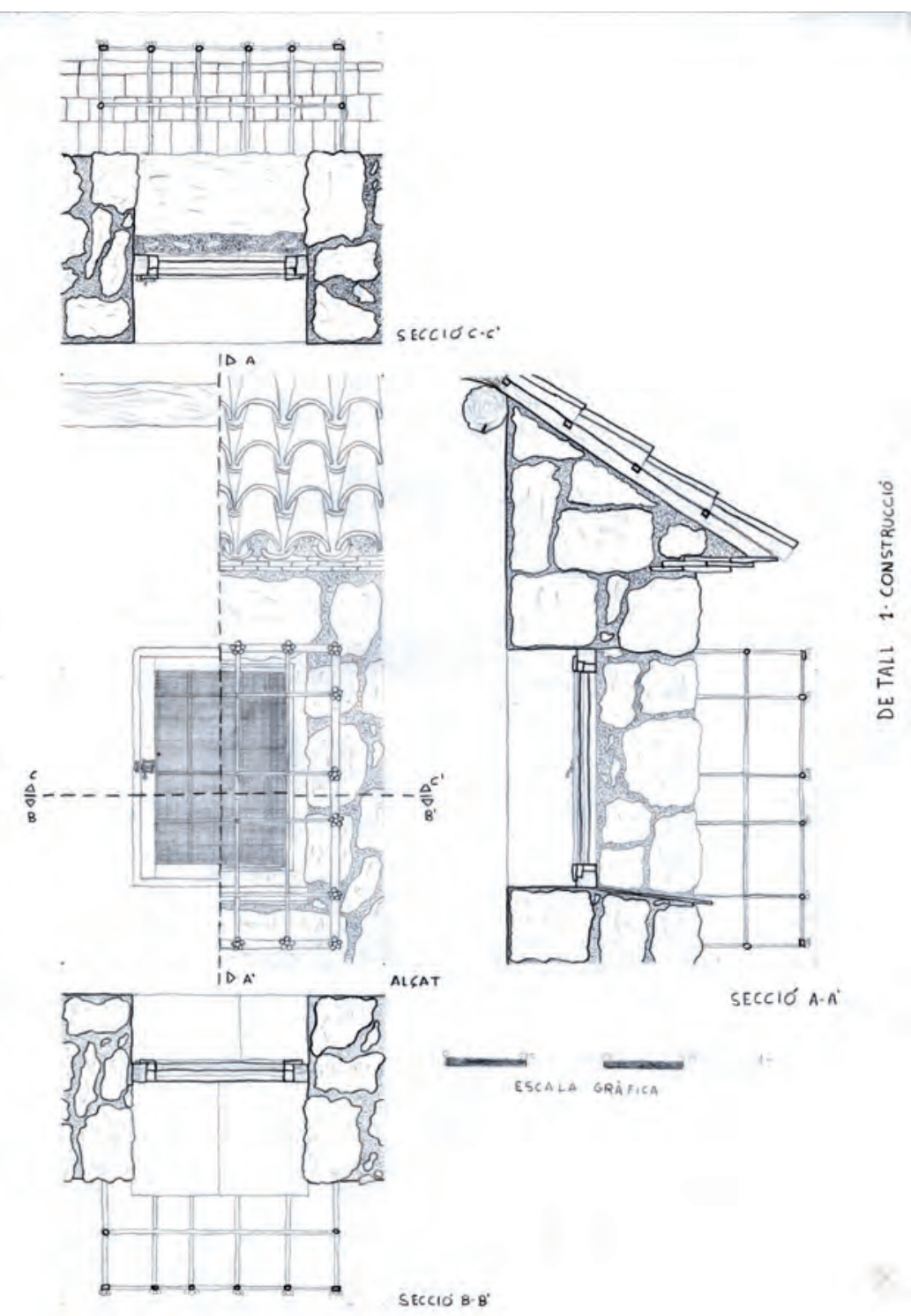



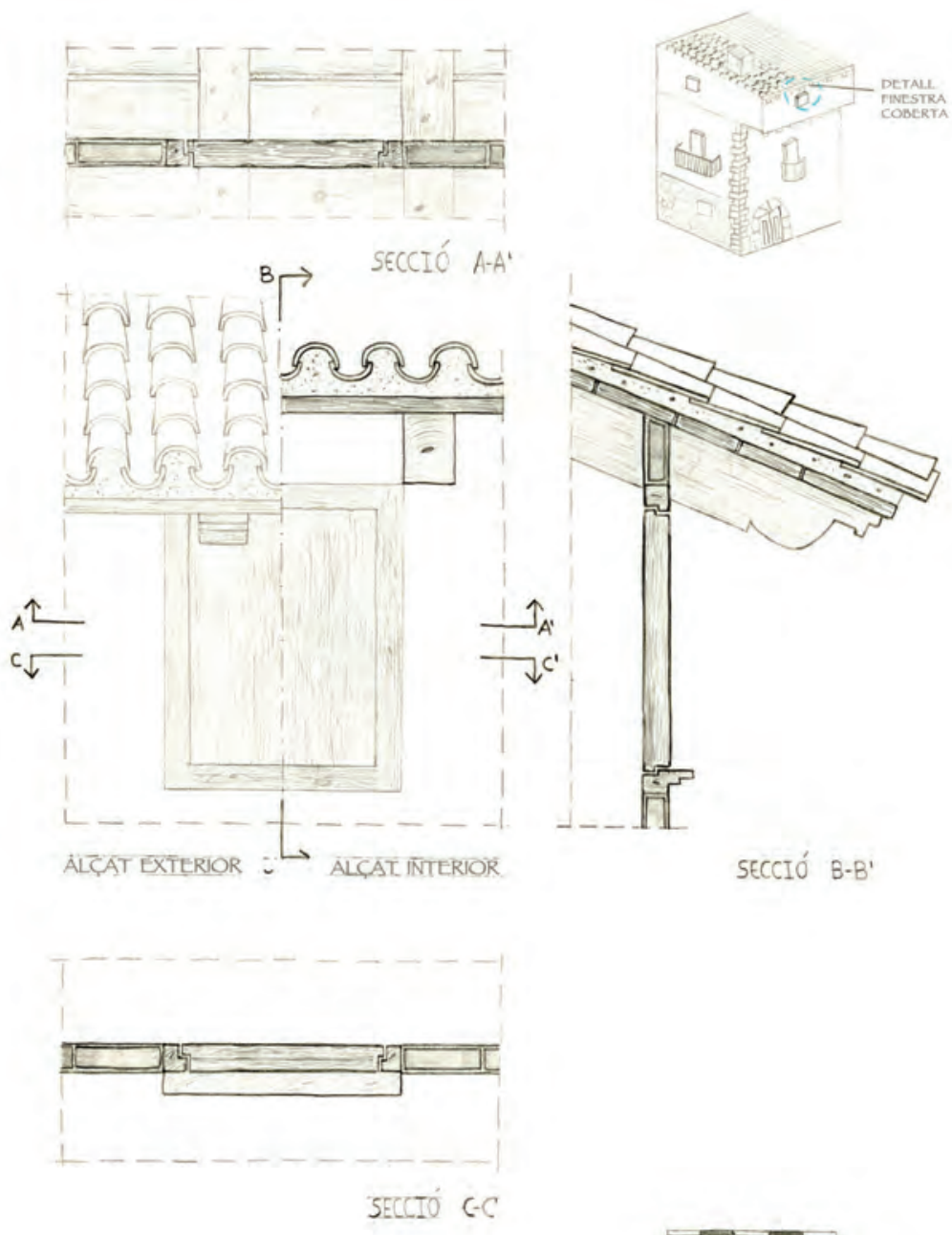

SECCTO C-C

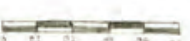

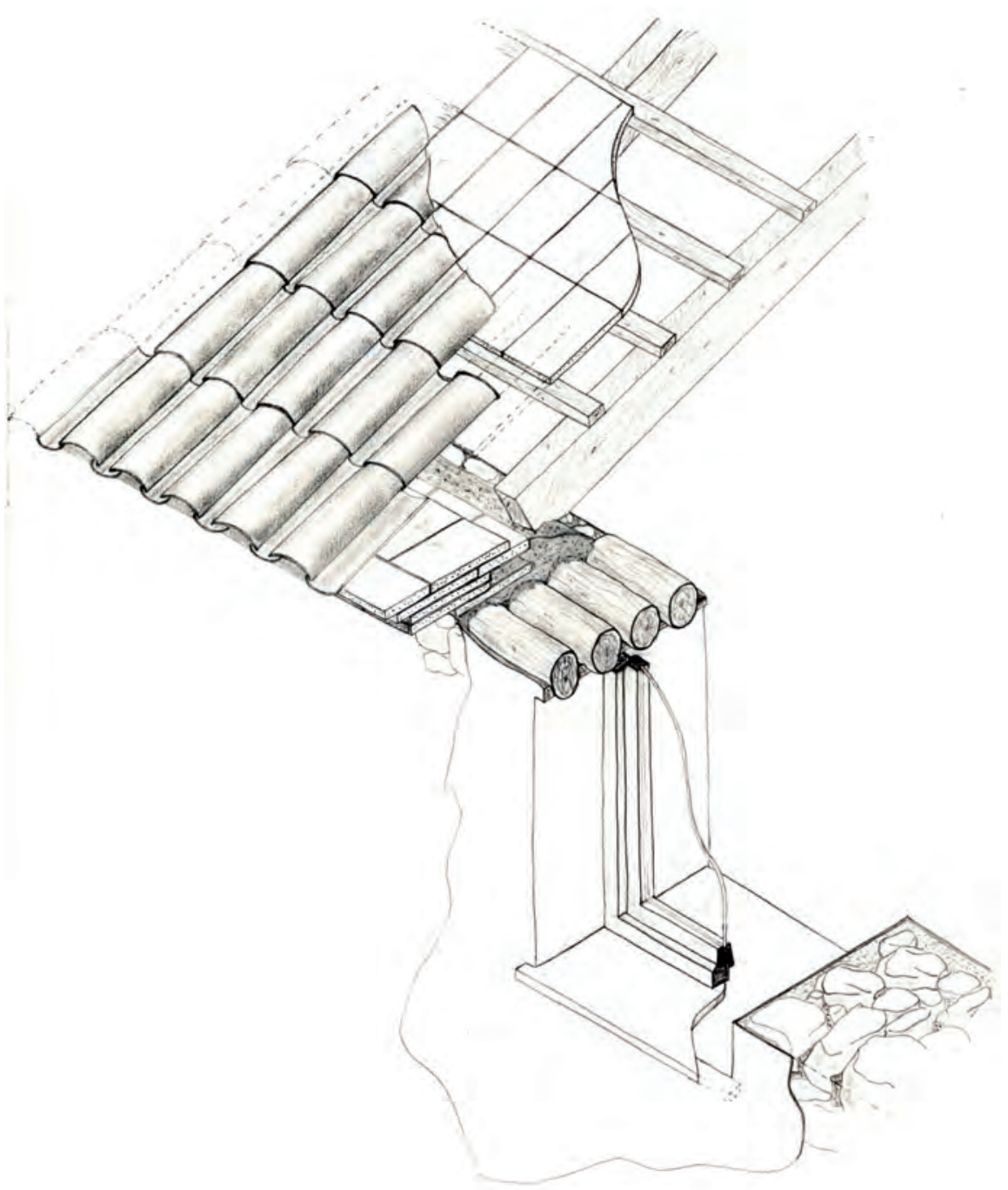

Construcció I, projecte. La mirada i reflexió sobre les tècniques constructives tradicionals - UJ - DOI: http://dx.doi.org/10.6035/Sapientia78 


\section{Porta}

En els murs de carreuat les obertures es cobreixen normalment amb una peça de pedra que treballa a flexió, o amb arcs. Els de directriu més freqüent són el mig punt, el rebaixat o l'arc de llinda.

En les fàbriques de maó sol resoldre's l'element superior d'una obertura, si és en arc, amb rajola, però també amb carreus o altres peces prefabricades. Aquestes solucions permeten obrir obertures de major llum que en les obres fetes amb pedra de paredar. bàsicament per la irregularitat en la seua forma.

Són també els casos de la tova, de la tàpia i de la pedra en sec. En les tècniques de terra, per a conformar la porta, sovint se'n fa ús d'un marc complet de fusta que col-labora en la rigidesa del conjunt de llinda i brancals, amb la finalitat de compensar els riscos de deteriorament del material. En les fàbriques fetes amb aquests tres materials l'àmplaria de les obertures no sol ser superior a un metre, sent, normalment la porta d'entrada a l'habitatge la de major amplària.

Finalment, cal dir que totes les obertures, no sols serveixen per a il·luminar l'interior sinó també, són un lloc d'observació, un mirador social, l'última zona privada que es projecta sobre l'espai públic.

Les obertures per a portes i finestres rebran els elements de fusteria que regularan la llum, el pas de les persones i de l'aire i protegiran els usuaris de l'habitatge de l'exterior. També les obertures poden entendre's com un element purament estructural de grans dimensions, en forma d'arc o allindanat, que substitueix porcions significatives de parament. Aquestes normalment posseeixen un nom específic: portal o portalada, porxo, llotja, etc

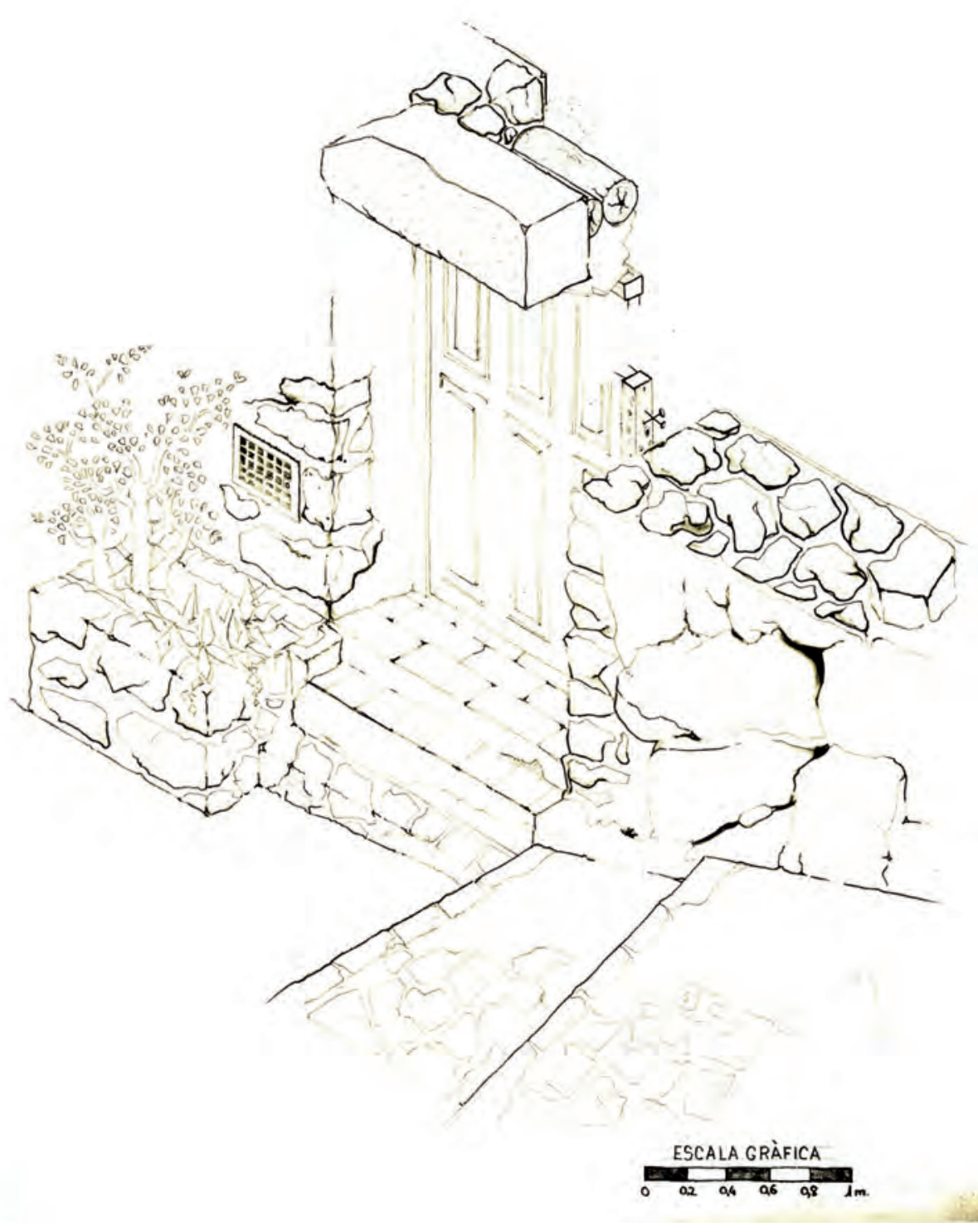

Construcció I, projecte. La mirada i reflexió sobre les tècniques constructives tradicionals - UJI - DOI: http://dx.doi.org/10.6035/Sapientia78 


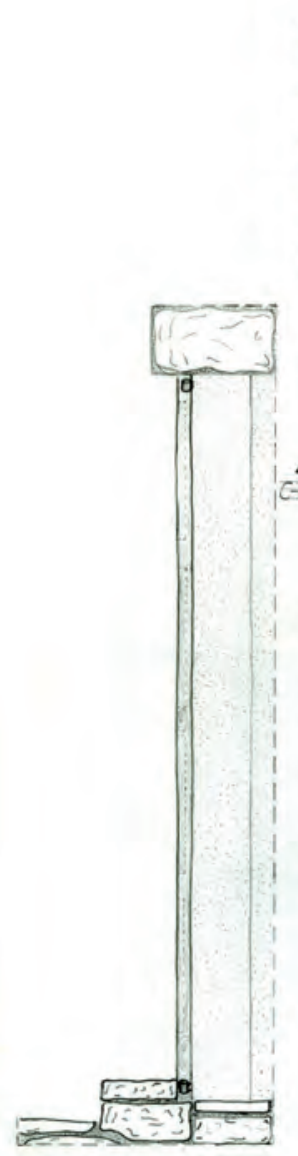

Seccio. Vertical $B-B^{\prime}$

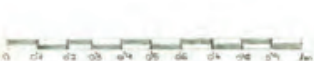

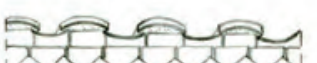
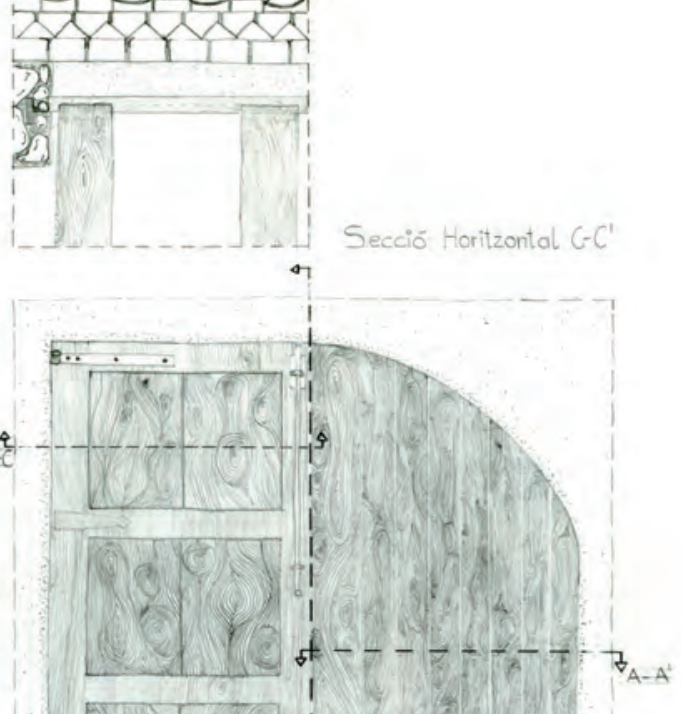

मrinat i
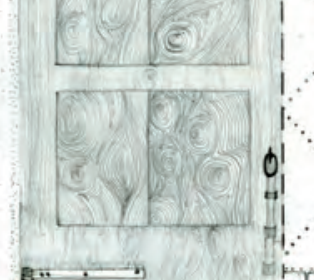

年

Alcat Postenior $\quad$ SB-B' Alçat

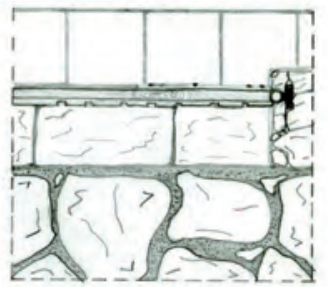

Secció Horitzontal 4.A
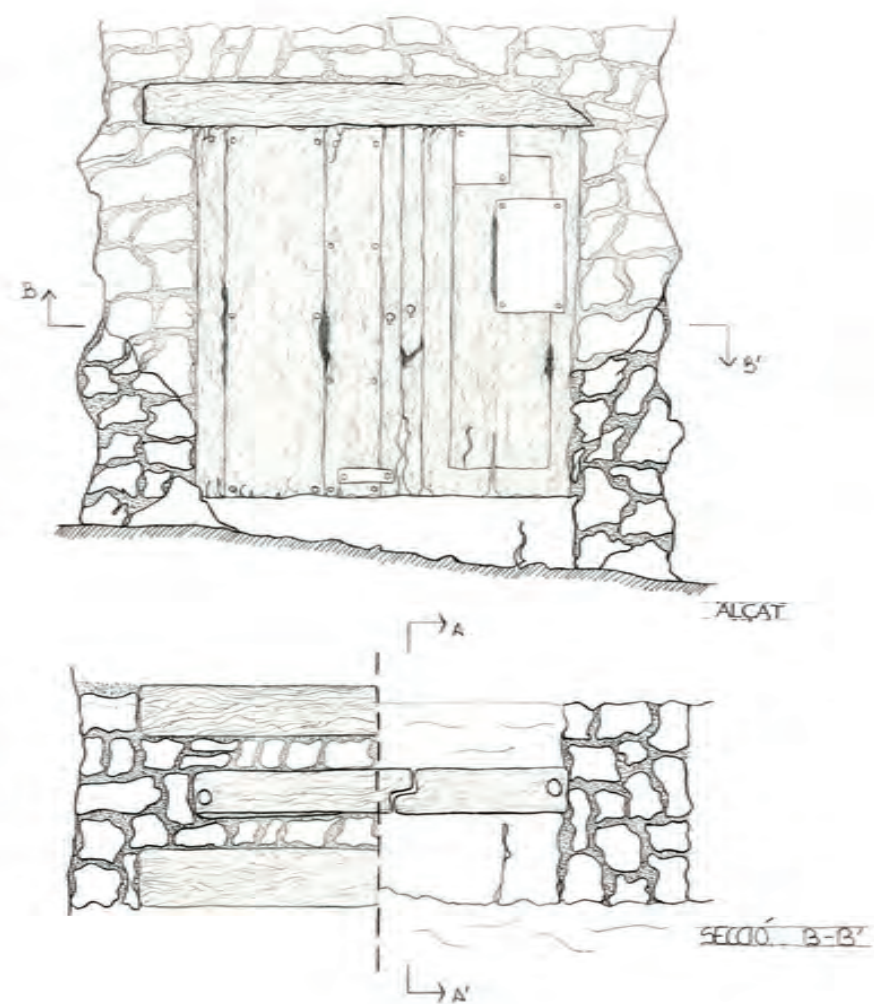

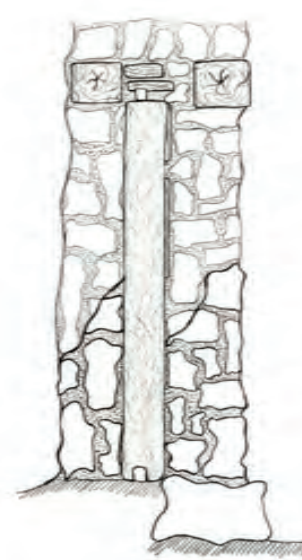

Fुप्रि $A-A^{\prime}$

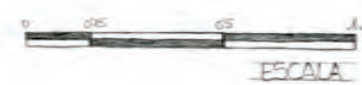




\section{Balcó}

El balcó és un element que ha evolucionat a partir de la petita finestra quadrangular. La seua forma més primitiva i tradicional és el balcó rasant, aquell en què un perfil o barana s'alinea al parament exterior del mur, $\mathrm{i}$ hi queda fixat amb argamassa i, moltes vegades, claus per a millorar-ne la subjecció. L'evolució com a balcó de fusta, es presenta com una estructura ixent, un entaulat de fusta, sobre permòdols perpendiculars al parament del mur. Sempre proveït d'una balustrada i de vegades cobert per la prolongació de la coberta de la casa, o per un teuladell propi compost de cabirons empotrats al mur.

On la disposició del material ho permetia, la pedra reemplaçava la fusta en tots els elements portants del balcó. Aquest va evolucionar cap a una estructura metàl-lica que unificava la seua base amb la balustrada, oferint més lleugeresa i inèrcia al conjunt enfront de la bolcada. Tant la base com el passamà de la barana s'introduïen en el mur augmentant l'estabilitat del conjunt. Sobre l'estructura de la base es col-locaven taulells ceràmics o llosetes pètries sobre les quals s'abocava un morter o argamassa per dotar de monolitisme al conjunt i servir de paviment.

Una solució posterior és la que ja la barana deixa de tenir la missió de sostenir la base del balcó, aquesta missió es deixa a una llosa de formigó armat amb perfils de ferro incrustats en el mur.

Una altra tipologia d'aquest element, però menys comuna, són les balconades i les galeries.

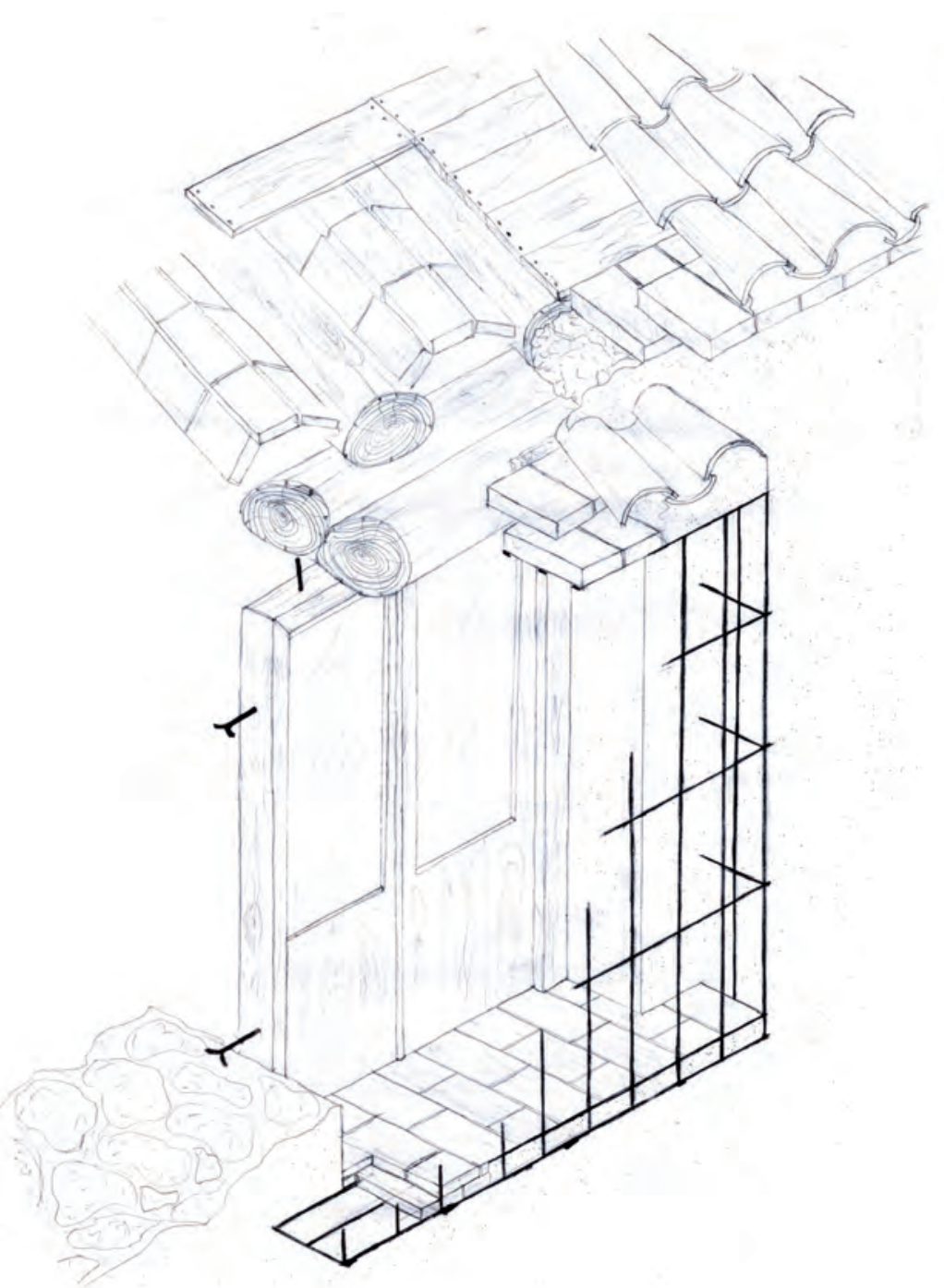




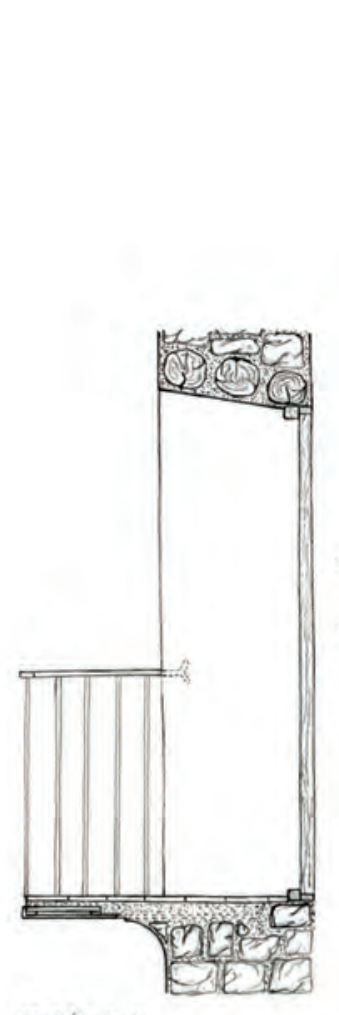

sterio A-A
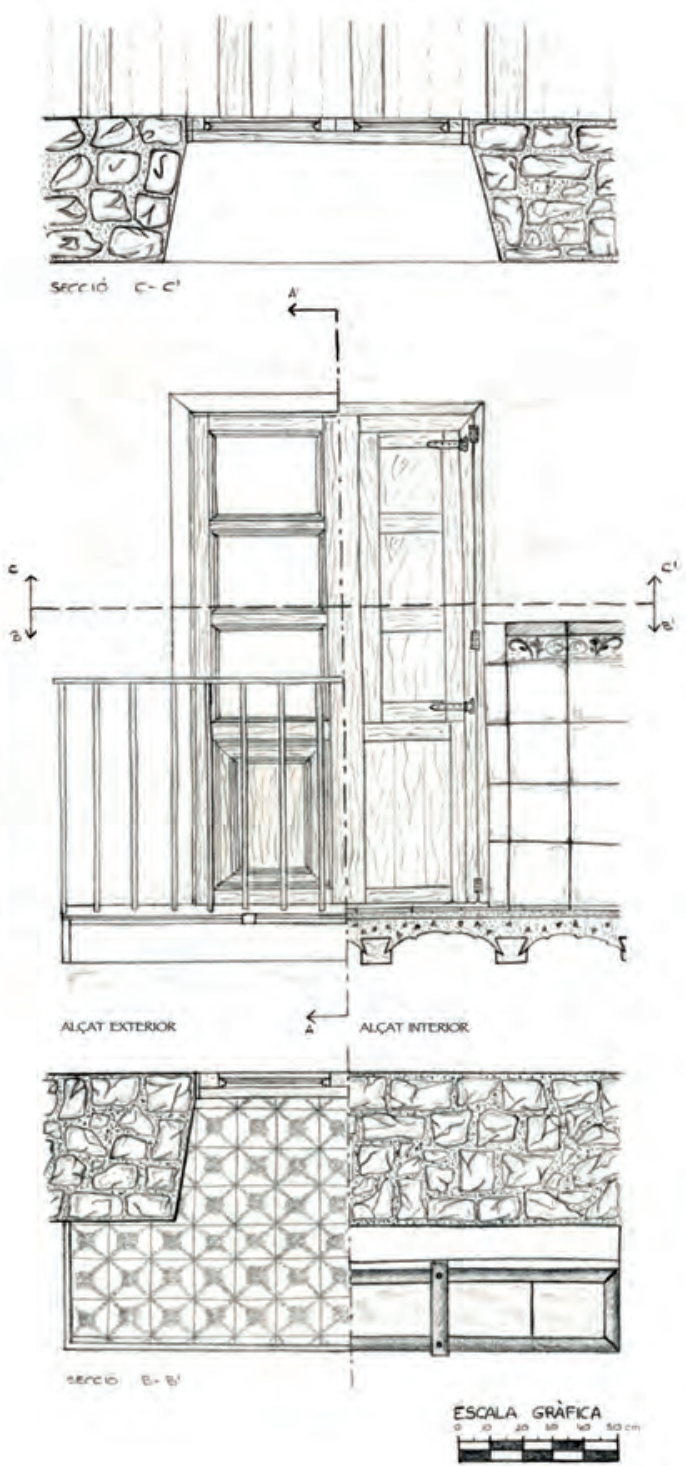

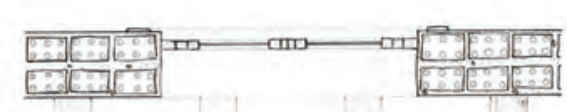

Secció $B \cdot B^{\prime}$
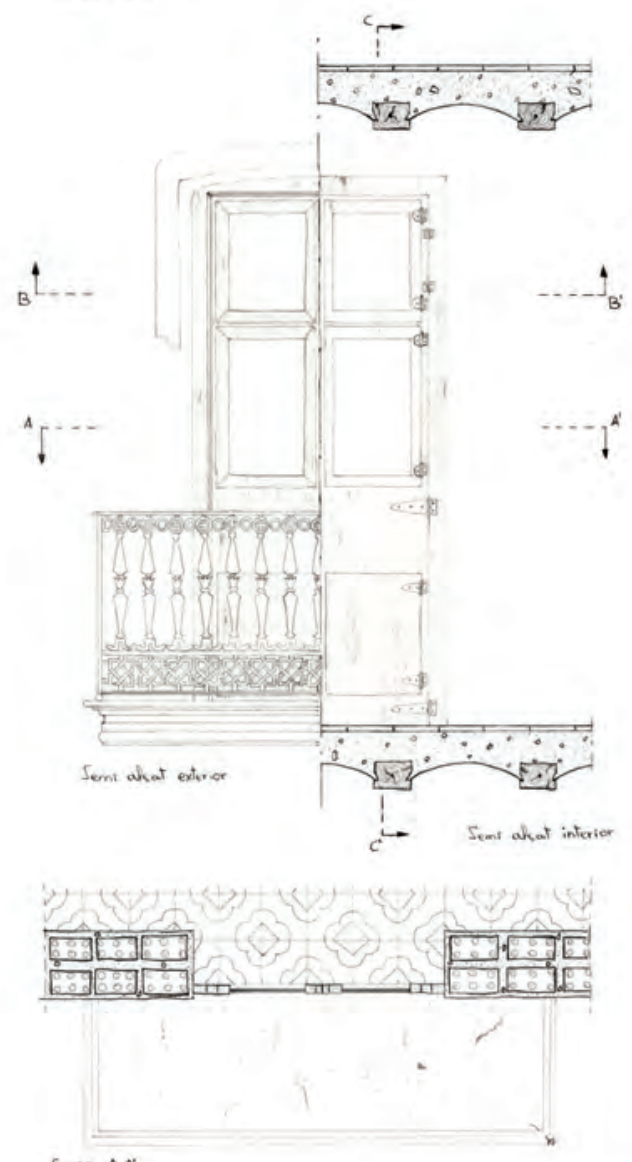


\section{Arcs i voltes de carreu}

\section{Arc}

La idea d'assimilar el funcionament dels arcs al de cables invertits està en el mateix origen de la teoria dels arcs. Robert Hooke diria: «De la mateixa manera que penja el fil flexible, així, però invertit, se sostindrà l'arc rígid», de la mateixa manera que una cadena penjant $o$ catenària.

Per a executar un arc conformat per dovelles de pedra, aquestes es colloquen sobre una cintra, després d'assentar l'última pedra -la clau- es procedeix a descintrar. Les pedres tendeixen a caure cap avall impulsades pel seu propi pes -la llei de la gravetat-, no obstant això, l'arc se sosté i cada una de les dovelles roman en equilibri amb les empentes -resultants de tensions de compressió- produïdes per les dovelles adjacents. Aquestes empentes es transmeten cap als suports; la trajectòria es denomina línia d'empentes. La línia d'empentes és el lloc geomètric de pas de la resultant per un sistema de plans de tall i es troba en tot tipus d'arcs; aquesta ha de quedar sempre compresa dins de la fäbrica, en cada una de les juntes.

Les empentes han de ser inclinades i la seua component horitzontal (empenta de l'arc) constant en tot l'arc.

Si els estreps cedeixen en assentar-se l'arc després del descintrat, aquest cedirà $\mathrm{i}$ es clevillarà per a adaptar-se $\mathrm{al}$ moviment. Però poden produir-se esquerdaments o articulacions més severes quan la línia d'empentes toca la vora de la fàbrica. Heyman va suggerir com a forma de mesurar la seguretat d'un arc comparar la seua grossària amb la de l'arc límit corresponent, donant-se un coeficient de seguretat geomètric.

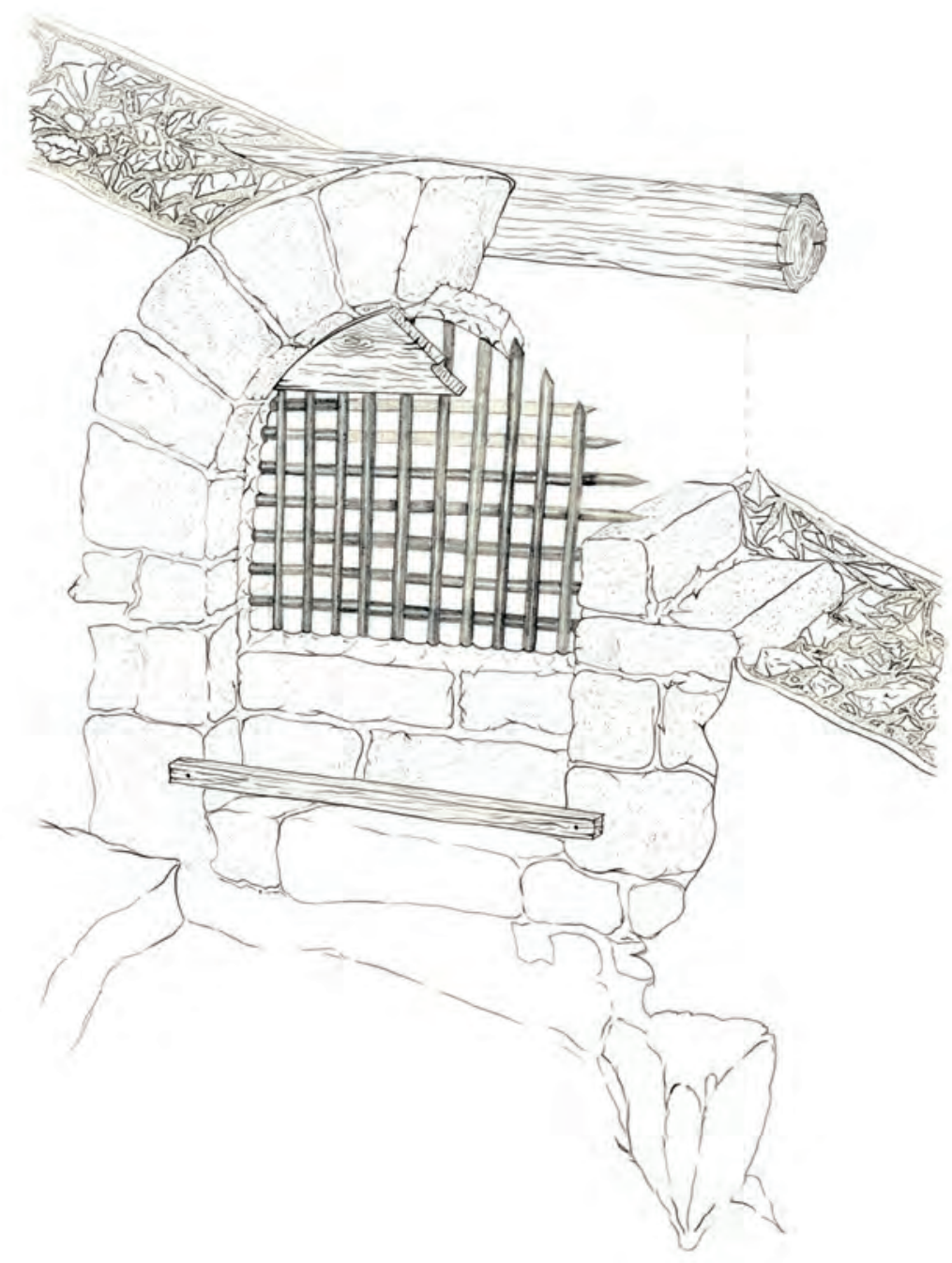



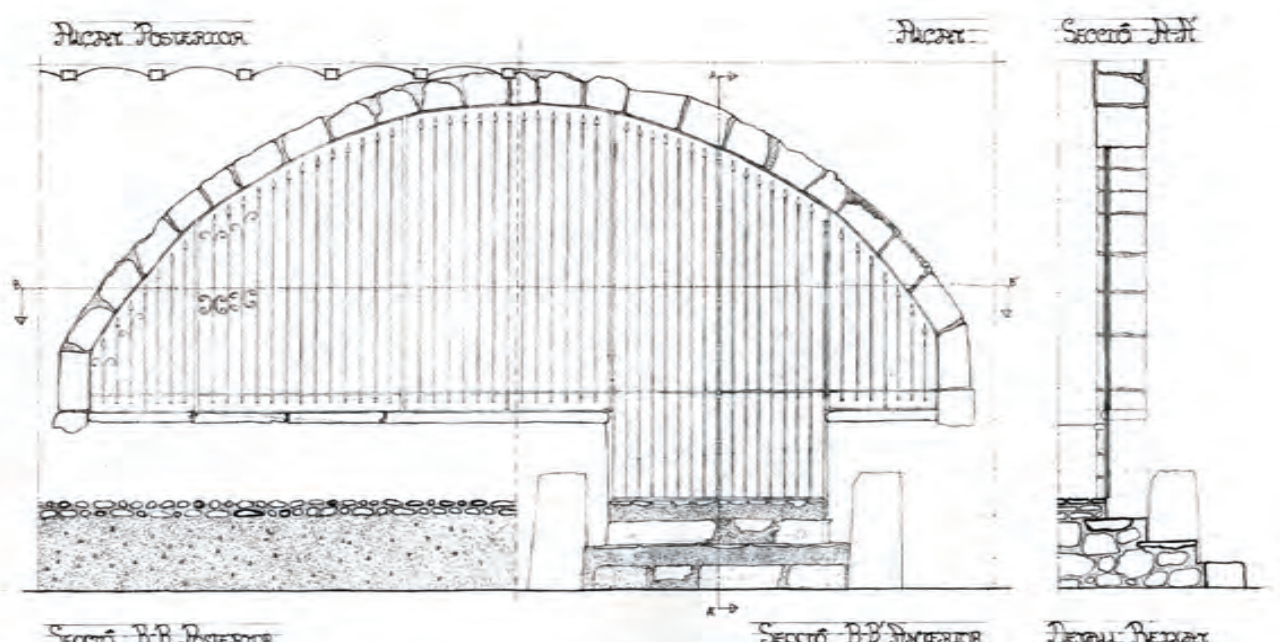

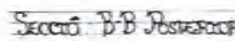

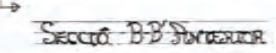

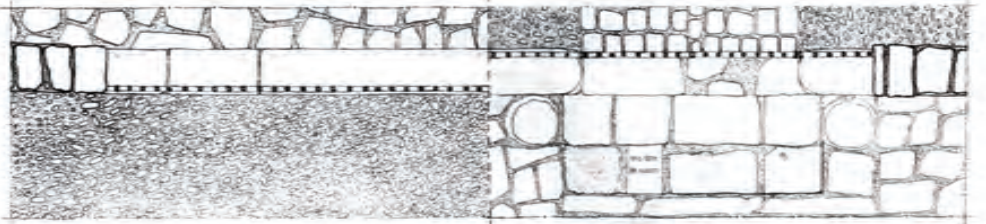
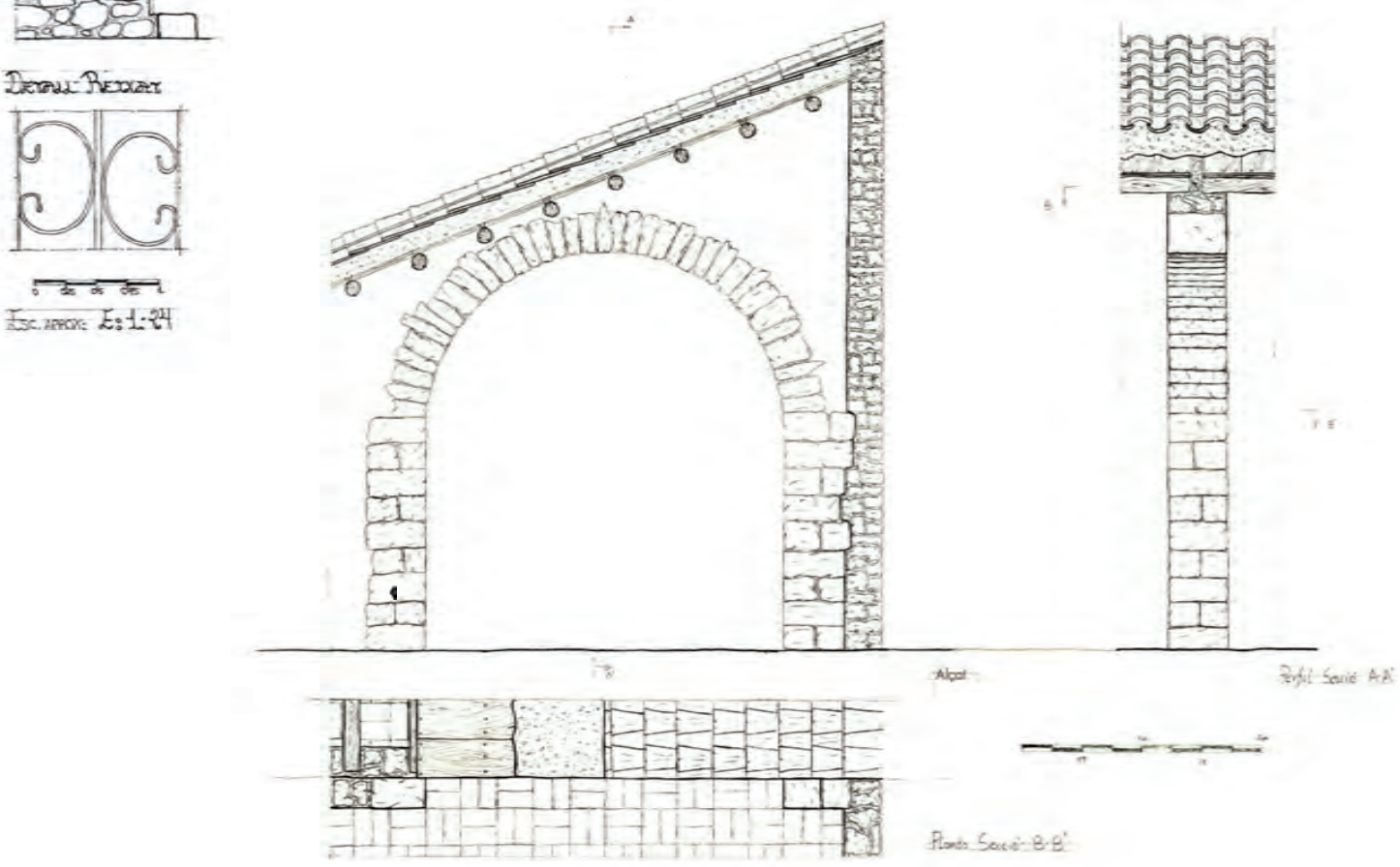


\section{Volta}

Les voltes són elements constructius concebuts per a salvar l'espai entre dos o més suports i per a cobrir una superfície. Poden, per si mateixa, constituir el suport d'una superfície d'ús, forjat, coberta, terrassa, escala, o ser també, el tancament mateix d'una construcció a falta únicament del material de cobertura.

Aquesta solució estructural va substituir la construcció de la volta falsa que només permetia cobrir espais de reduïdes dimensions a causa de la projecció horitzontal en volada dels petris, limitada per la basculació de la peça que sobresurt. Des de la part superior de la volta es trasmeten les càrregues a les peces contigües i així successivament fins a trobar l'estabilitat en un suport vertical en què arrepleguem les tensions. Les voltes pertanyen a la denominada construcció homogènia, ja que són la continuació dels murs, en la majoria dels casos, molt grossos en la part anomenada ronyons, per la qual cosa, si el conjunt de l'obra perd l'equilibri de forces amb què es va projectar, tendeix a caure i enfonsar-se a causa del seu considerable pes. Aquest sistema constructiu és adequat per a obres lineals i executades per repetició, per a cobrir grans llums.

La tipologia més freqüent és la volta de canó, generalment de mig punt, ja que el semicercle transmet les càrregues verticals de forma més homogènia fins als suports; normalment són paraments continus i amb poques obertures. La intersecció perpendicular de dues voltes de canó - volta de creueriafunciona de forma diferent. Cada porció de volta transmet les càrregues de forma concentrada a uns suports aïllats i no sobre el mur. Així es poden aconseguir obertures en els quatre plans verticals que tanquen els costats de l'espai voltat per mitjà de la presència de quatre pilars ben dimensionats en els angles.
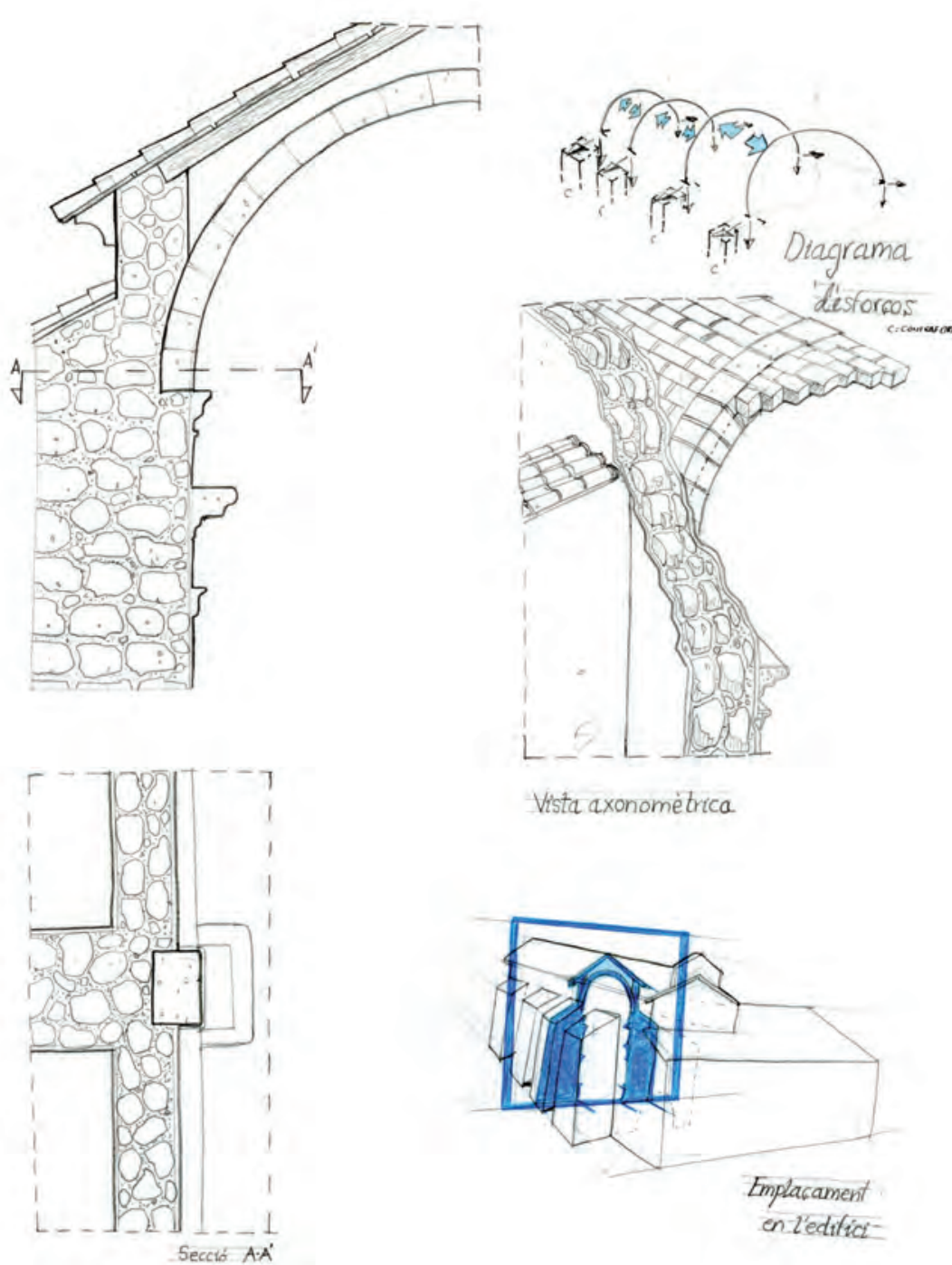

Vista axonométrica

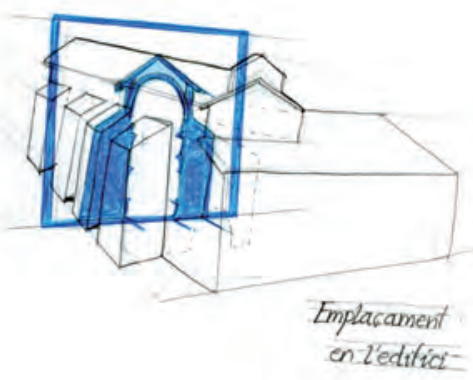




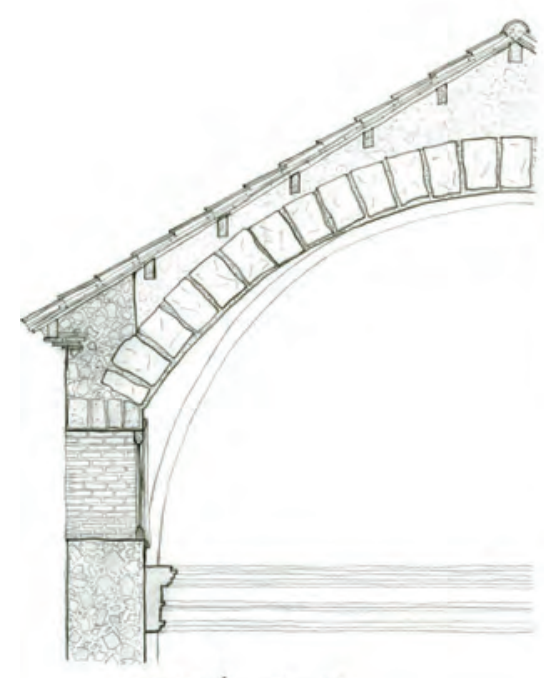

SECCIÓ A A

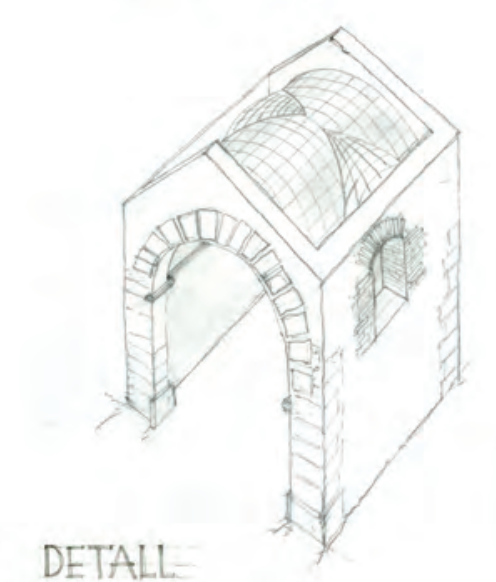

DETALL-

LLUNETA

Exमry

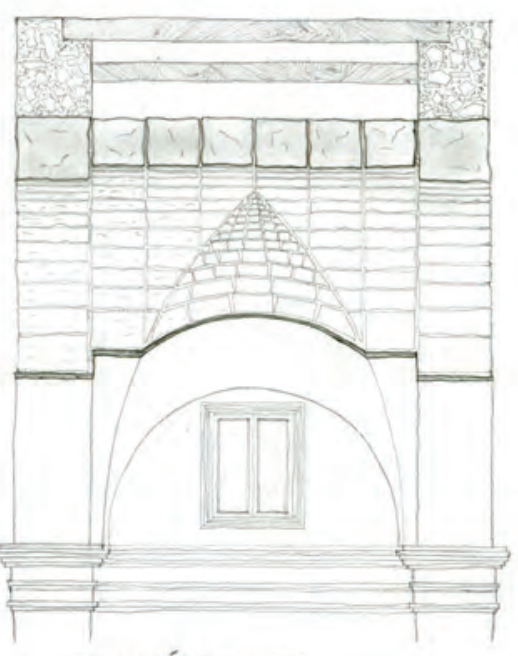

SECGIÓ $=B-B^{\prime}$

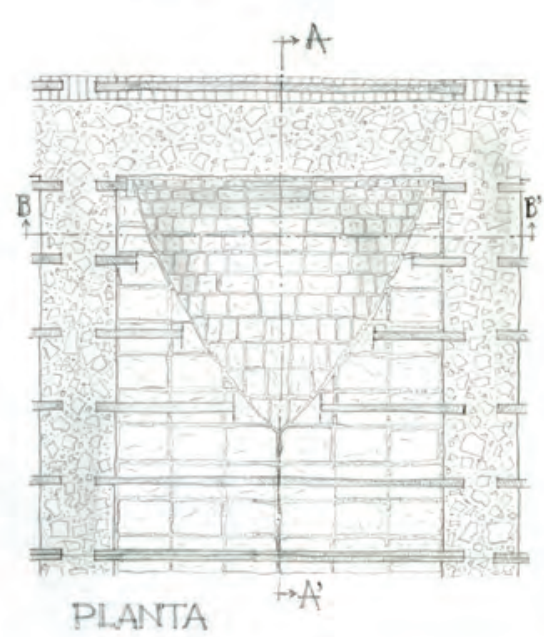

PLANTA

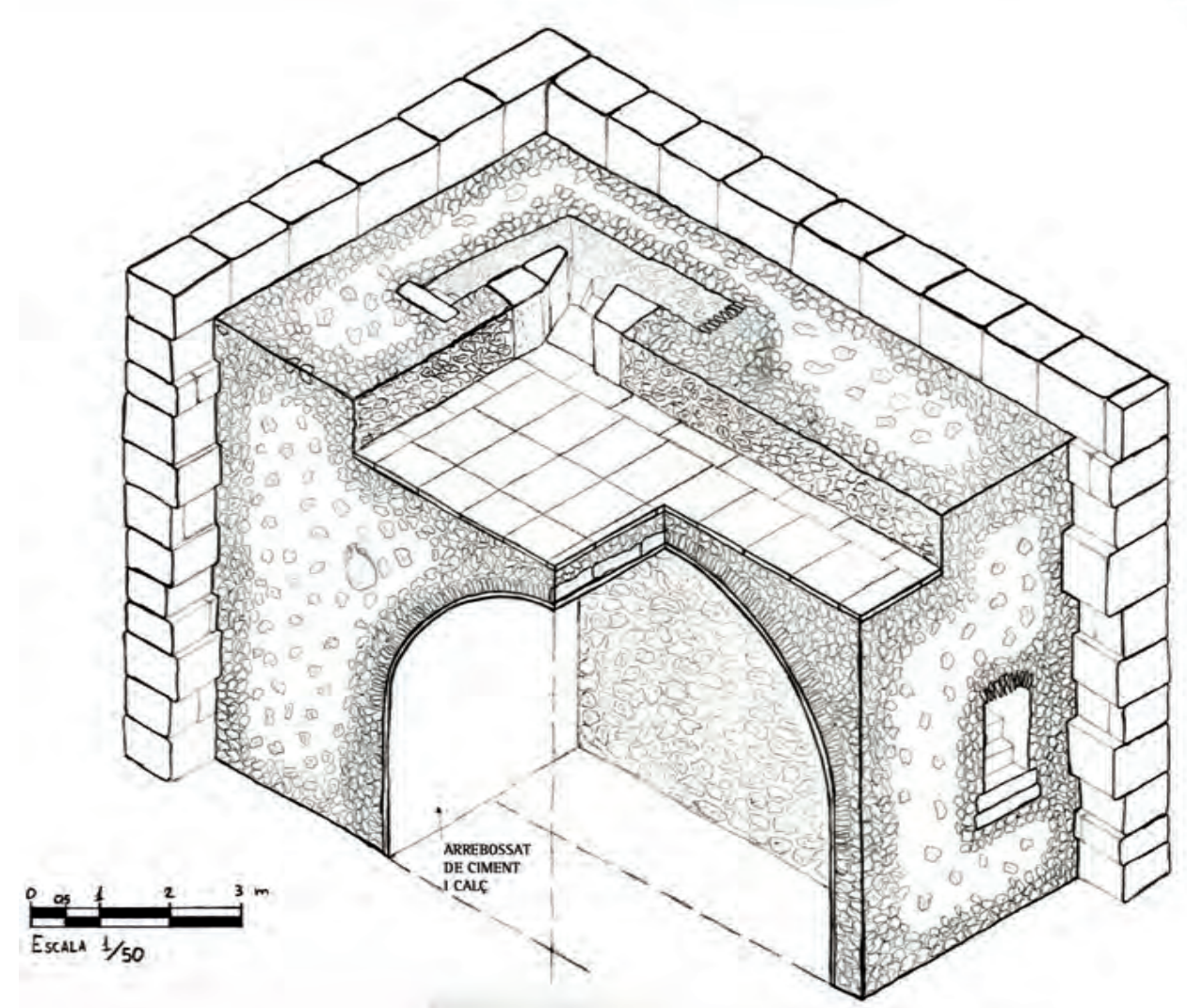

(c) Juan A. García Esparza - ISBN: 978-84-695-8048-6 


\section{Arcs i voltes de maó}

\section{Empentes i resistències}

Els arcs i en general les estructures voltades, a diferència de les allindanades, transmeten les càrregues en direcció inclinada en què la component horitzontal serà major si la seua generatriu és més apuntada i menor si aquesta es rebaixada. Per a contrarestar aquesta component i assegurar l'estabilitat del conjunt s'ha recorregut a estrebar els murs, primerament recurrent a murs d'una gran amplària i després per mitjà de contraforts.

Per a l'estabilitat del conjunt, els estreps, o estructura vertical que suporta l'arc, la volta o cúpula, han de resistir la càrrega que aguanten a pesar de ser considerat com un problema secundari. Per a evitar la fallada per lliscament en l'encontre entre l'estructura voltada i els estreps, el procediment habitual ha sigut carregar l'estrep en la seua part superior per a millorar l'estabilitat i dotar de major verticalitat les empentes. Amb aquest fi s'omplin els ronyons de les voltes fins a 1/3 aproximadament de la seua altura total amb la qual cosa s'aconsegueix reduir la seua llum, rebaixar-la i per tant fer-la més estable. D'aquesta manera, l'esveltesa límit i la grossària real aconsegueixen reduir-se.

Però és evident que un farciment de terra pot produir certes empentes actives, la direcció de les quals depén de l'angle de fricció i de la inclinació de la superfície, entre altres factors.

Es poden construir, doncs, voltes de fàbrica molt primes (1/100 del radi de curvatura) sempre que siguen rebaixades o que, a partir del lloc en què apareixen les traccions, existisca un resistència a les empentes (farciments i envans transversals fins a 2/3 d'altura). Els antics constructors reduïen la grossària de les cúpules en la seua part superior regruixant la pròpia volta a partir de la meitat de la seua altura.

La resistència també és pot obtenir per mitjà de tirants d'elements lignis o metàl-lics que treballen a tracció. 
L'arc de maó s'empra freqüentment com a element resistent en la coronació d'obertures. És un element acuradament traçat i muntat a fi d'alliberar espai en reemplaçar eficaçment el mur o la biga.

Destinat a suportar esforços importants de compressió transmesos per les fàbriques o altres elements constructius, l'arc està realitzat amb materials rígids i regulars per a transmetre els esforços rebuts als muntants o estreps.

Molt utilitzat en edificis monumentals i artístics, es troba també molt present en l'arquitectura de l'habitatge tradicional.

Tipològicament n'hi ha de dos tipus, els realitzats amb maó de pla i els adovellats o a plec de llibre. Els primers s'executen de la mateixa manera que es col-loca la rajola per a construir l'aparell de qualsevol parament -en horitzontal, al llarg o al través-i són més senzills d'executar que el segon, -en vertical, a rosca o sardinell- ja que el gruix de les juntes no varia en funció de la disposició radial de la rajola col·locada de pla.

Les variacions a l'execució i traçat dels arcs de mig punt, rebaixats i apuntats, més comuns en les obres de carreu, s'obtenen també i amb més facilitat amb la tècnica de la rajola, la qual permet allunyar-se de geometries simples, treballar sense cintra $i$, en funció de la destresa del constructor, aconseguir noves formes de resoldre la transmissió d'esforços en els paraments. Algunes variacions poden ser els arcs peraltats, rampants, penjants, de ferradura, etc.
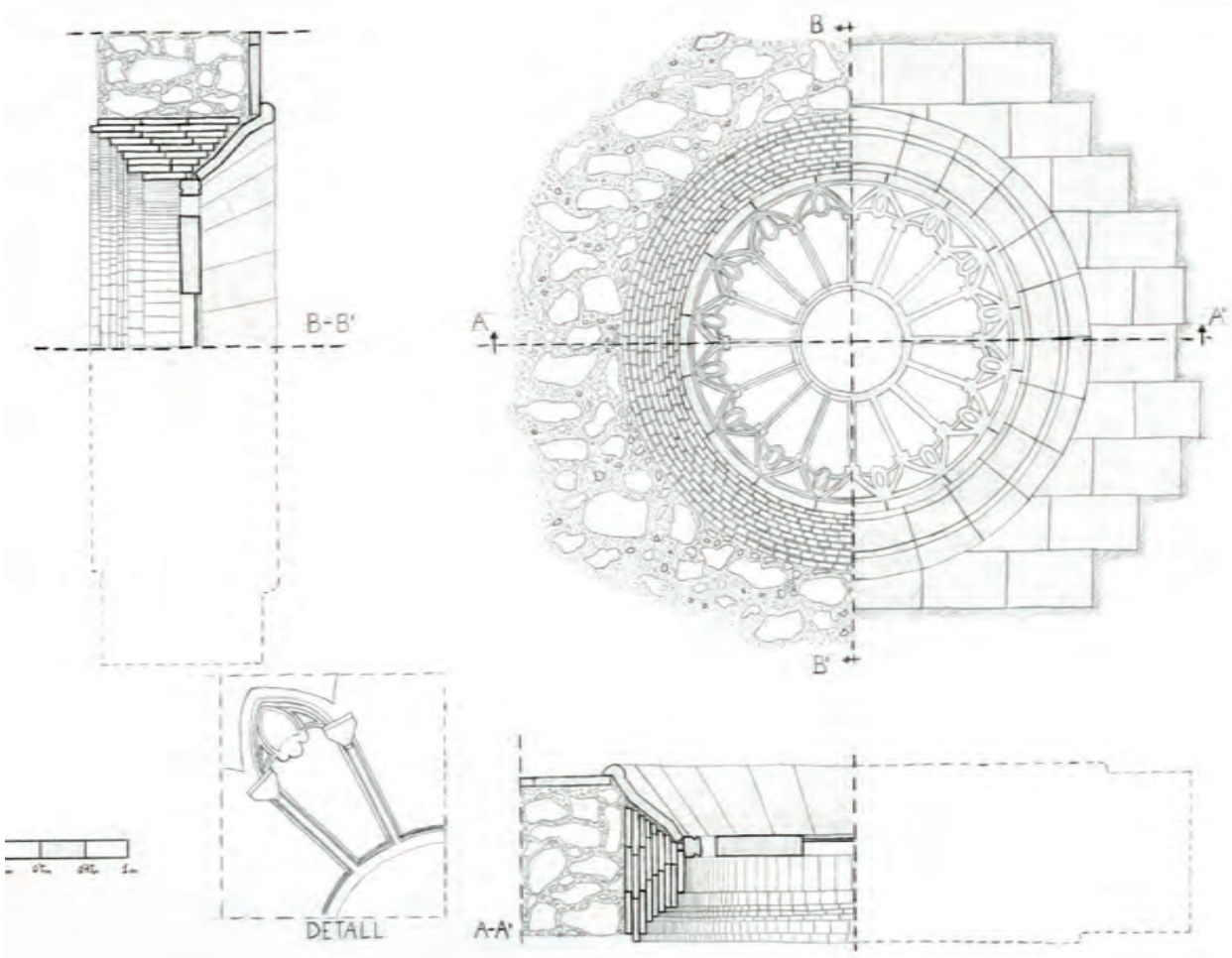

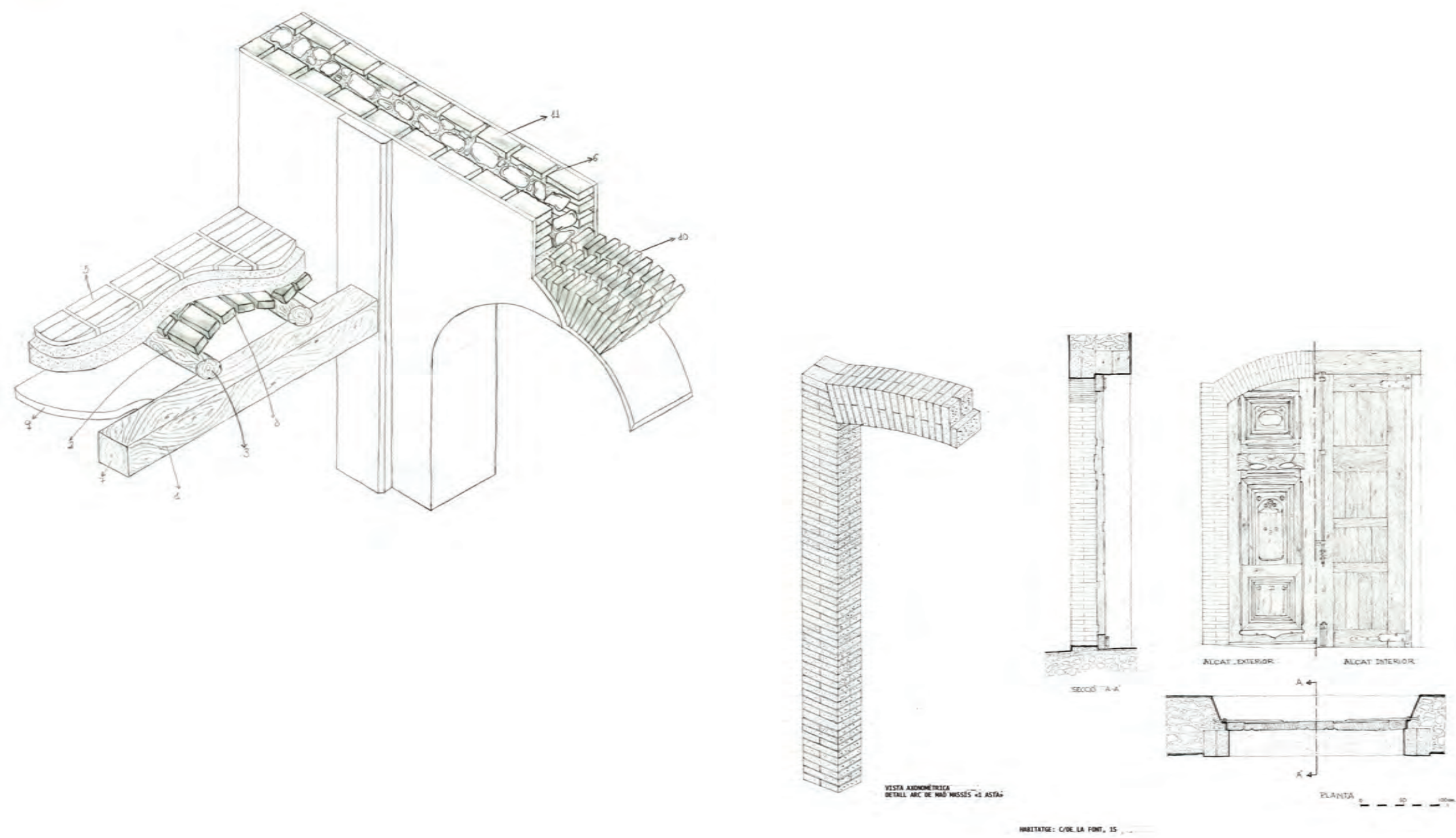


\section{Volta}

La condició primordial i rigorosa que cal a l'hora d'iniciar la construcció de qualsevol classe de volta és la de tenir tots els elements de suport correctament disposats per a contrarestar les empentes horitzontals que s'hi produeixen.

Una vegada complida aquesta condició i després d'haver muntat les bastides, s'han de traçar totes les marques o encontres de la volta amb les parets i procedir a la col-locació de la cintra, si procedeix, en el lloc corresponent. Segons els casos, serà convenient obrir regata en el parament on recolzar el primer full per a millorar la trava del conjunt i descarregar part de les empentes.

La dificultat en la construcció de les voltes de maó de pla està en la formació del primer full, ja que l'execució de la resta de fulls és més senzilla i poden fer-los paletes menys especialitzats. El primer es pot executar amb arcs o anells, segons siga la forma de la volta. Pel poc pes de la rajola i l'ús de guix, un aglomerant de ràpid enduriment, en alguns casos es pot fer la primera rosca a l'aire, és a dir, sense cintra, tan sols amb l'ajut de plantilles o guies. Les voltes es realitzen de dues o tres rosques, encara que també amb un sol full s'han cobert espais de grans llums.

Els maons, plans i rectangulars, han d'integrar-se al conjunt de l'arc o anell, si és possible, sense retoc de les arestes. Segons siga la curvatura, s'aparella col·locant-lo al llarg o a través però, si la forma rectangular de la peça no pot ser mantinguda en certs encontres, s'ha de retallar donant-li sempre formes poligonals. No cal un gruix excessiu en les juntes de morter perquè això retarda el seu enduriment i comporta lentitud en l'execució. Cada maó ha de quedar perfectament col-locat per a rebre'n els següents.
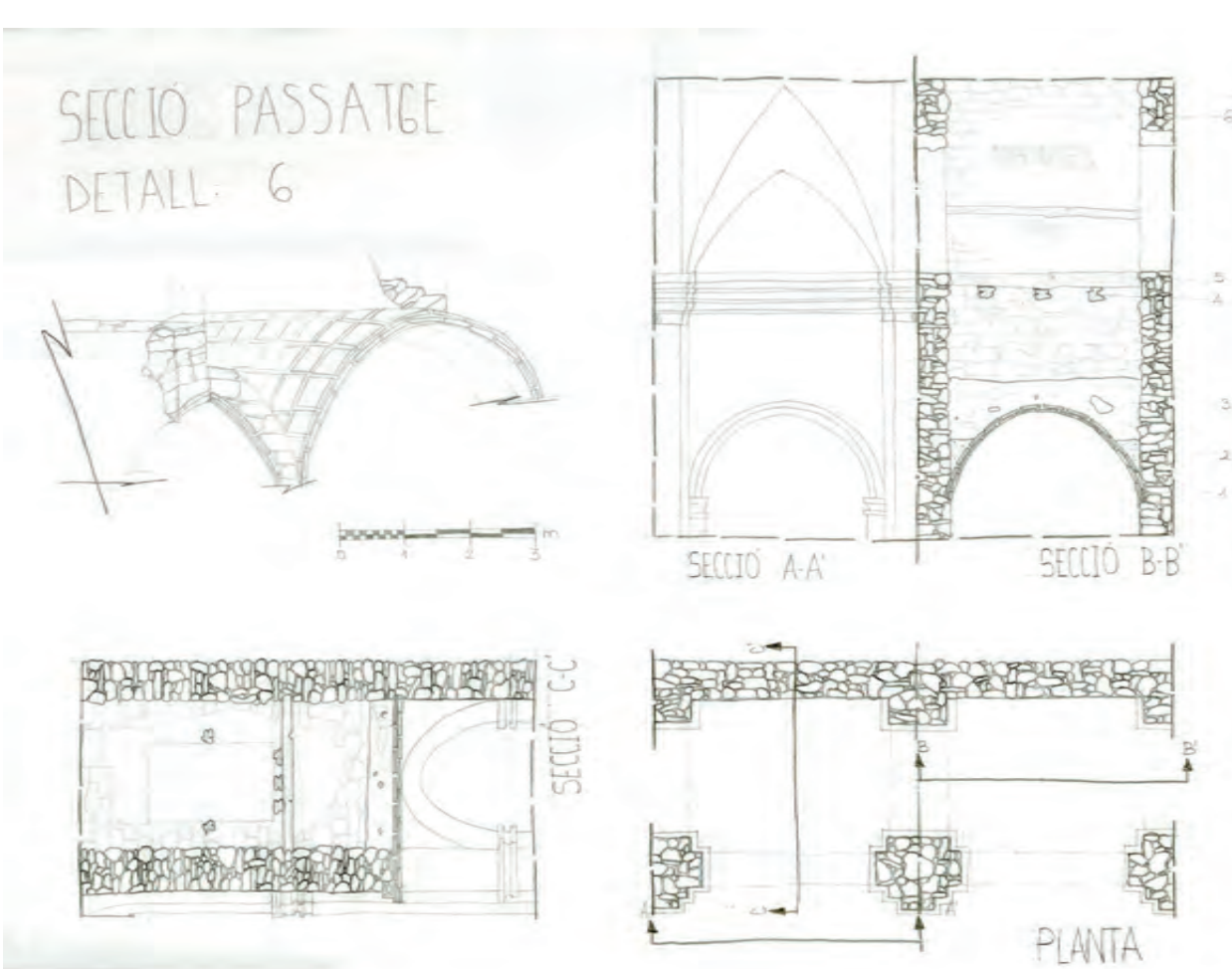


\section{Revoltó}

Es denomina revoltó a la volta que executada entre dues biguetes cobreix l'espai entre aquestes com a solució d'entrebigat d'un forjat. Hi ha, bàsicament, dues varietats de revoltons. La que es feia amb una estructura auxiliar de llistons de fusta que conformava poligonalment la volta, a manera de cintra, sobre la qual s'abocava un morter d'algeps fins a enrasar amb la cara superior de les biguetes, moltes vegades de secció rodona, aconseguint així un pla uniforme. Pel ràpid enduriment del guix, la cintra es podia recórrer al moment per a executar la continuació del revoltó o la resta de la crugia.

L'altra solució, posterior a la descrita, consistia en la realització de la volta amb maons prims lligats amb algeps, executada per arcs transversals a la direcció de les biguetes. La correcta col·locació de cada rajola s'aconseguia amb l'ajut d'una plantilla d'amplària semblant a la grandària d'un rajola i d'una llargària que poguera recolzar-se o clavar-se en les biguetes. Normalment aquestes voltes es realitzaven de dos fulls, encara que també és habitual fer-les d'un de sol.

La llum entre biguetes és variable i està directament relacionada amb l'escairada o grossor de la fusta; pot variar entre 36 i $70 \mathrm{~cm}$. Per poder recolzar el revoltó en la bigueta, en el primer cas, a les biguetes se'ls procurava o un dentat o un xicotet galze on agafar el morter. En el segon cas, la bigueta solia ser suplementada amb un llistó enrasat a la seua cara inferior on recolzar la rajola.

En ambdós casos, el cantell dels revoltons al punt central és molt prim, de $4-8 \mathrm{~cm}$.
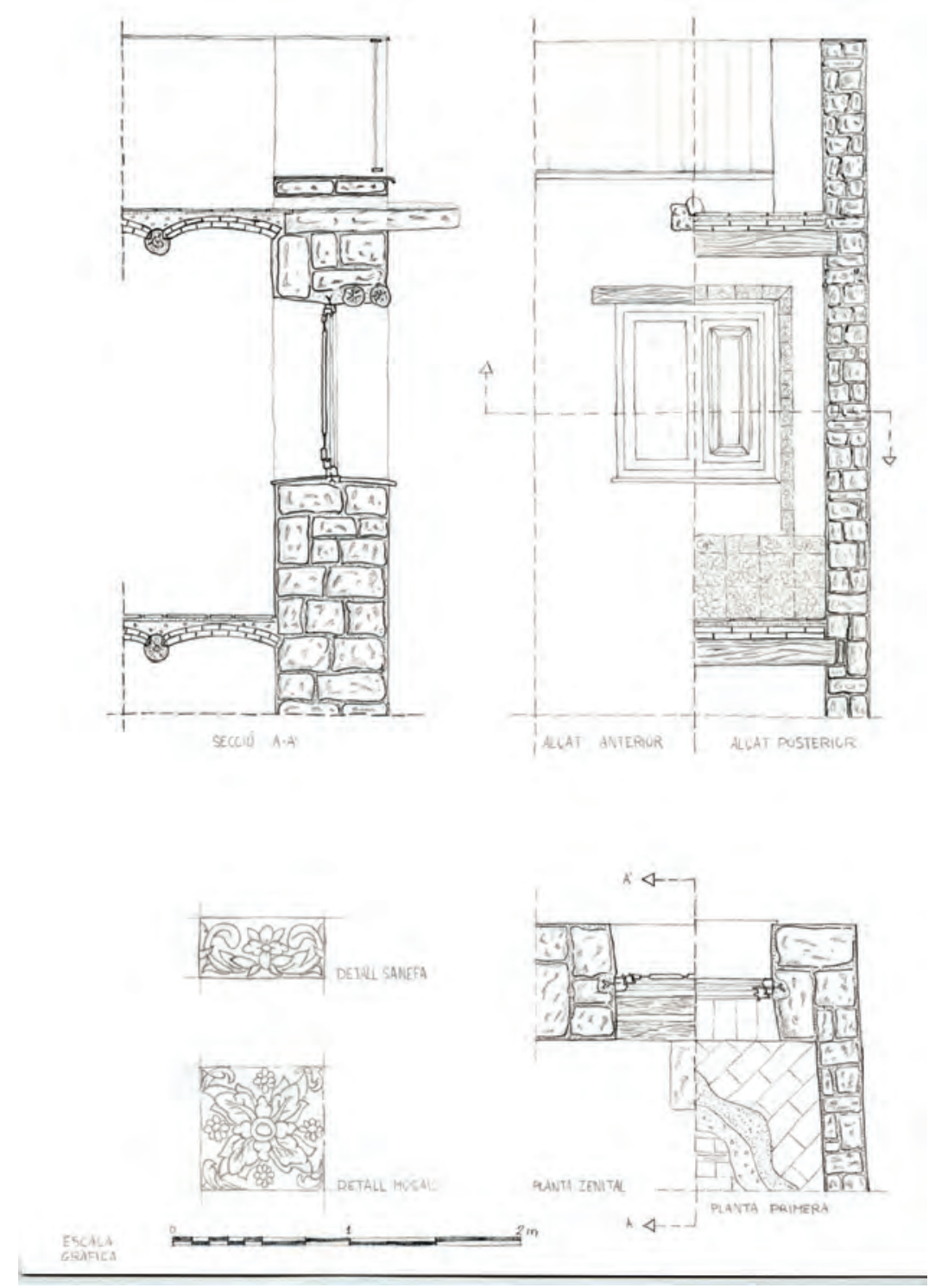


\section{FORJAT OUADRA \\ LAMINA 5}

1003 -

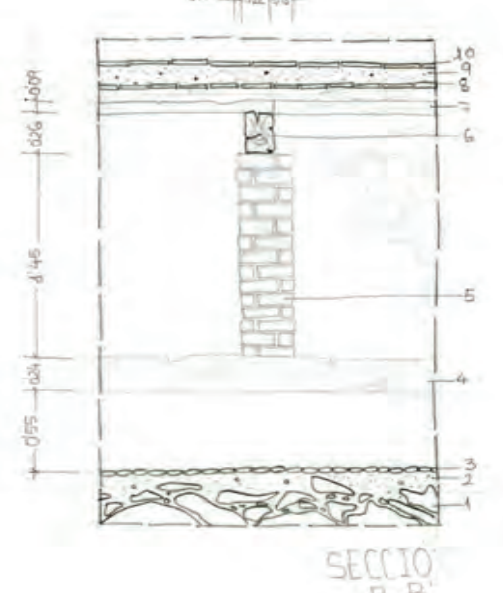

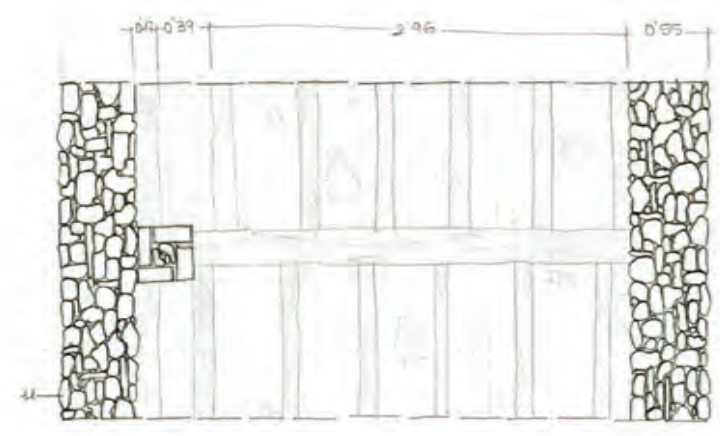

SECCIO

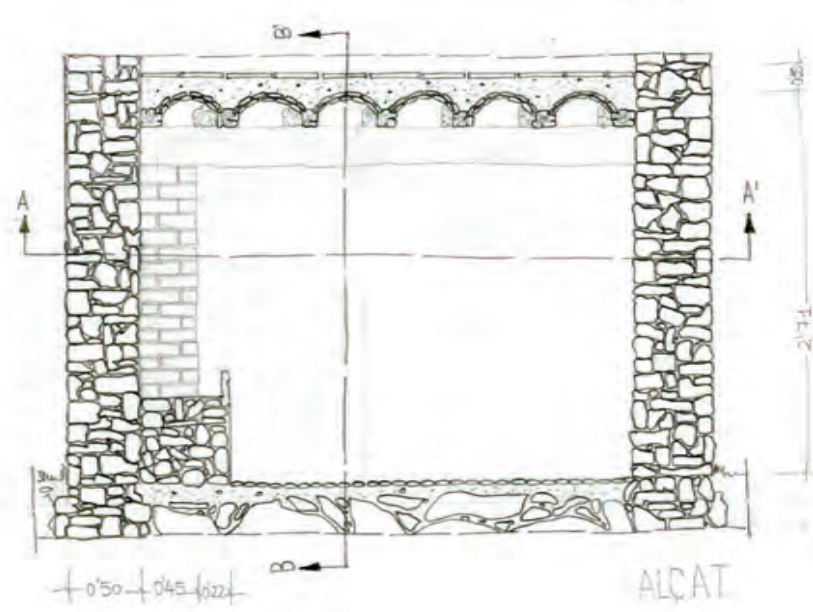

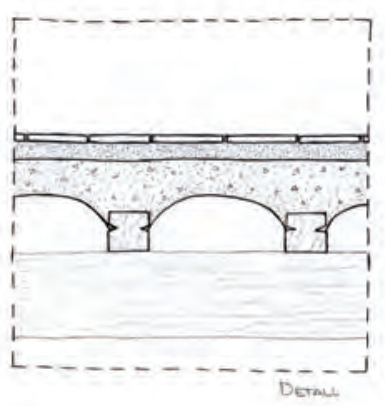

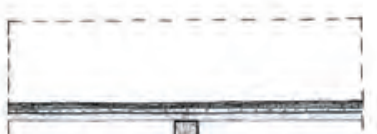

圆

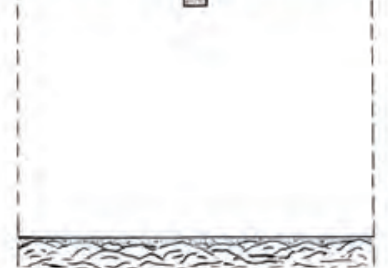

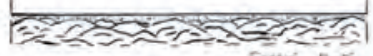

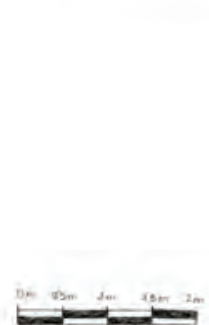

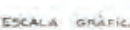
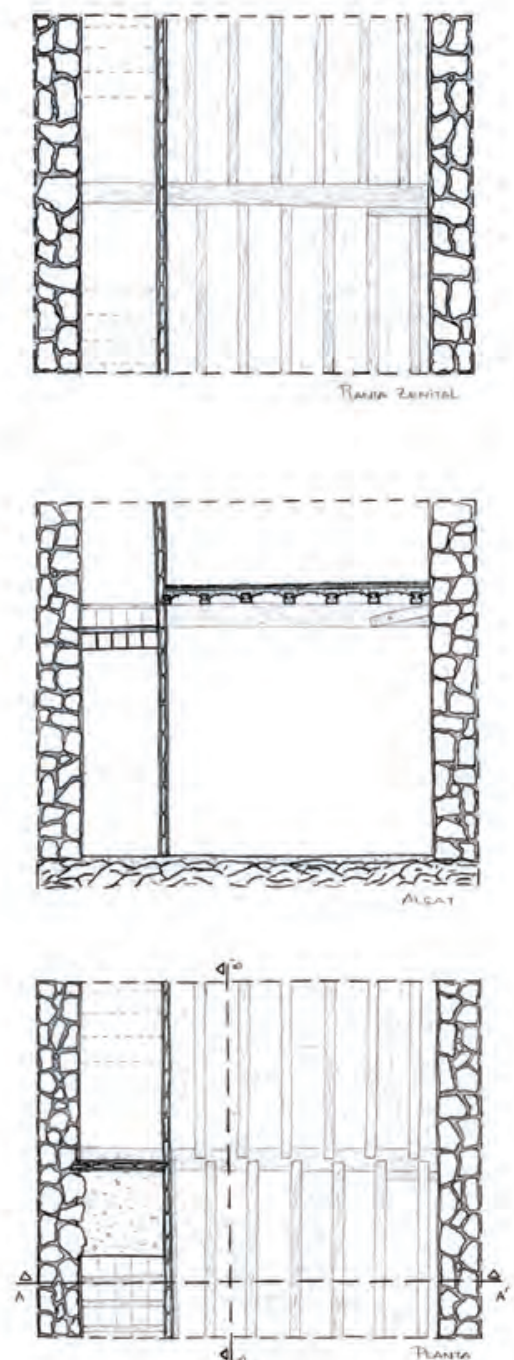


\section{Volta d'escala}

La realització de voltes d'escala amb maó prim en la construcció de l'estructura portant de les escales, ha estat molt generalitzada. Quan les escales són de diversos trams, es disposen generalment voltes independents que es traven i recolzen en les inferiors, aconseguint l'altura de les distintes plantes tram a tram.

Si visualitzem la volta per una secció transversal, veurem que la generatriu és recta en el cas de les escales contínues de caragol, mentre que ho és lleugerament arquejada, i amb inclinació cap als murs de la caixa de l'escala, en les realitzades per trams. Les generatrius s'inclinen contra la paret formant el capalçat. En sentit longitudinal, les directrius de la volta han de ser necessàriament corbes.

Per al traçat de una volta d'escala es dibuixa primerament la curvatura en els murs de la caixa d'escala. Aquesta operació pot fer-se de vàries maneres: «a sentiment», amb ajuda d'un llistó flexible de fusta, o amb una corda pel sistema conegut com la «catenària». Sobre el traçat no convé fer una regata que siga profunda, ja que si la rajola hi penetra en excés pot impedir qualsevol moviment del conjunt i produir danys en la volta.

Les voltes d'escales es realitzen amb tres rosques, encara que és habitual fer-les amb dues. En la primera rosca, les rajoles s'uneixen amb guix i sense ajuda de cintra, col-locant-hi les restants amb morter de calç o ciment, i a trencajunts en relació a la rosca inferior.

La volta del primer tram d'una escala recolza generalment en un massís amb el seu corresponent fonament i, per l'altre extrem, en el mateix mur de la caixa de l'escala. En la realització del segon tram, la primera rosca recolzarà sobre la segona rosca del tram inferior i així successivament.

En el disseny de les voltes s'han de tenir en compte diverses circumstàncies com ara:

- Limitar les sobrecàrregues, donant-hi poca fletxa.

- Preveure que la volta, a més de servir de suport als escalons i replans, ha de rebre la volta superior.

- Buscar al màxim la simetria de càrregues a un costat i a l'altre del punt més pròxim entre la directriu de l'arc i la línea inferior d'escalons. 

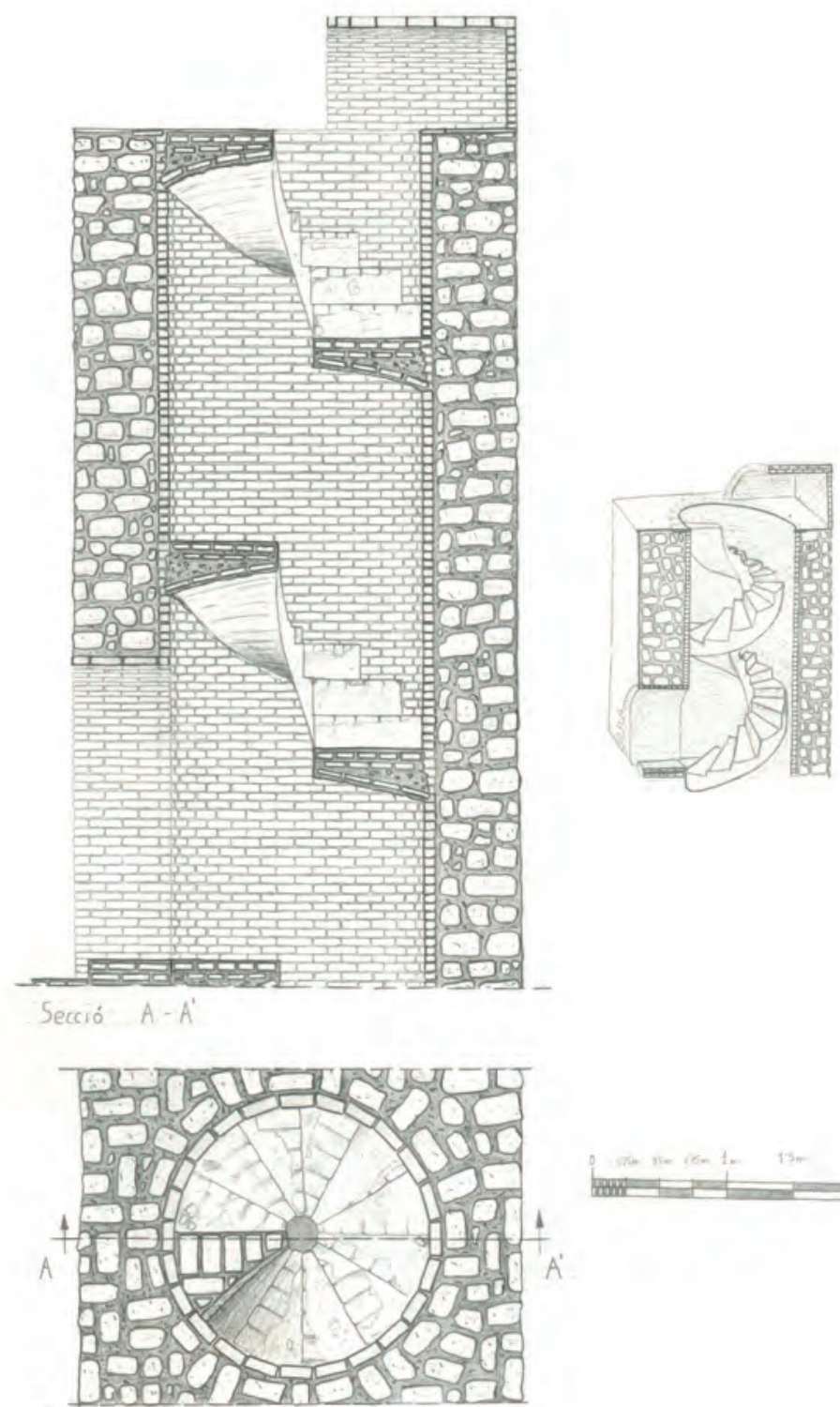

Seccio: Hontzonta?

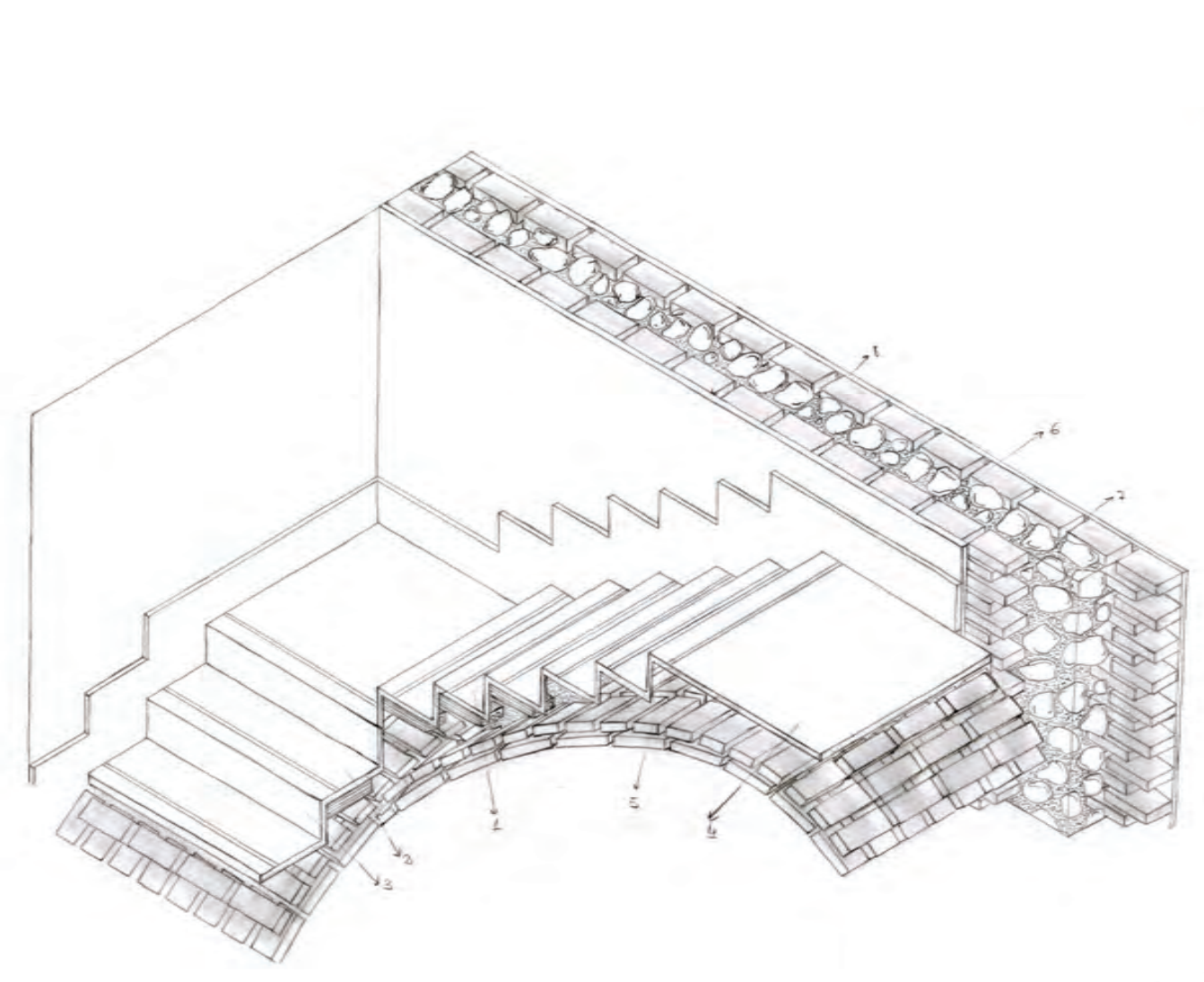



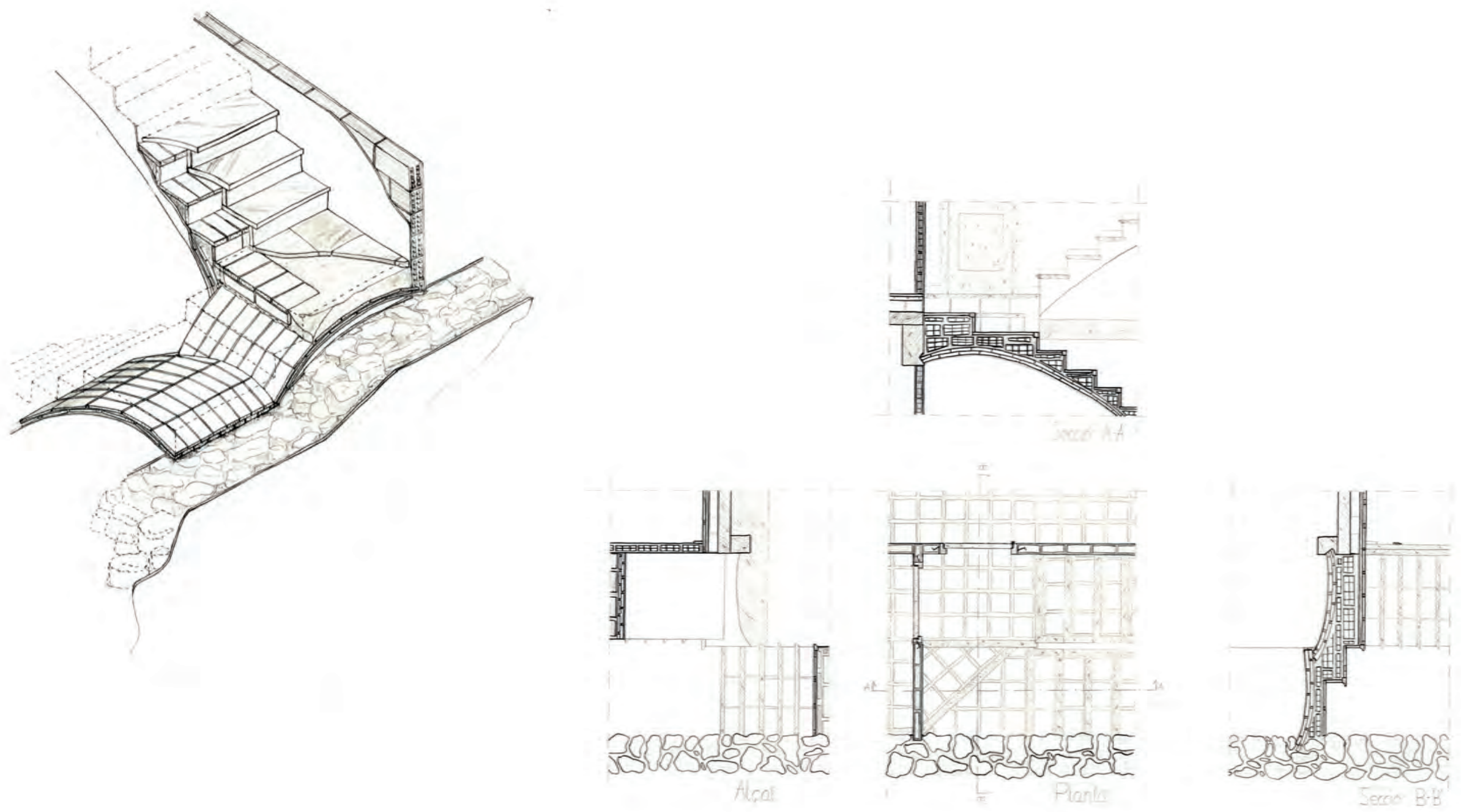


\section{Cúpula}
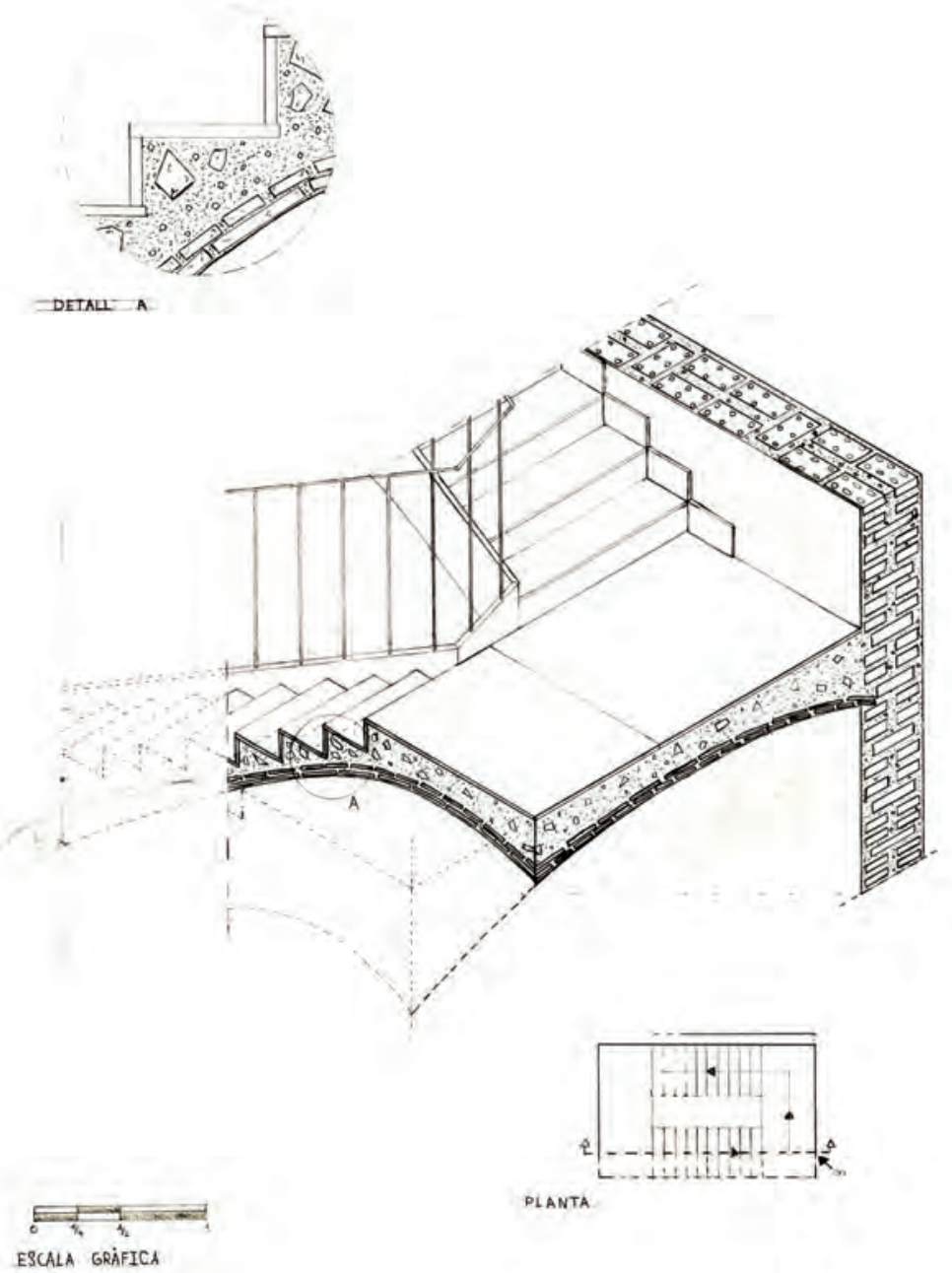

Les cúpules són estructures de cobriment - mitja taronja, bufada, peraltada...- que es realitzen per a cobrir espais de planta poligonal, normalment quadrada.

Poden realitzar-se sobre arcs o sobre murs que delimiten l'espai a cobrir. En les unions entre els murs es realitzen les trompes, elements constructius triangulars còncaus construïts en volada que serveixen per a passar d'una planta poligonal a un altra amb el doble de nombre d'arestes. Si la cúpula es construeix sobre arcs, es requereix la construcció de petxines, element en forma de triangle esfèric que serveix per a passar d'una planta quadrada a una circular.

Les qualitats de la rajola $\mathrm{i}$ el ràpid enduriment del guix amb què es colloquen les peces fan prescindible l'ús de la cintra en la realització de les cúpules.

Es farceix o es reforça el primer terç inferior (ronyons de la cúpula) per a contrarestar les empentes que es transmeten des de la part superior de la cúpula en forma radial. Aquest farcit té per missió la reducció de la component horitzontal de l'empenta sobre els suports, en augmentar la component vertical. Si els esforços horitzontals no són contrarestats, la cúpula probablement es trencarà horitzontalment pel seu primer terç.

Una altra tècnica de construir cúpules consisteix a confeccionar els arcs pertinents (nervis) i després cobrir els panys (plementeria) per mitjà de rajola colllocada de pla, visualitzant-se les nervadures en una imatge semblant a un paraigua. 
Tant les cúpules com les voltes normalment queden recobertes per una capa de revestiment i resulta complex analitzar el material que les constitueix.

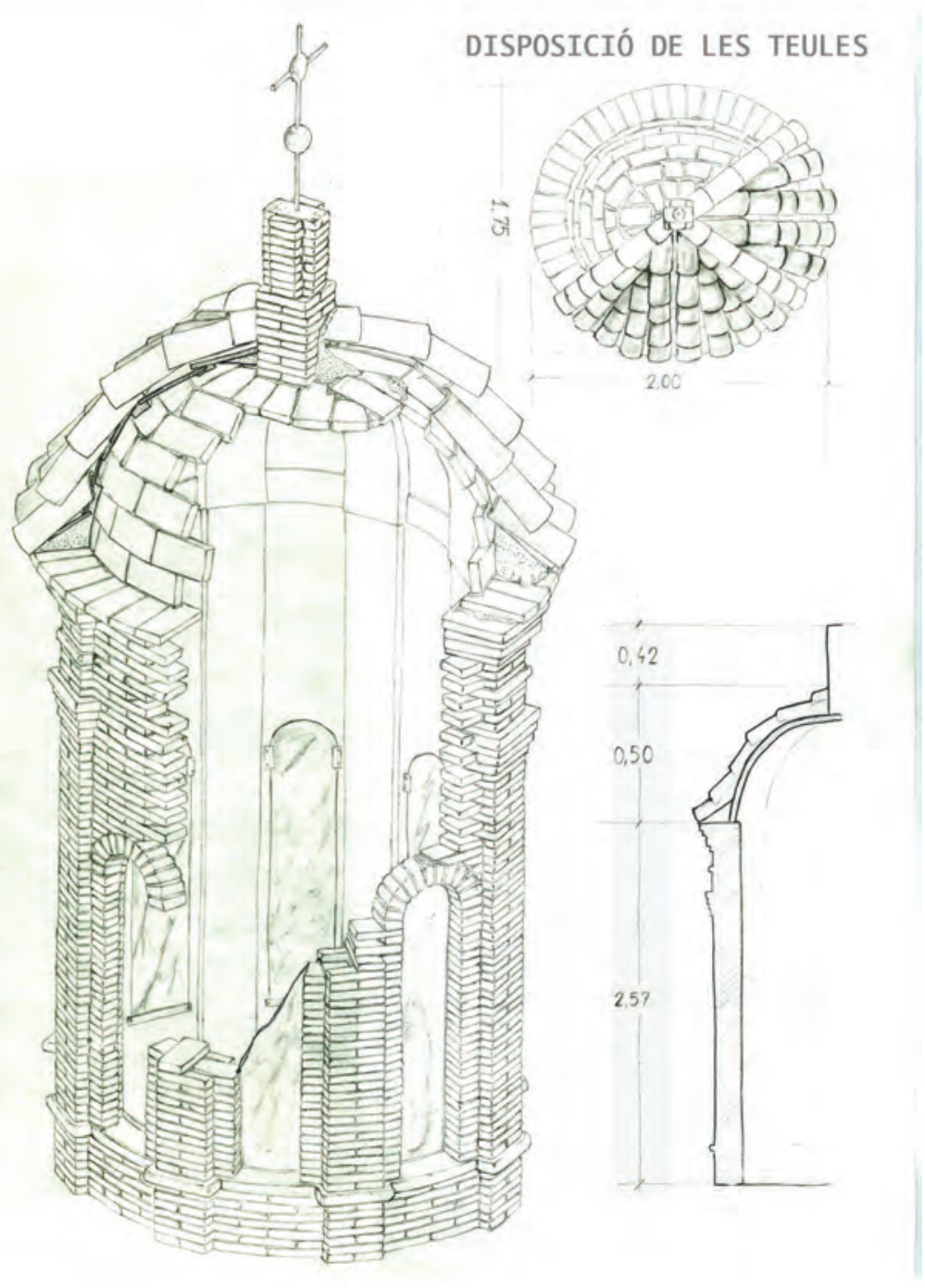




\section{Entramats lignis}

\section{Forjat}

Els forjats són els elements estructurals, generalment horitzontals, que transmeten el seu propi pes i les càrregues que reben als elements portants verticals. Es componen de nervis i biguetes, tradicionalment de fusta, que són els elements resistents, i de l'element d'entrebigat, els revoltons que, una vegada farcits, ofereixen al conjunt l'aplanament per a rebre el paviment.

En ocasions les biguetes descansen sobre bigues de fusta. Aquestes són de característiques semblants a les primeres però de major esquadria. Depenent del tipus de fusta, de les càrregues a suportar i/o de la llum a cobrir, poden oscil.lar entre 20 i $30 \mathrm{~cm}$.

Les biguetes poden ser de secció rodona, quadrangular o rectangular. Una mida habitual entre les darreres es la de $8-15 \mathrm{~cm}$, però aquestes mides vindran en funció del tipus de fusta disponible o la llum a cobrir. Les biguetes poden transmetre les càrregues directament als murs, a un arc, o descansar sobre una biga de fusta, traslladant-hi les càrregues als murs -estructures verticals sotmeses a esforços de compressió.

El tercer component d'aquest conjunt és el que transmet les càrregues sobre les biguetes, alhora que dóna l'esplanació necessària per a servir de paviment o per al seu suport. En llocs on abunda la fusta és habitual la solució de collocar un entaulat de fusta clavada a les biguetes. El sistema més habitual a les terres valencianes, però, és el del revoltó, ja descrit en apartats anteriors.

A mitjan segle XIX els forjats de fusta van anar sent desplaçats per forjats amb nervis de perfils metàl-lics, però mantenint la concepció general del forjat. Amb el segle Xx sorgeix el formigó armat, emparant-se les primeres biguetes en la dècada dels anys trenta i de forma massiva a partir de mitjans del segle.

CC) Juan A. Garcia Esparza - ISBN: 978-84-695-8048-6

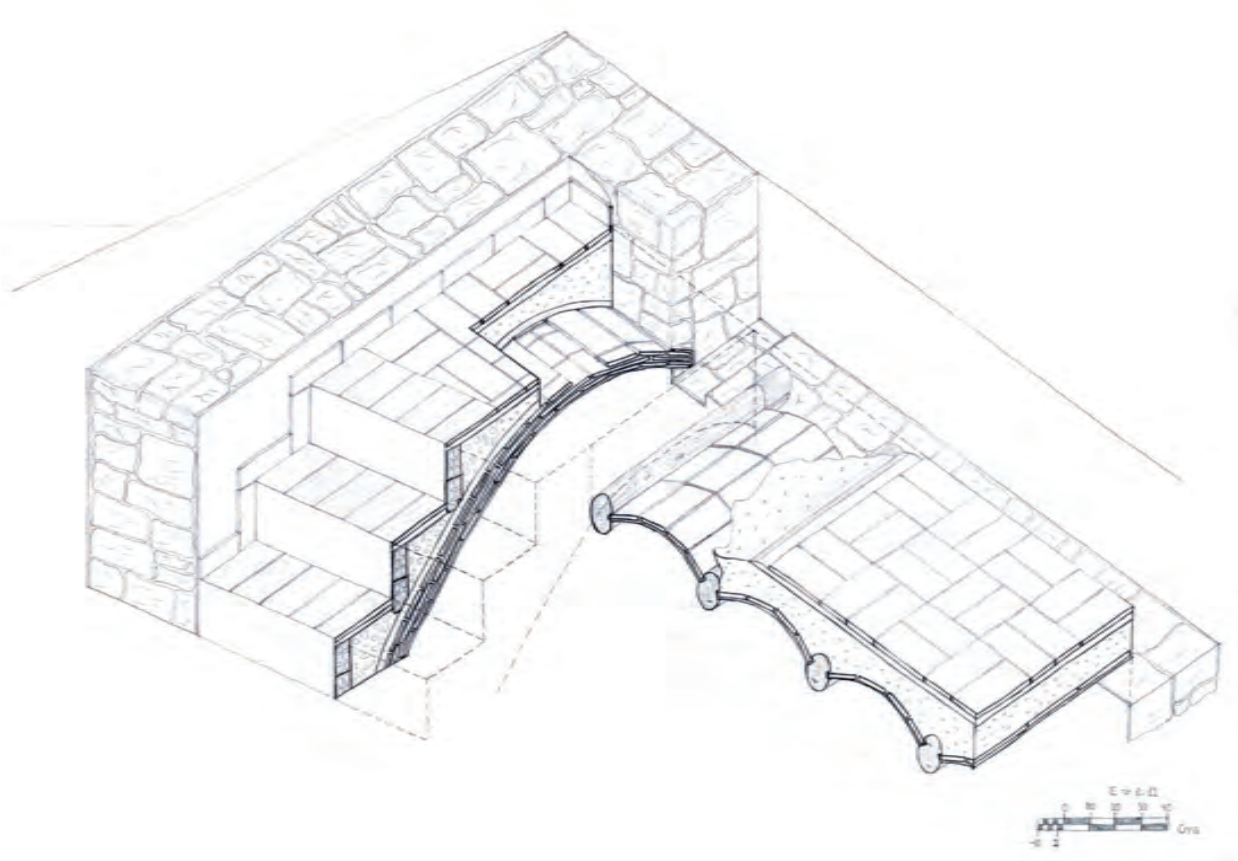

Construcció I, projecte. La mirada i reflexió sobre les tècniques constructives tradicionals - UJ - DOI: http://dx.doi.org/10.6035/Sapientia78 


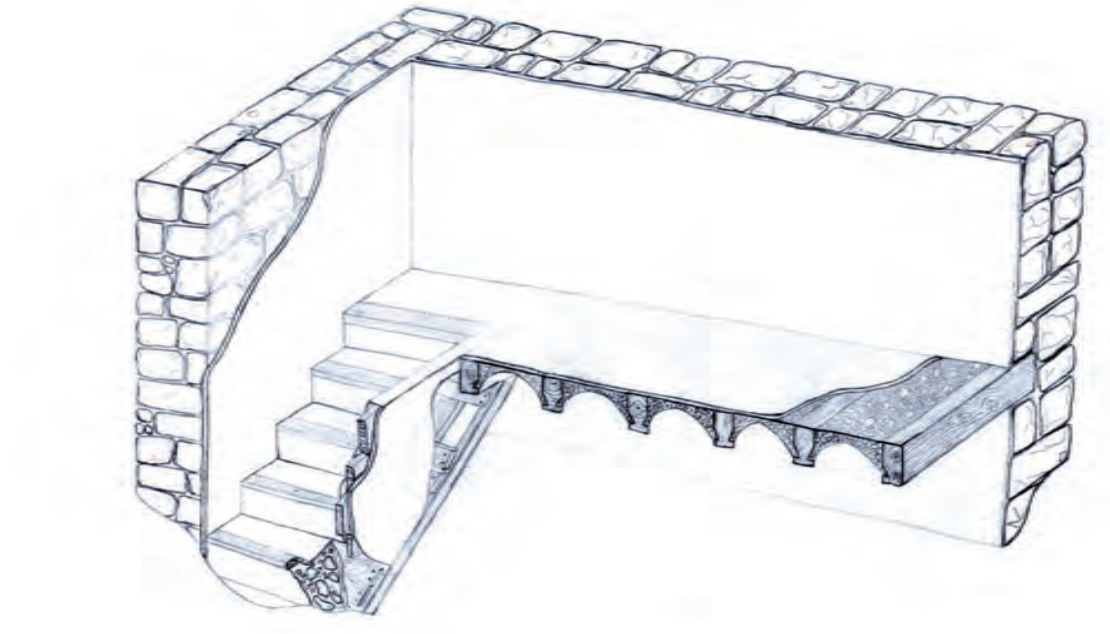

ENCONTRE ESCALA-FORJAT

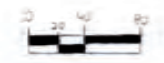

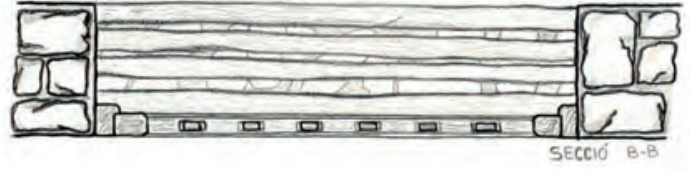
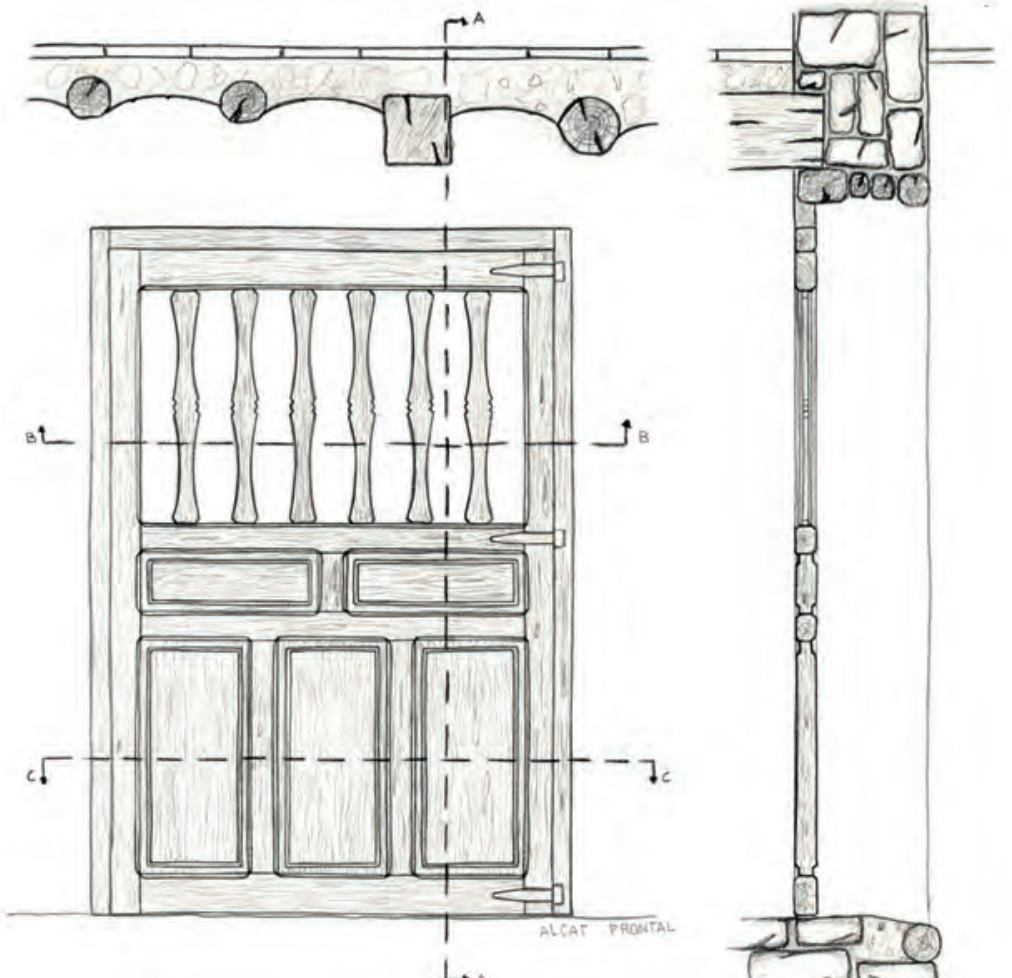

$\iota_{A}$

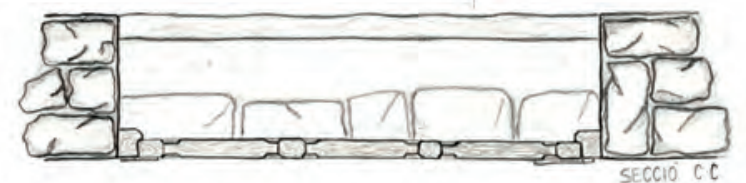

f 


\section{Escala}

Les escales realitzades amb estructura portant de fusta són freqüents en zones de muntanya on la disponibilitat d'aquest material va generalitzar aquesta solució enfront dels elements ceràmics, més immediats i barats en àrees del litoral, zones d'al·luvió on hi ha una bona aportació de sediments i argiles.

A diferència de les voltes d'escala, en l'estructura dels trams executats amb elements lignis el pendent és uniforme i rectilini, visualitzant-se els elements que la componen a l'intradós de l'escala.

Igual que les escales de volta de maó prim, aquestes fustes s'encasten en un massís en la seua part inferior, mentre que a la superior ho fan en un mur de càrrega $o$, el que és més habitual, subjectades a una biga amb claus de ferro -sempre en elements amb suficient resistència. Com succeeix en qualsevol tipologia d'escales, ambdós suports, tant el superior com l'inferior, eviten el desplaçament de l'escala -exerceixen de resistènciesdavant de la transmissió d'esforços deguts al pes propi i a la càrrega d'ús.

Els escalons s'executaven, des de la part inferior del tram a la superior, emprant una taula, col-locada en vertical i del mateix ample que el tram, que exercia d'encofrat per a l'abocament d'argamassa i enderrocs -restes d'obra. Sobre el primer escaló, una vegada endurit el morter, es continuarien executant la resta d'escalons.

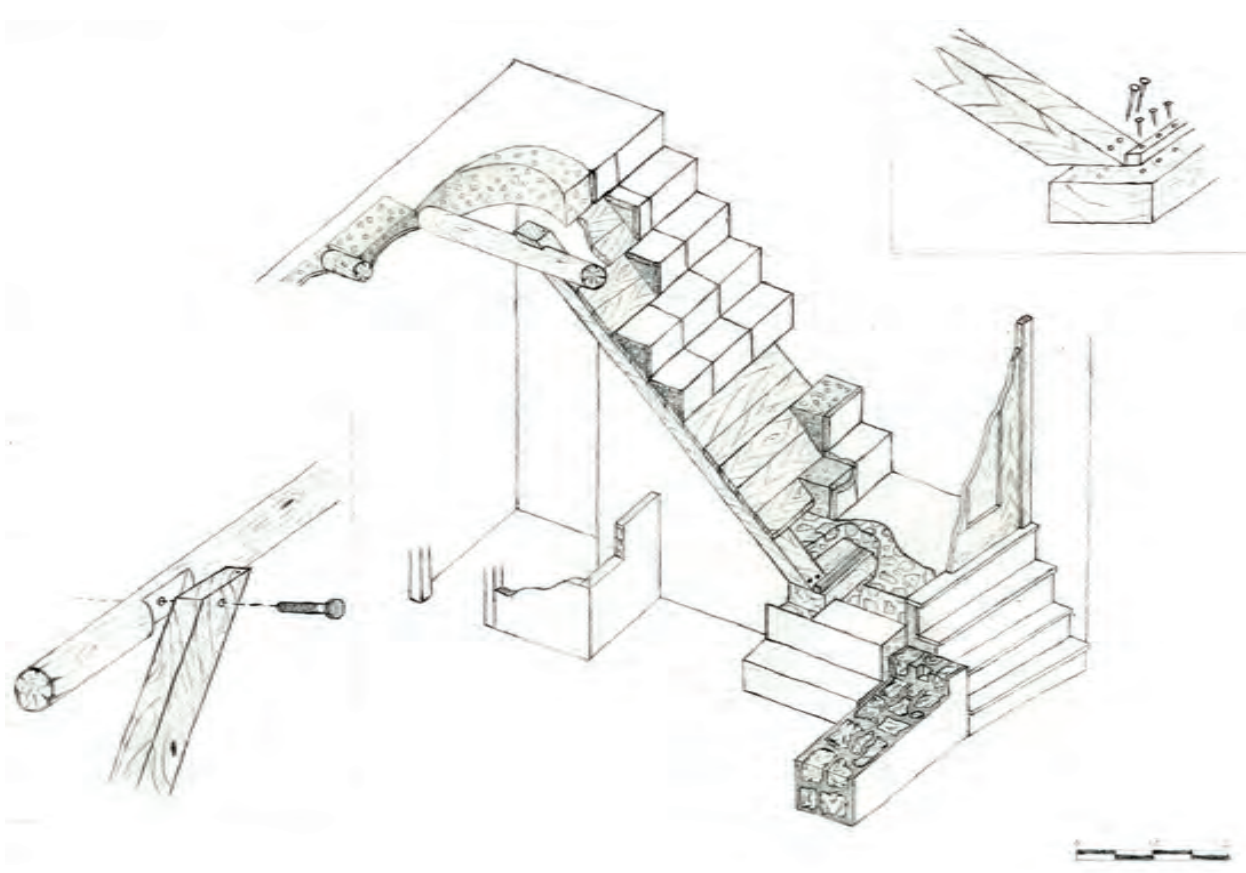



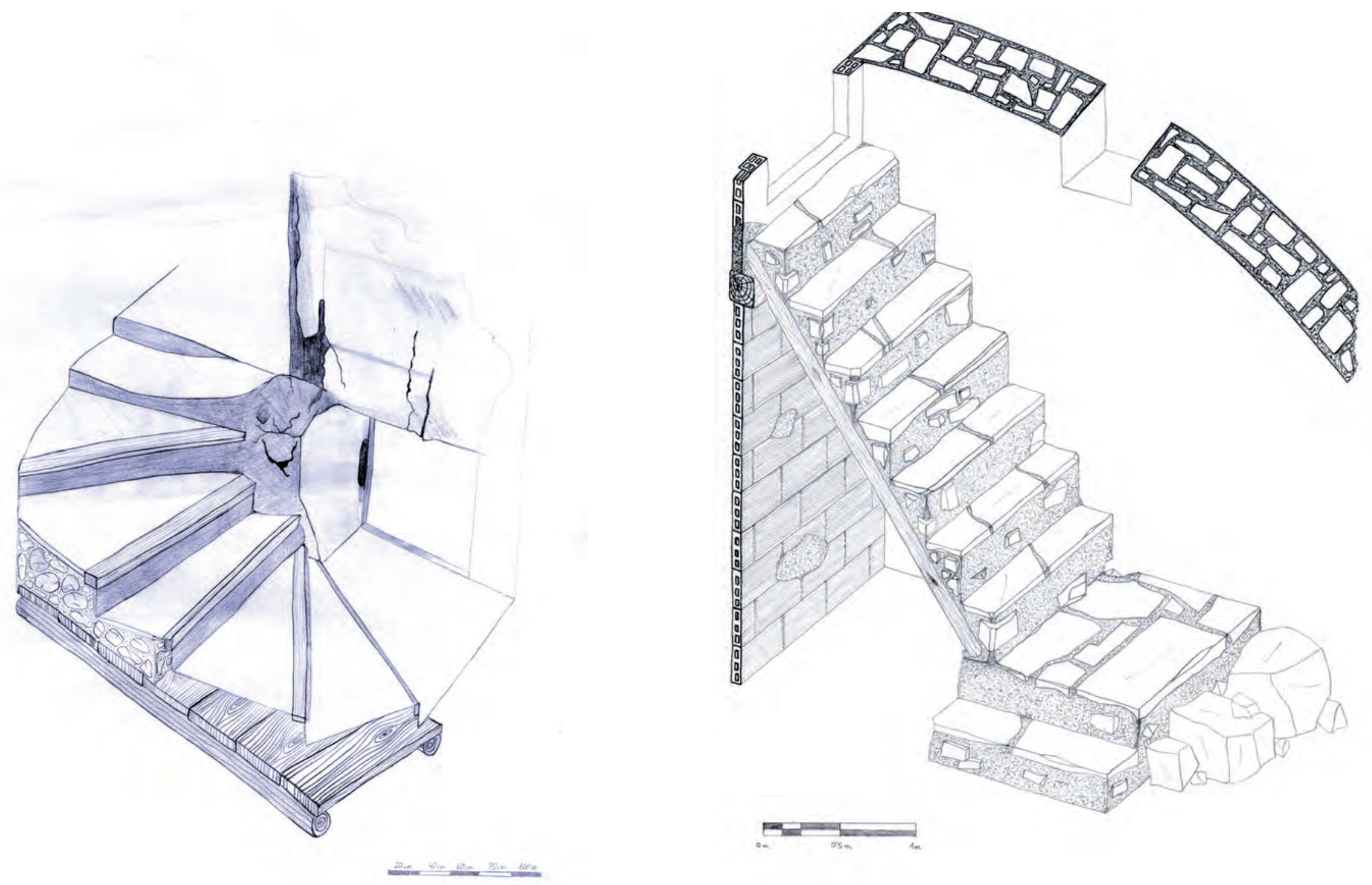


\section{Coberta - Aiguavés}

La forma i el sistema de construcció d'una coberta, vénen determinats, a més de per consideracions estètiques, per les necessitats pràctiques: donar fàcil eixida a les aigües pluvials i a la neu, aprofitament de l'espai com a lloc a ocupar, etc.

Les dues tipologies més comunes són la coberta inclinada i la coberta plana. En ambdós tipologies els entramats lignis són els que s'ocupen de la missió sustentadora.

En les cobertes inclinades, el nombre de vessants, la inclinació i el material de cobertura determinen l'aspecte final de la construcció. Les característiques de l'armadura de cavall responen a la tradició de l'encavallada senzi1la. El sistema més simple és el format només per corretges recolzades en els murs perimetrals i en la biga carenera.

La coberta es construeix amb un entramat unidireccional de cabirons de fusta, que no solen sobrepassar els $5 \mathrm{~m}$ de longitud, sobre el qual es clavetegen posts de fusta o canya de ribera trenada. Una altra solució més elaborada consisteix en la col-locació de llistons sobre les biguetes damunt dels quals descansen rajoles de teular unides amb pasta de guix. Finalment, sobre aquestes superfícies s'estenia un llit de fang o morter de calç com a base per a la collocació de les teules. Aquestes armadures a vegades obliguen a disposar tirants de fusta encastats en la paret. Els acoblaments són relativament simples: a mitja fusta, senzilles mosses, clavetejat o, a vegades, uns simples lligats.

En la majoria de les construccions agrupades la teulada sol ser a dues aigües amb carener paral·lel a la façana per a evacuar l'aigua sense afectar la vivenda veïna. La inclinació de la teulada acabada amb teula àrab varia entre les zones de baixes precipitacions $(25 / 30 \%)$ i les d'altes precipitacions i innivació $(30 / 40 \%)$ perquè a major inclinació, més ràpidament s'expulsa la neu i l'aigua de pluja, evitant així el perill d'afonament i les filtracions.

(c) Juan A. García Esparza - ISBN: 978-84-695-8048-6

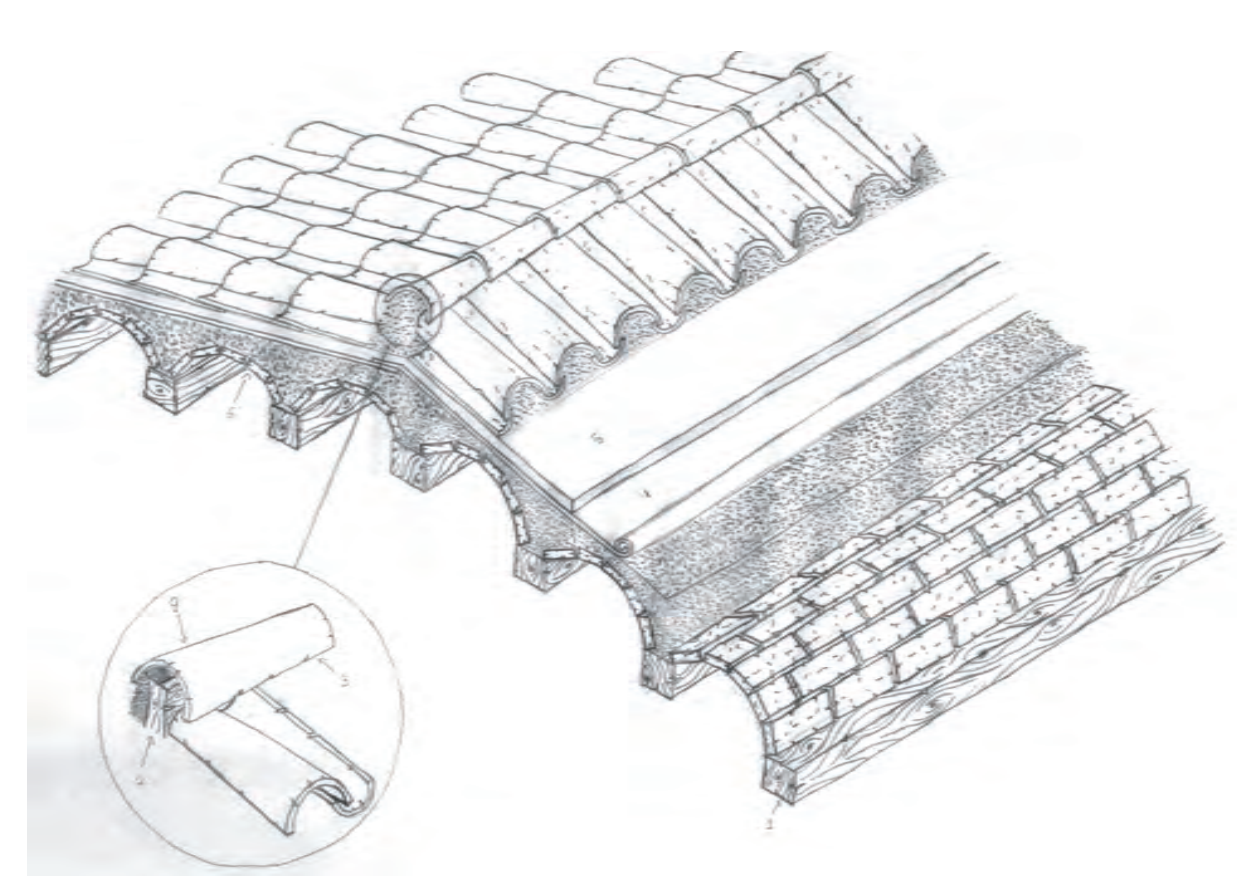



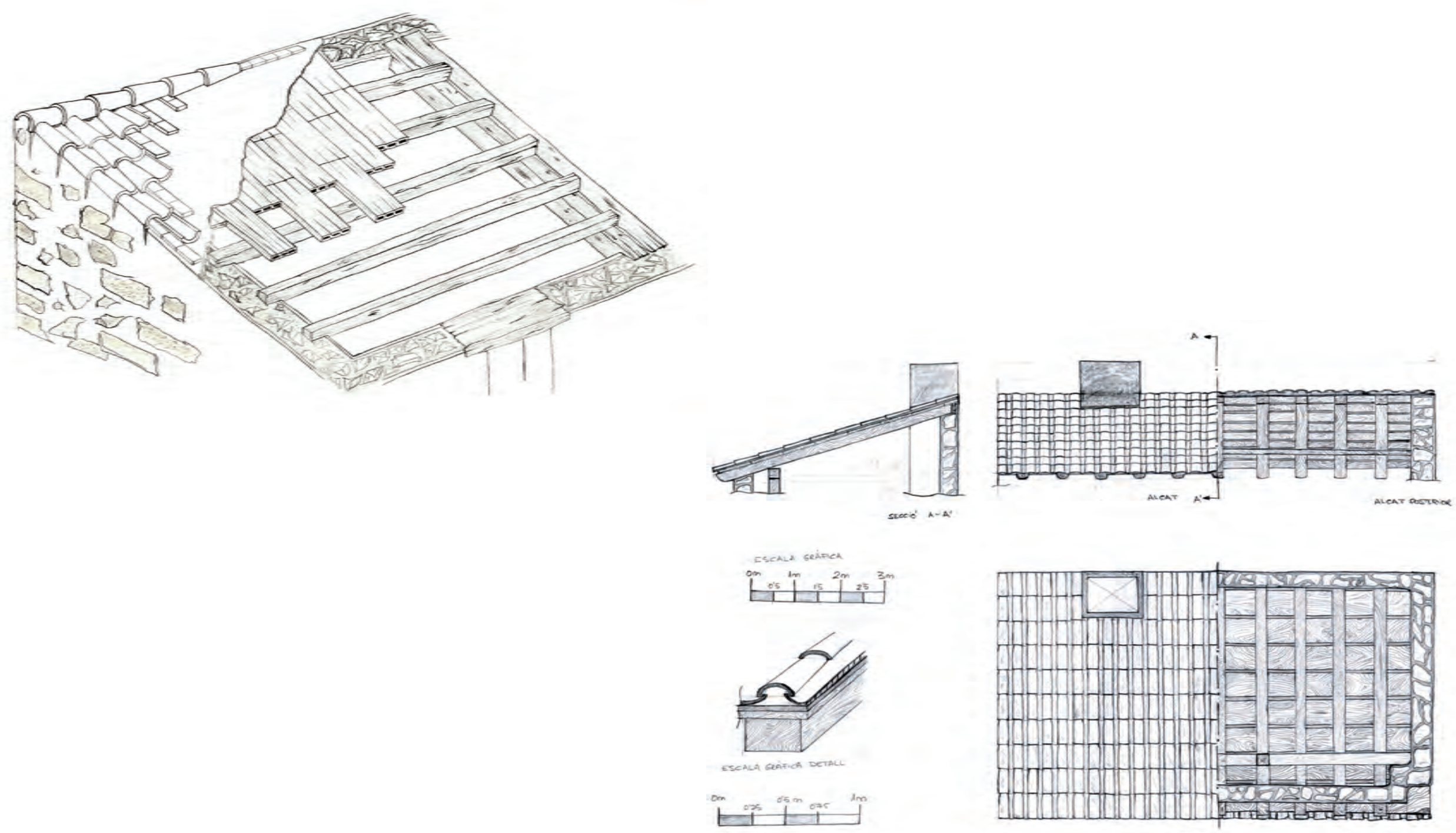

Rama.

zowrat 


\section{Coberta - Ràfec}

El ràfec és el perímetre horitzontal de la teulada, la part més baixa que sobreïx del parament del mur per a protegir la façana de l'aigua de la pluja.

En la majoria dels casos són de construcció senzilla, construits amb maó prim col-locat de pla formant-se una o dues filades. En ocasions s'intercalen filades de teules i entre les de rajoles o d'altres de rajoles en diagonal. De vegades, amb un afany de dignificar la casa, es pinten aquests elements, la majoria dels casos amb traçats geomètrics.

Aquestes són solucions més pròximes a les cornises en tant que els seus elements són més aviat una prolongació del mur en la seua coronació.

Un altre tipus de ràfec és l'executat amb la prolongació de les bigues de l'aiguavés de la coberta fins que depassa la vertical de la façana sobre les quals es claven uns posts de fusta o un canyís, que reben les teules.

Un altre tipus, pot ser més complex que els esmentats anteriorment, són els que es construeixen amb permòdols independents de les bigues de la coberta. Aquests és col-loquen completament horitzontals i subjectats a una biga situada en el mur, a manera de dorment, que evita la bolcada del ràfec. En la cara inferior del ràfec, sobre els permódols, es col·loquen posts de fusta, decorats, en ocasions, amb frisos, sanefes i escacats tallats en la fusta, anomenats cassetonats. D'aquesta decoració no s'escapen, normalment, els elements estructurals del ràfec.
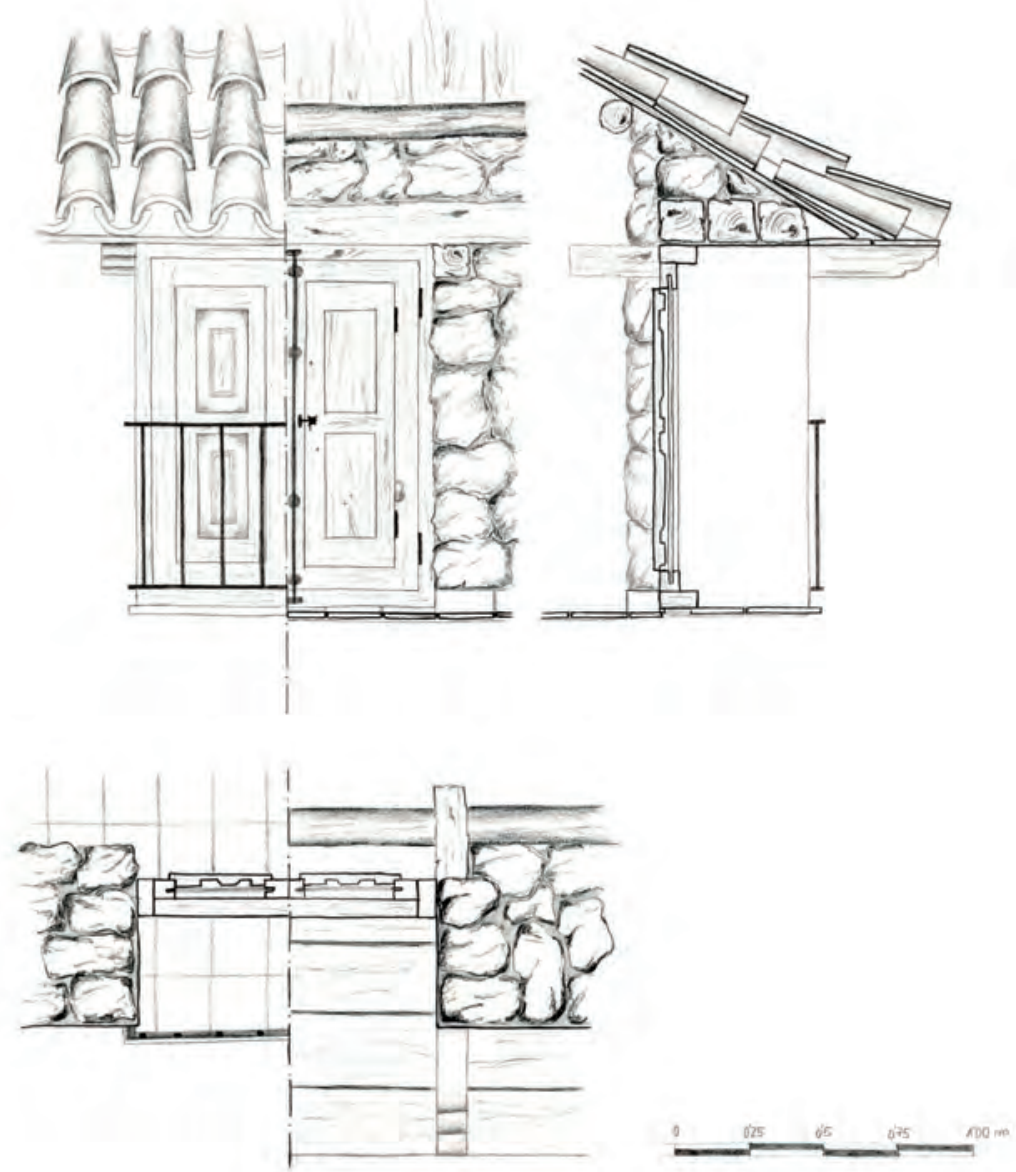


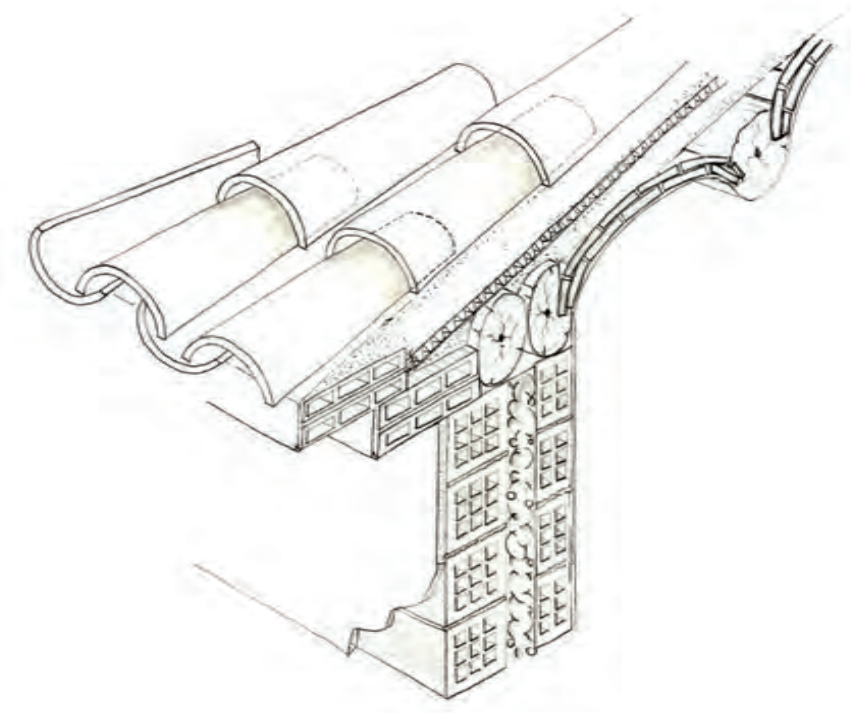

DETALL CONSTRUCTIU COBERTA
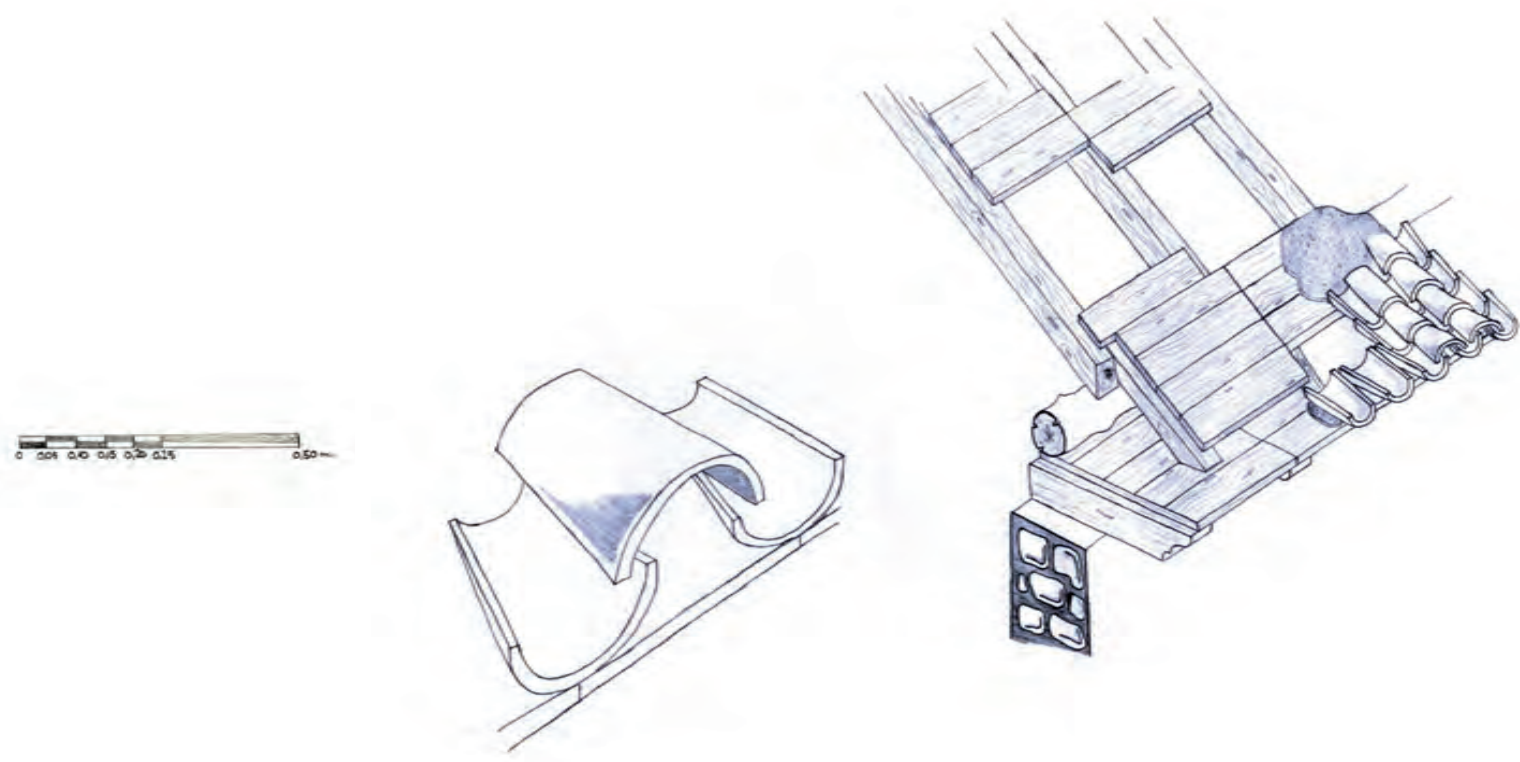

图

COLLOCACIO CORRECTA
DE LES TAULES

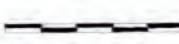




\section{Cobertura}

En la construcció primitiva les cobertes es resolien amb una cobertura de palla o postetes de fusta, i en ocasions lloses de pedra. Mentre la palla es collocava sobre un pla conformat per un entramat de canya trenada, els altres dos materials descansaven directament sobre l'estructura de la mateixa coberta.

La terra argilosa cuita s'ha emprat des d'antic en el recobriment d'edificis per ser l'argila un material mal·leable, i una vegada cuita, resistent a la intempèrie. Les teules corbes (o teula àrab), les emprades en l'arquitectura tradicional, malgrat ser permeables a l'aigua confereixen impermeabilitat a la coberta per la disposició d'encavallament en què s'hi posen i el seu pendent.

Les taules es col-loquen en les posicions de riu i cobertora abocant l'aigua una sobre l'altra, assentades sobre un llit de fang estés sobre un entarimat de fusta o un canyís clavat a les biguetes. En la majoria dels casos s'hi posen en sec, reservant la col-locació amb morter pobre en calç o simplement amb fang per als vessants més exposats als vents dominants, per a les teules de les vores de la teulada i per a les de la carenera. És habitual trobar lloses de pedra sobre el perímetre de la coberta amb la funció d'evitar l'aixecament de les teules per l'acció del vent.

Per a la disposició de les teules caldrà replantejar les filades dels rius i cobertores des de la vora del ràfec. Una vegada repartits els rius, es comença a teular en sentit ascendent del pendent.

Per la forma i tonalitats es poden distingir clarament les teules manufacturades o antigues de les industrials. Les primeres són més apreciades per la irregularitat de les seus tonalitats i per l'obturació dels seus porus a causa dels anys d'exposició a la intempèrie, amb la qual cosa es doten d'una major impermeabilitat.

La coberta plana, amb pendents inferiors al 5\% per a evacuar l'aigua, inicialment tenia com a protecció la terra argilosa. Posteriorment, el material de protecció ha sigut un entaulellat de petites peces ceràmiques, una tipologia de coberta pròpia del litoral mediterrani.

(C) Juan A. García Esparza - ISBN: 978-84-695-8048-6
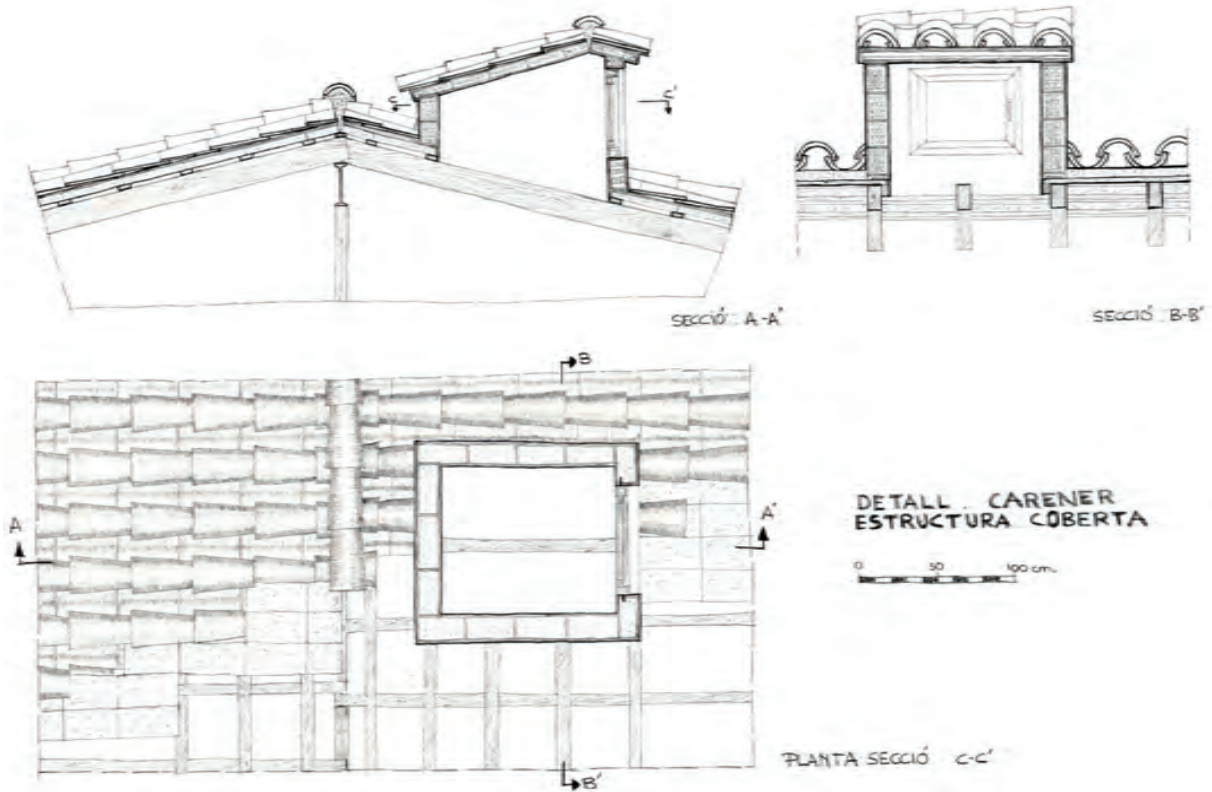

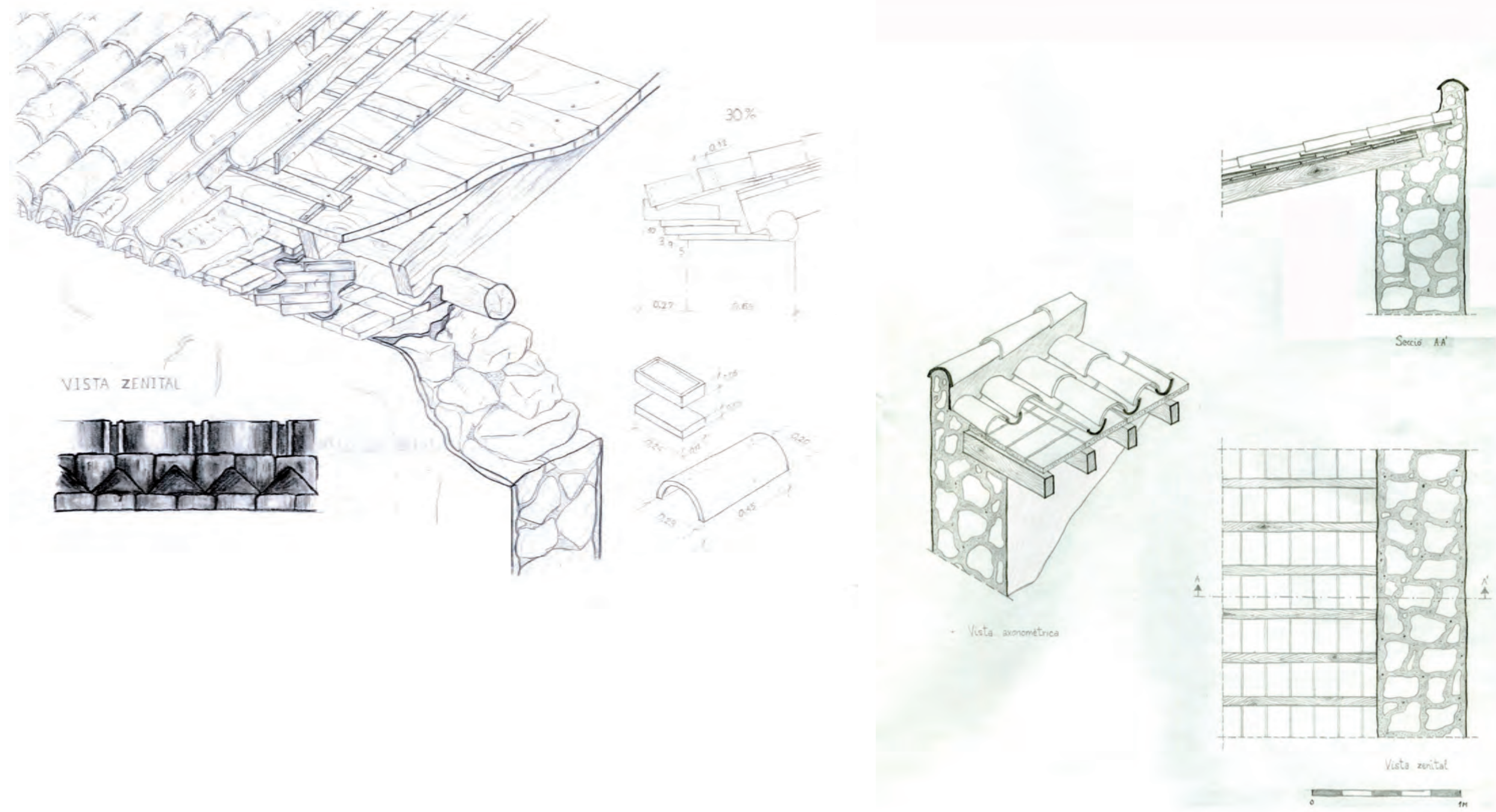


\section{Revestiments verticals}

Tradicionalment, en l'arquitectura popular l'aplicació d'un revestiment sobre els paraments exteriors ha sigut motivada per la protecció que li confereix al material constituent, afavorint la durabilitat de la fäbrica enfront dels agents atmosfèrics, i no tant com a pretensió decorativa, encara que en nombroses ocasions ha sigut el suport d'acabats decoratius.

Els arrebossats, normalment fets amb morter de calç, podien cobrir, amb major o menor aplanament, completament els paraments. De vegades, només les zones pròximes a les juntes entre pedres de paredar, visualitzant-s'hi parcialment. També es troben fàbriques amb les juntes enrasades, limitant-se els revestiments als emmarcats dels vans de la casa.

Els morters d'algeps també s'han emprat ben sovint, particularment en les zones on la matèria primera és abundant, ja que aquest era un algeps de gra gros resistent a la humitat.

En edificacions antigues que no han tingut manteniment, el revestiment ha arribat a tal punt de deteriorament que ha desaparegut per complet i només una atenta mirada delata la seua anterior existència.

Els emblanquinaments, com a acabat últim del recobriment d'una construcció, poden observar-se de forma completa en nombroses construccions i també en algunes de forma parcial en els perímetres de finestres. L'aplicació de la calç per a emblanquinar està relacionada amb la higiene, per la desinfecció que aporta la calç viva. L'emblanquinat pot aplicar-se entonat amb l'addició a la beurada de calç d'algun pigment mineral, sent habitual el tradicional blavet.

Els estucats són un tipus de revestiment decoratiu propi de construccions representatives i per tant menys comú que els anteriors. És un revestiment molt prim, de l'ordre de $3 \mathrm{~mm}$, amb una dosificació molt controlada amb àrids de fina granulometría, podent-se aplicar en una o vàries capes.

Cc) Juan A. Garcia Esparza - ISBN: 978-84-695-8048-6

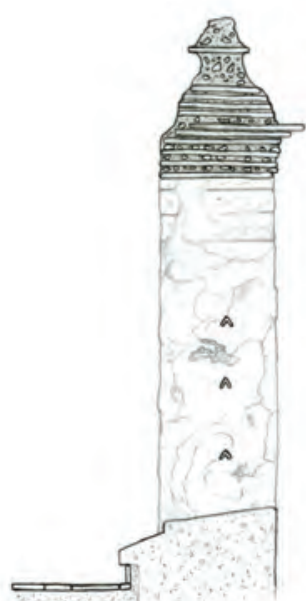

SECCIO
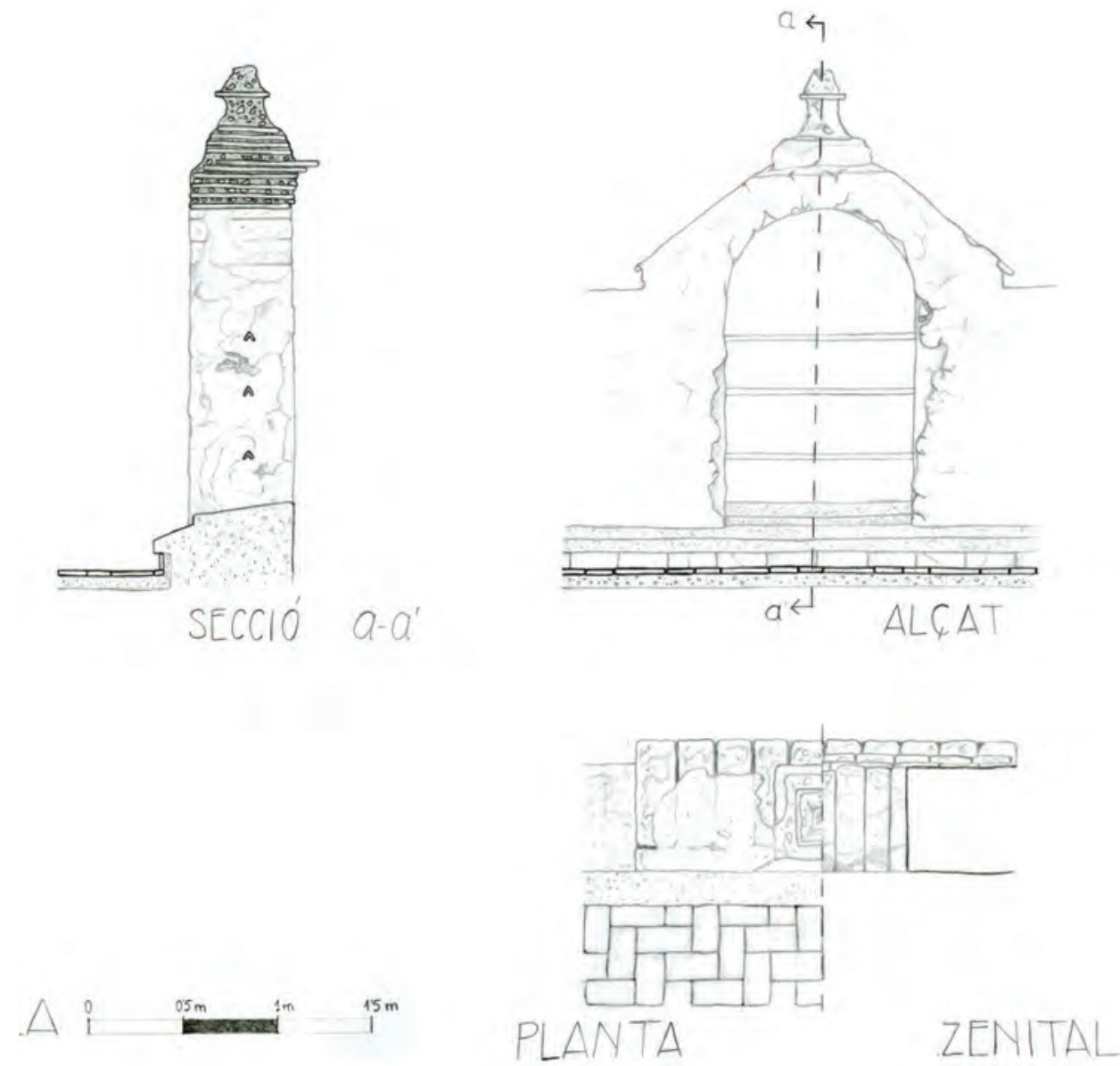


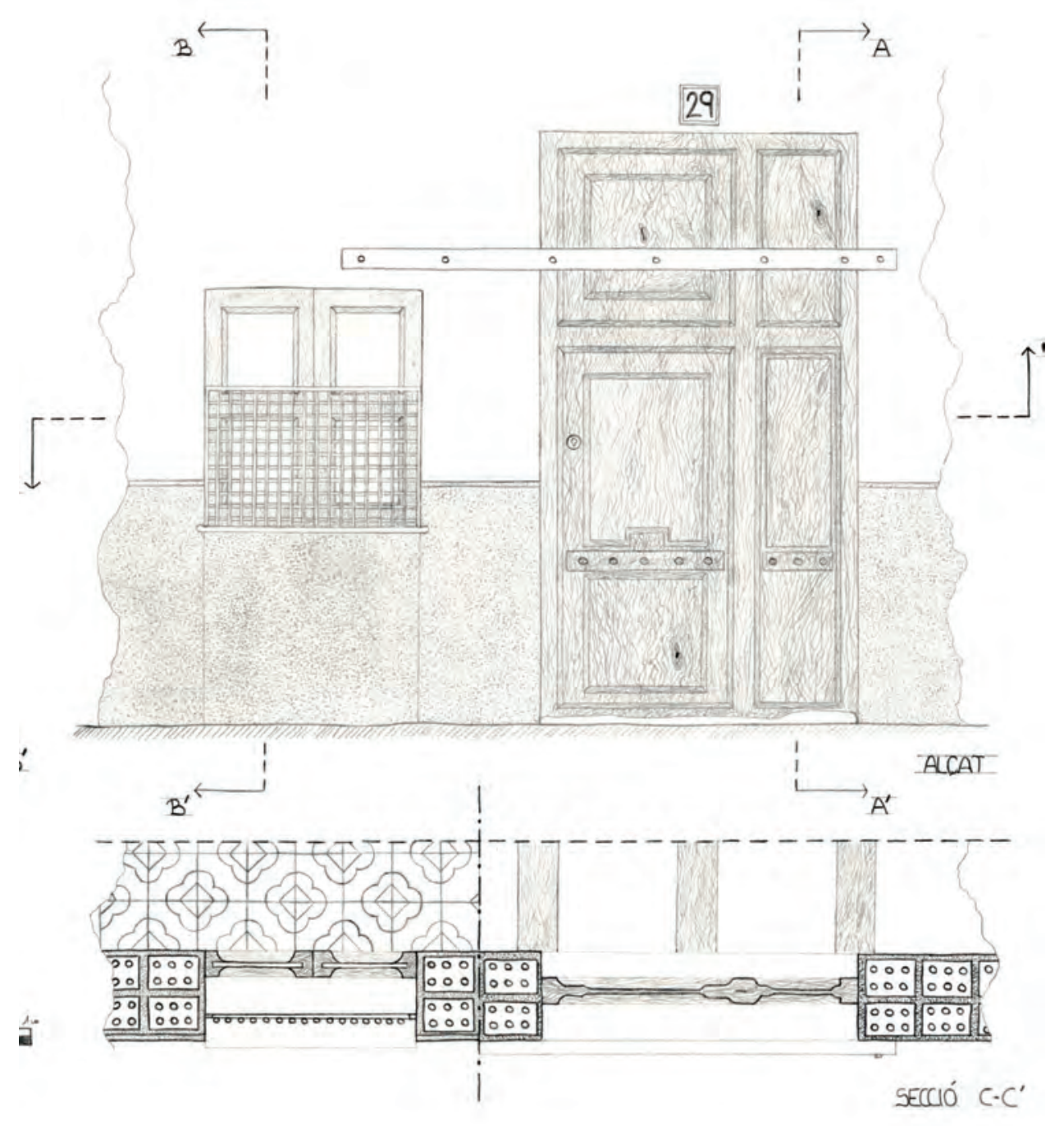

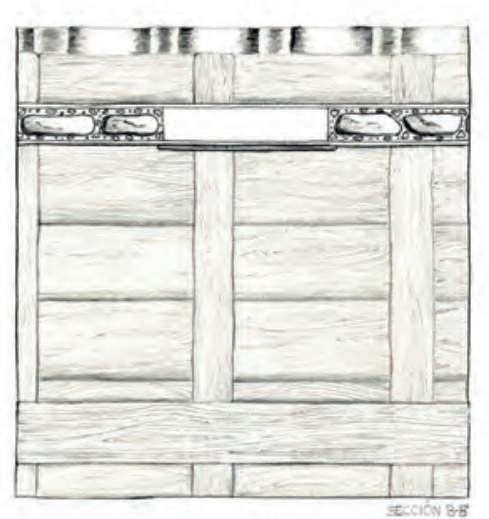
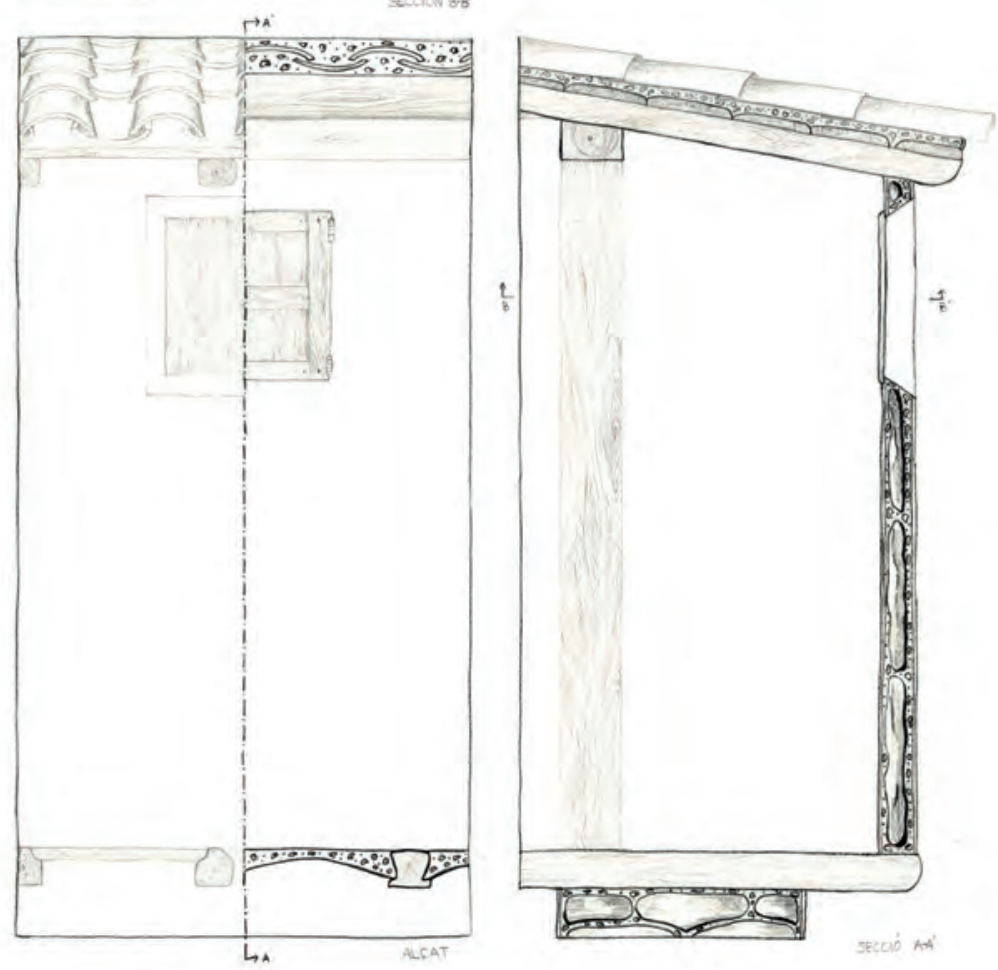


\section{Revestiments horitzontals}

En la planta baixa, en la part destinada a l'habitatge, els paviments se solien realitzar amb una argamassa composta de morter de calç amb un afegit de graveta i guix que s'estenia sobre la terra prèviament compactada. L'acabat, si estava correctament executat, era llis i impermeable, perquè es finalitzava aplicant sobre l'argamassa quasi endurida un enlluït de calç, guix i un poc d'arena fina, a manera de brunyit. Aquest sistema, conegut per trespol a les nostres terres, és un vocable que ha acabat per estendre's per a denominar qualsevol paviment d'un habitatge.

Als domicilis els propietaris dels quals fruïen d'una sanejada situació econòmica eren habituals els sòls de quadrons col-locats sobre un llit de morter de calç. A les cases més humils era freqüent recórrer a la terra compactada mesclada amb una petita quantitat de calç.

Als vestíbuls, les zones d'accés i als espais destinats als animals, el més habitual era el paviment de còdol de riu (empedrat) tan característic en carrers i cases dels nostres pobles, així com els enllosats de pedres amb formes més o menys regulars, i també la terra compactada.

En les plantes altes el més usual era el trespol, un paviment de quadrons, o simplement una estesa de morter de calç allisat amb el remolinador o una plana, solució, aquesta última, que solia estendre's als paviments de les plantes superiors, particularment en la falsa o sota la coberta.

El taulell ceràmic va ser molt utilitzat a finals del segle XIX i principis del Xx, especialment el tradicional de tonalitats roig i blanc. En generalitzar-se la manufactura es van diversificar els colorits i les decoracions. Avui es poden trobar multitud de tipus de paviments, des del taulell ceràmic al taulell hidràulic, generalitzat també a principis del segle xx. L'execució de l'enrajolat es realitza per mitjà de l'estesa d'una capa de $3-5 \mathrm{~cm}$ de regularització a base d'argamassa de calç, per a col·locar-hi posteriorment els taulells amb morter.

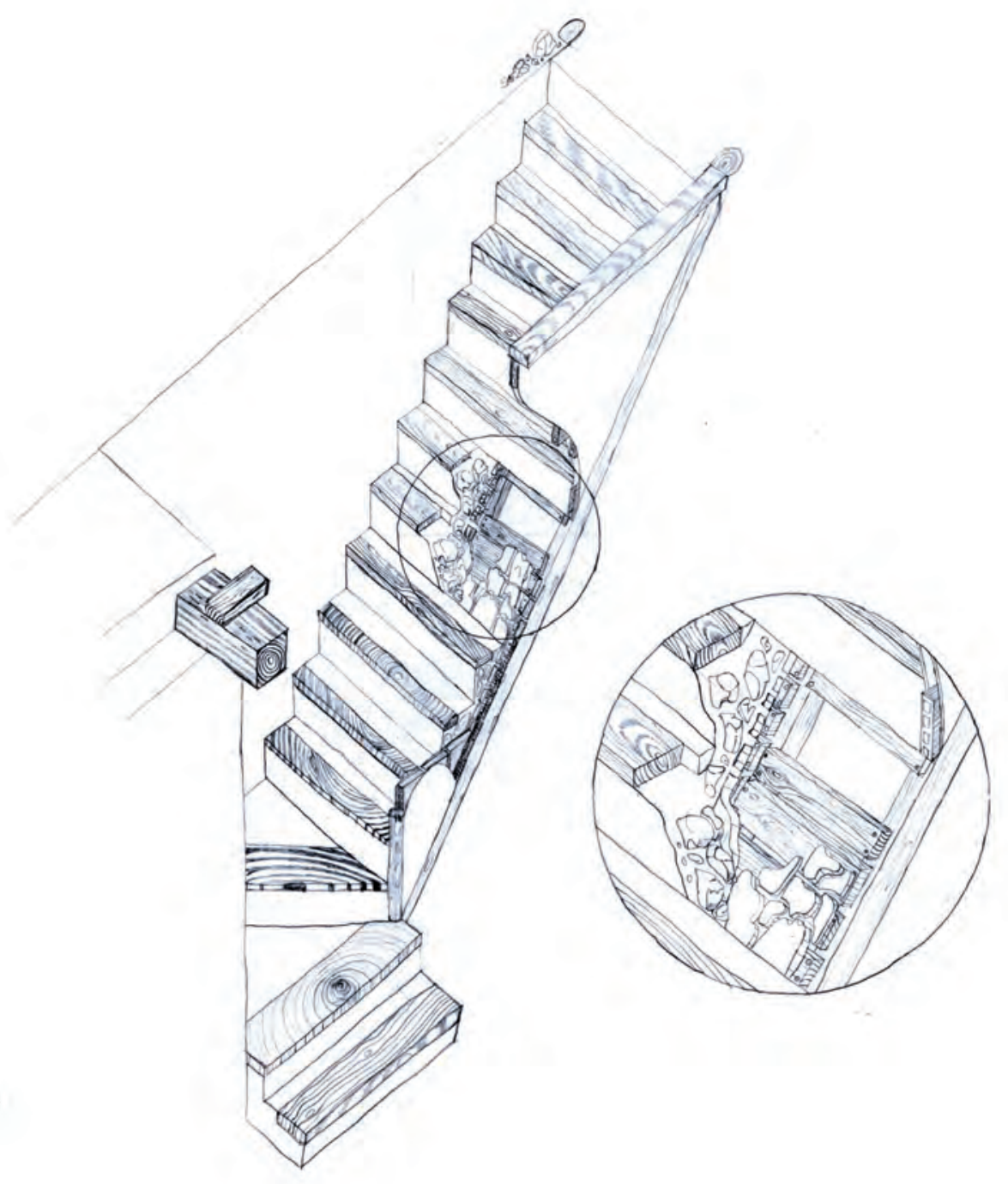

Construcció I, projecte. La mirada i reflexió sobre les tècniques constructives tradicionals - UJI - DOI: http://dx.doi.org/10.6035/Sapientia78 

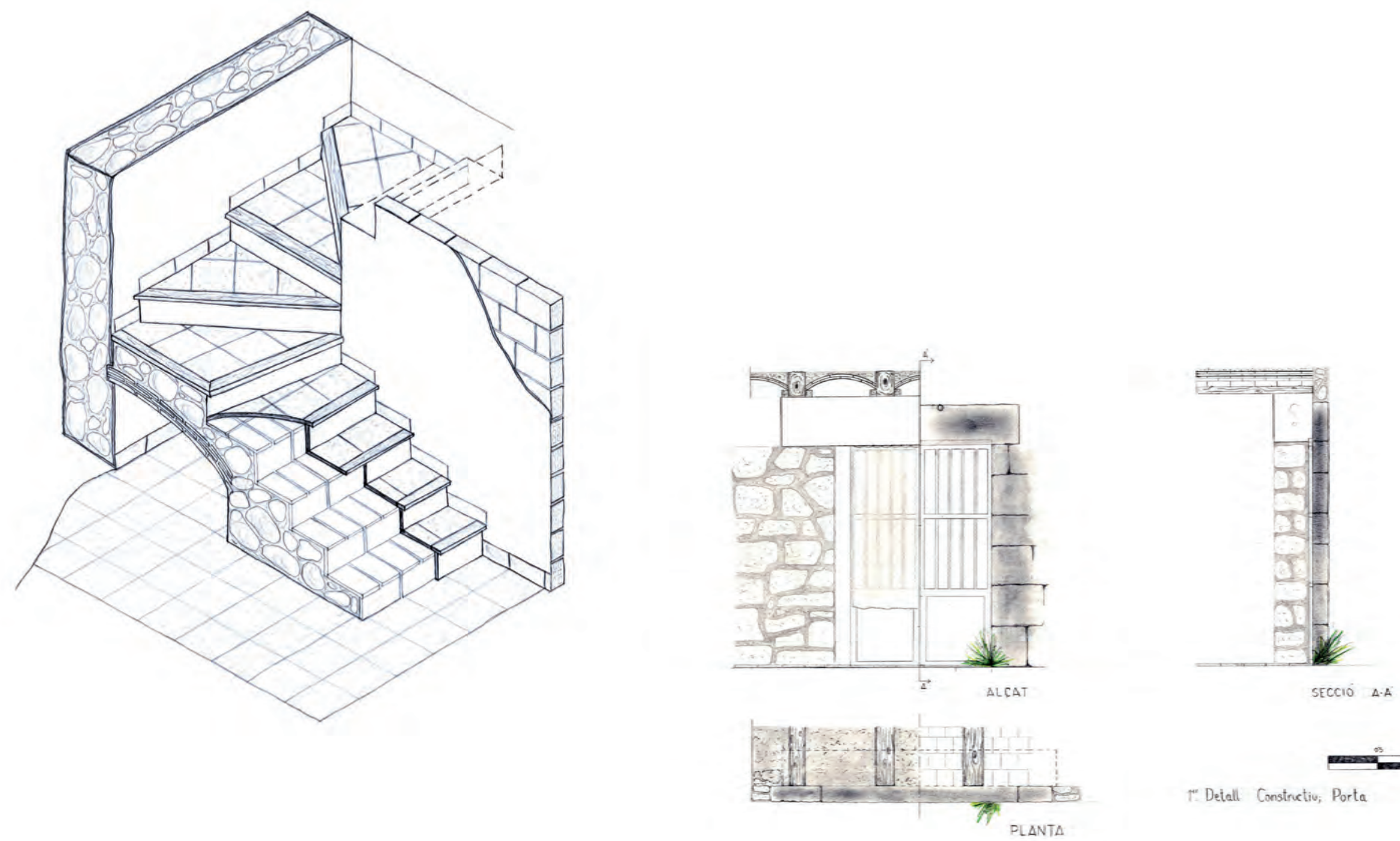

T* Detall Constructiv; Port 


\section{Elements singulars}

\section{Xemeneies}

La xemeneia es compon de dues parts, la llar, on es produeix la calor per a l'habitatge, i el tiratge de la mateixa xemeneia, l'element constructiu pel qual circula el fum provocat en la llar fins a eixir a l'exterior.

La tipologia de la llar central, més pròpia de les cases més antigues, no és la més habitual. La que podem trobar a les nostres comarques és l'adossada a un parament, fins i tot provocant una cavitat en el mur perquè el fum ixca directament en la mateixa vertical i a través d'una campana troncocònica que afavorisca el seu ascens fins a l'exterior.

Tant la campana com el tiratge en tot el seu traçat, són construïts amb materials lleugers i normalment plans, lloses de pedra o rajoles, aparellats amb morter de calç o algeps i recolzats sobre els elements resistents de la construcció, els forjats i la coberta.

El tiratge sol ser prismàtic, propi de les llars situades en un lateral de la planta, i els fumerals poden aparèixer en la coberta pròxims a la mitgera, a mig pendent i també a la vora del ràfec.

Per les seues dimensions, esveltesa i varietat, sobretot en la forma del seu coronament superior, és un dels elements que sempre ha sigut característic de la diversitat de la construcció tradicional. Normalment, les cavitats en els murs s'han executat «a sentiment», és a dir, sense estudis tècnics sobre la transmissió d'esforços o la seua capacitat portant. Aquestes cavitats, normalment situades en la planta baixa o en la primera, no sols s'han emprat per a albergar la llar d'un foc, sinó també per a col-locar els prestatges necessaris per a l'activitat de la cuina, lloc on es disposava la llar en la casa popular.

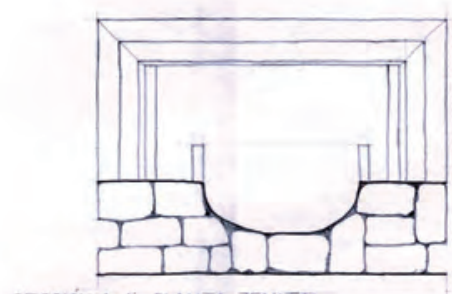

SECCIO A.A' PLANTA ZENITAL

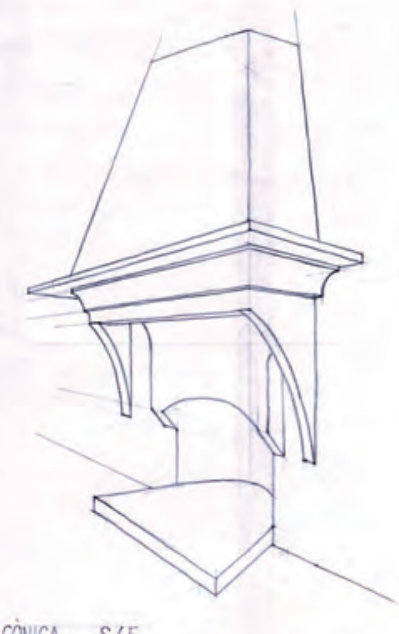

E. $1 / 20$

CONICA S/E
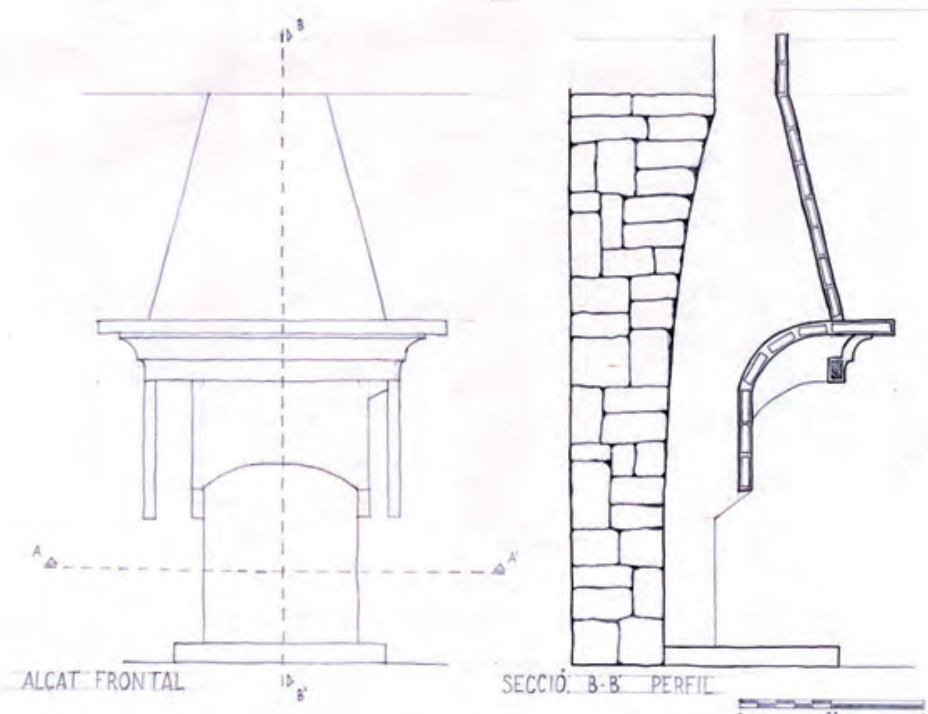


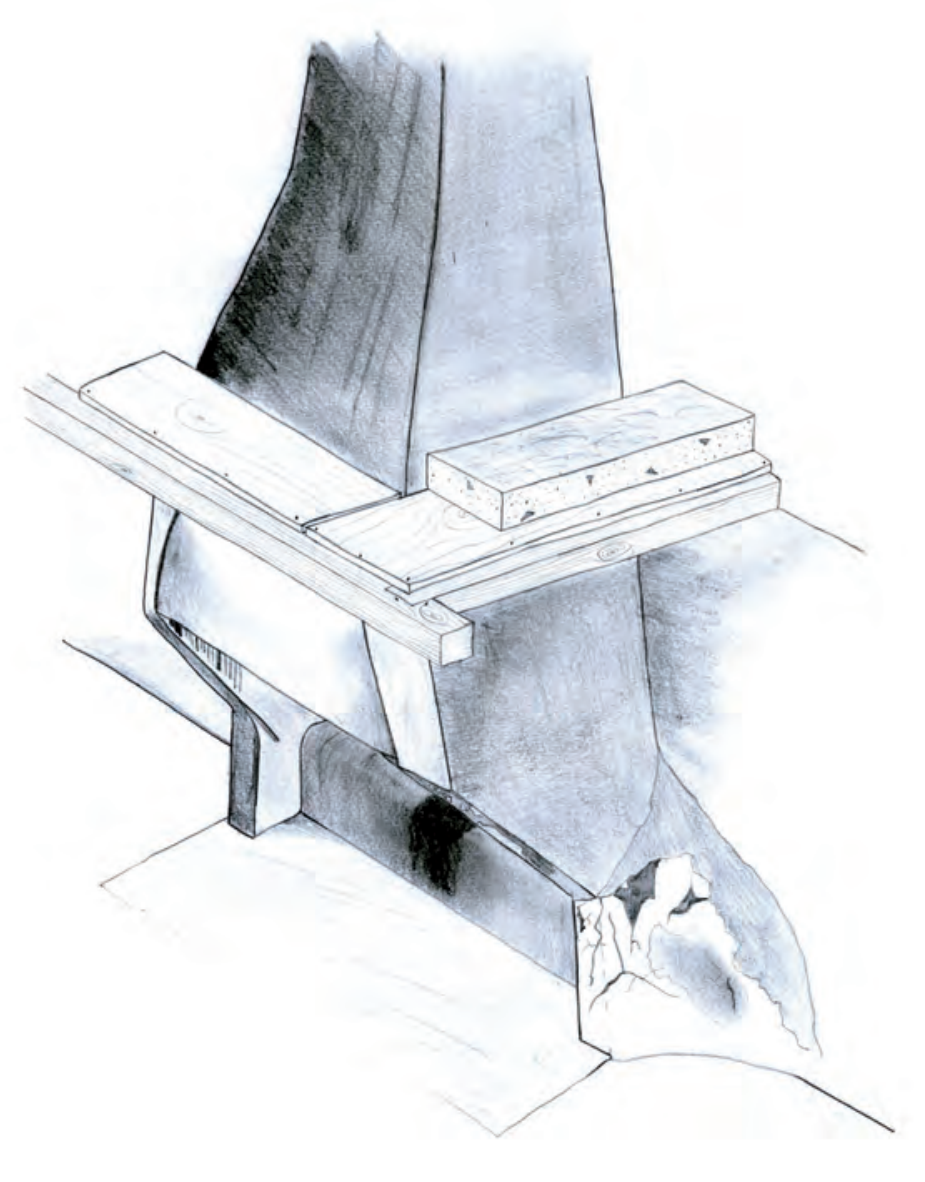

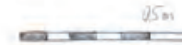
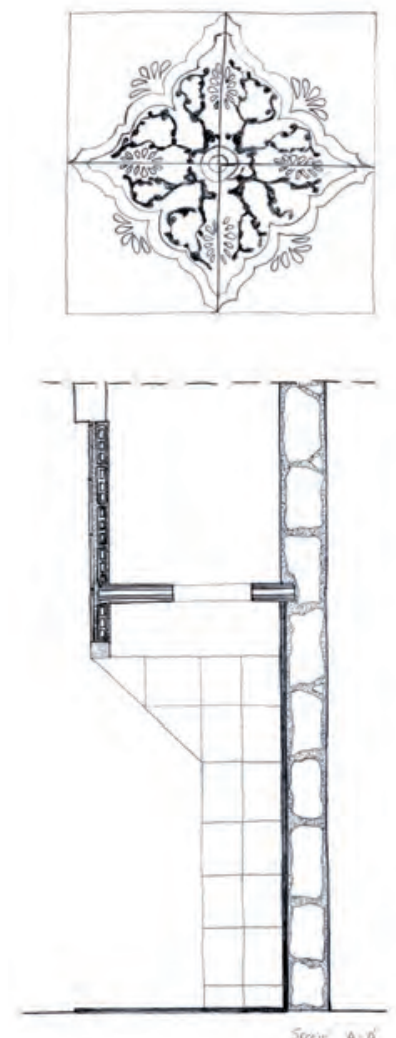

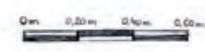
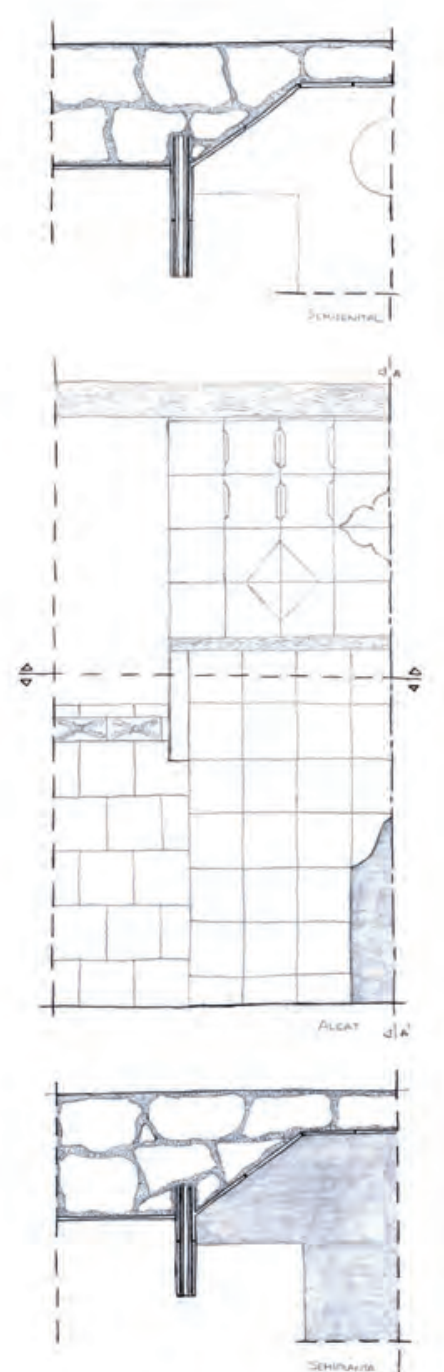


\section{Bibliografia}

Biarge, F., Biarge, A. (eds.) (2001): Casa por casa. Detalles de arquitectura rural pirenaica. Huesca.

Font, F., Hidalgo, P. (2009): Arquitecturas de tapia. Castellón. CoAat.

Heyman, J. (1995): Teoría, historia y restauración de estructuras de fábrica. Madrid. ETsAm. Instituto Juan de Herrera.

Heyman, J. (1999): El esqueleto de piedra. Mecánica de la arquitectura de fábrica. Madrid. ETsAm. Instituto Juan de Herrera.

HuerTa, S. (2004): Arcos, bóvedas y cúpulas. Geometría y equilibrio en el cálculo tradicional de estructuras de fábrica. Madrid. Etsam. Instituto Juan de Herrera.

Nourissier, G. et al. (2002): Arquitectura tradicional mediterránea. Avignon. École d'Avignon.

Regalado, F. (1999): Los forjados de los edificios: pasado, presente y futuro. Alicante. Cype Ingenieros.

Rodríguez Ortíz, J. M. et al. (1996): Curso aplicado de cimentaciones. Madrid. COAM.

Truñó, Á. (2004): Construcción de bóvedas tabicadas. Madrid. Etsam. Instituto Juan de Herrera.

\section{Autoria dels dibuixos}

\section{Fonaments}

David Moreno Estupiña

$2008 / 2009$

Lucía Cabedo Vicente

$2008 / 2009$

Rubén Senar Lluch

$2009 / 2010$

Murs. Esforços

Murs. Carreuat

Carlos Sánchez Trujillo 2009/2010

Ivan Tárrega Saura 2008/2009

Fernando Gargallo Salvador 2008/2009

Murs. Maçoneria

\begin{tabular}{ll}
\hline Alba Bermejo Sancho & $2008 / 2009$ \\
Berta Llop Sebastiá & $2010 / 2011$ \\
Paula Pérez García & $2008 / 2009$
\end{tabular}

Murs. Carreuat-Maçoneria

David Santos Mahillo 2009/2010

Juan Torres Bueno 2010/2011

Albert Piñas Font 2008/2009

Murs. Maó i tova

Sergio Rodríguez Ariño 2008/2009

Ana Salvador Vives 2008/2009

David Ruiz Ferré 2008/2009 
Muros. De tàpia i tova

Obertures. Finestra

Pedro Ventura Henares

Alejandra Miguel Escrig

$2009 / 2010$

2010/2011

$2009 / 2010$

Obertures. Porta

Rubén Bel Traver

$2009 / 2010$

Paula López Burdeos

Bárbara Álvarez Vázquez

Obertures. Balcó

Andrés Felius Albalat

Nerea Tena Escrig

Daniel Orts Moya

$2009 / 2010$

$2010 / 2011$

2010/2011

Arcs i voltes de carreuat. Arc

Josep Casanova Villalonga

Lucía Cabedo Vicente

Borja Ferrandis Franch

$2009 / 2010$

$2008 / 2009$

$2009 / 2010$

Arcs i voltes de carreuat. Volta

Julián Rodríguez Comins

José Miguel Olea Catalán

$2008 / 2009$

$2008 / 2009$

Ferran Escalada Beltrán
Arcs i voltes de maó. Empentes i resistències

Arcs i voltes de maó. Arc

Félix Martínez Nadal 2008/2009

Sheila Irene Parreño 2008/2009

Pedro Vinagre Fernández 2009/2010

Arcs i voltes de maó. Volta

Lorena Edo Rull 2008/2009

Arcs i voltes de maó. Revoltó

Rubén Senar Lluch 2009/2010

Lorena Edo Rull 2008/2009

Vanesa Edo Escrig —2010/2011

Arcs i voltes de maó. Volta d'escala

Sergio Rodríguez Ariño 2008/2009

Sheila Irene Parreño 2008/2009

Pedro Vinagre Fernández 2009/2010

Cristian Miravet Aibar 2010/2011

Daniel Orts Moya 2010/2011

Arcs i voltes de maó. Cúpula

David Moreno Estupiña 2008/2009

Entremats lignis. Forjat

Juan Carlos Sáez Ibáñez 2009/2010

Sergio Traver Monterroso $\quad 2010 / 2011$

Alexis Chumillas Mateu 2010/2011 
Entremats lignis. Escala

Isidro Sánchez Heras

Joaquín Aleixandre Albiol

David Santos Mahillo

Entremats lignis. Coberta - Aiguavés

Emilio Fuentes García

Josep Casanova Villalonga

Diego J. Basco Clausell

$2009 / 2010$

2010/2011

Entremats lignis. Coberta - Ràfec

\begin{tabular}{ll}
\hline Berta Llop Sebastiá & $2010 / 2011$ \\
Rubén Bel Traver & $2009 / 2010$ \\
Juan Torres Bueno & $2010 / 2011$
\end{tabular}

\section{Cobertura}

Pedro Vinagre Fernández

David Moreno Estupiña

$2009 / 2010$

Joaquín Marco Pastor
Revestiments verticals

Manuel Cano Gómez

$2008 / 2009$

Bárbara Álvarez Vázquez

2010/2011

María Orenga Izquierdo

2010/2011

Revestiments horitzontals

Miguel Martí González 2010/2011

Susana Aparicio Lara 2010/2011

Alberto García Ortega 2009/2010

Elements singulars. Xemeneies

Ramón Casas Manteiga 2009/2010

Joaquín Aleixandre Albiol 2010/2011

Vanesa Edo Escrig

$2010 / 2011$ 